\title{
الظروف المحتفة بالخطاب الشرعي وأثرها في تأويل النصوص
}

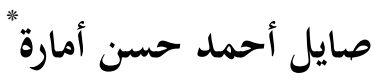

\section{الملخص}

ينـاقش هـذا البحــث العلاقـة بـين الخطـاب الشـرعي والظـروف المحتفـة بـه حسين صـدوره، وأثنر ذلك في تأويـل

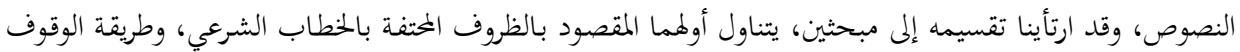

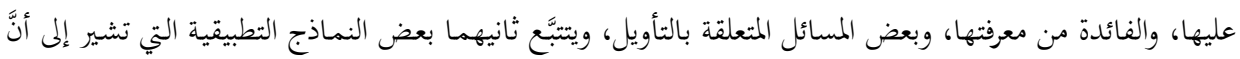
الظروف المحتفة بالخطاب الشرعي هي من أدلة التأويل؛ ما يعني وجوب استحضارها في عملية الاجتهاد لكيلا يجافي الحكم المستنبط مقاصد المشرِّع. الكلمات المفتاحية: الظروف المحتفة، تأويل النصوص، الخطاب الشرعي، مقاصد المشرع.

\section{Circumstances Surrounding Legislative Discourse and Their Effect on the Interpretation of Religious Texts}

\begin{abstract}
This article discusses the relationship between religious discourse and its surrounding circumstances and how such circumstances influence the issuing of rulings and the interpretation of religious texts.

The article is divided into two parts; the first deals with the meaning of the surrounding circumstances, the importance and benefits of their identification, and some issues related to interpretation. The second part provides some practical examples about how the circumstances surrounding religious discourse are considered evidence of interpretation. Accordingly, these circumstances should be taken into account in the process of Ijtihad, to ensure that the derived ruling is in line with the purposes (Maqasid) of Shariah.
\end{abstract}

Keywords: Surrounding Circumstances, Text interpretation, Legislative discourse, Maqasid al-Shariah.

$$
\text { ن ت دكتوراه في الفقه الإسلامي وأصوله، الجحامعة الوطنية الماليزية، أستاذ مساعد في كلية الشريعة، جامعة النجاح الوطنية، }
$$




\section{مقدمة:}

إنَّ النصوص الشرعية لمُ تنزل في فراغ، وإنَّاّ نزلت في سياق منظومة اجتماعية، لتؤثِّ

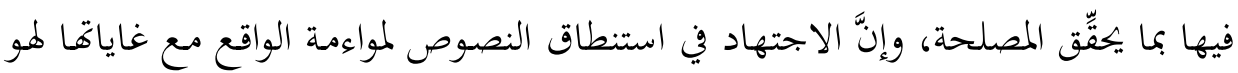

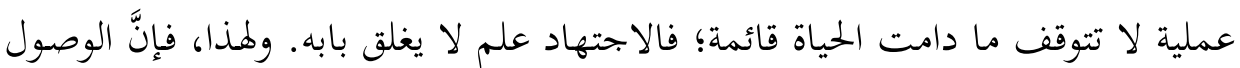

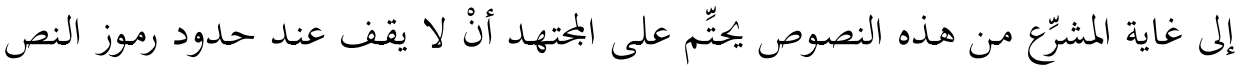
اللغوية فحسب، بل ينفذ إلى روحه المهيمنة عليه؛ وهي تحقيق المصلحة.

وفي المقابـل، فـإنَّ النظـرة الظاهريـة إلى النصـوص، وإغفــال المقاصــ التي قيلـت مـن أجلهـا، والظـروف المحتفـة بهـا، والاعتمـاد فقـط على الرمـوز اللغويـة في التعبير عـن مـراد الشـارع؛ كل ذلك يُنشِئ فقهاً متناقضـاً، وذلك بـالخروج ببعض النصوص مـن ظروفها الخاصة إلى فضاء العموم والإطلاق، فيترتَّب على ذلك تناقض مع النصوص الأخرى التي لتحني

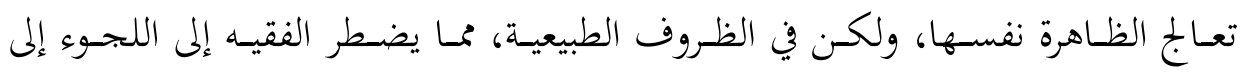
النسخ، والغلو فيه أحياناً.

لقد أبدع فقهاؤنا حين اهتموا بأسباب النزول على مرّ التاريخ الإسلامي، وأقروا بأنَّ

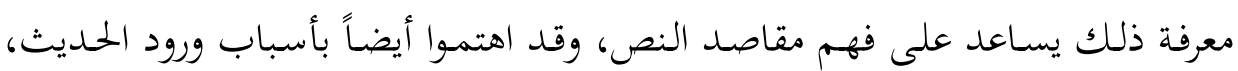
ولكن بصورة أقل. أمَّا الظروف المحتفة بالخطاب الشرعي فلم تلقَ منهم الاهتمام اللافت، بالرغم من الإقرار بوجود بعض الاهتمام. وتأسيساً على ذلك، فقد جاء هذا البحث للإجابة عن السؤالين الآتيين: 1. هل لمعرفة الظروف المحتفة بالخطاب الشرعي أثر في فهمه؟ r. هل تُعَدُّ الظروف المحتفة بالخطاب دليلاً من أدلة التأويل؟ ولإجابة عن هذين التساؤلين، فتـد قُسِم البحثث قسمين؛ الأول: الظروف المحتفة

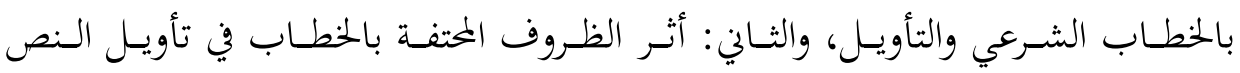




\section{ويهدف البحث إلى الوقوف على حقيقتين اثنتين، هما:}

ا ـ بيان مراعاة الإسلام الظرف الاجتماعي للمككلفف عند تشريع الأحكام ابتداءً. r. التأصيل لمفهوم الظرف الاجتماعي بوصفه دليلاً من أدلة التأويل.

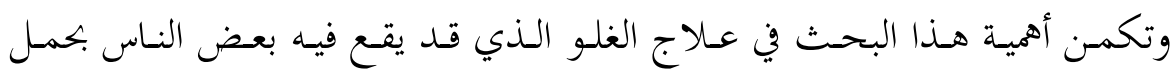
نصوصٍ جاءت لعلاج ظرف معين، وتنزيلها على واقع المسلمين بصورة مطلقة، من دون الانتباه إلى الظرف الاجتماعي الذي قيل فيه النص، والذي يقصر عليه النص فحسب. ثمة دراسات تعرَّضت لهذا الموضوع، ومن أهمها:

1. "القرائن والنص: دراسة في المنهج الأصولي في فقه النص"، للدكتور أيمن صالح. أصَّل الباحث للنظرية العامة للقرائن وأثرها في فقه النص، فقسّم القرائن من حيث تأثيرها في النص إلى قرائن ثبوتٍ، وإحكامِ، وترجيحِ، ودلالةٍ. بعد ذلك انتقل

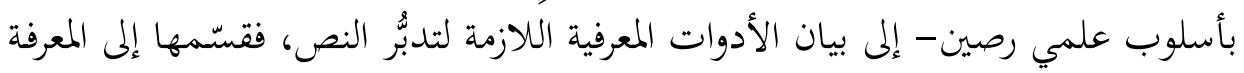

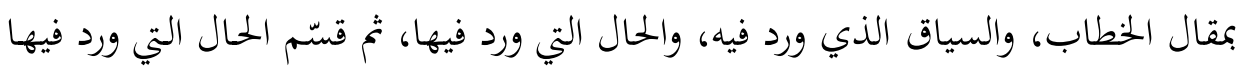

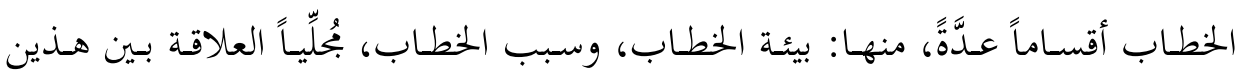
القسمين. وهـذه الجزئية الأخيرة هي التي اختص بهـا هـذا البحثث. ولأنَّ الباحثث تطرَّق إليها ضمن سياق النظرية العام، فقد غضّ الطرف عن الإسهاب فيها، ولا سيما الأمثلة

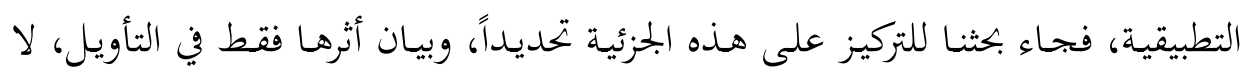
الدلالة بوجه عام. r. "فقه المقاصد: إناطة الأحكام الشرعية بمقاصدها"، للدكتور جاسر عودة. عمل الباحث في دراسته على التأصيل لفكرة علاج التعارض الظاهري بين النصوص بالإفادة من المقاصد الشرعية، وربط الأحكام الاجتهادية بهذه المقاصد. ويتفـق بحثي مـع هـــه الدراسـة في أنَّ الظروف المحتفـة بالخطـاب الشـرعي هي أحسد

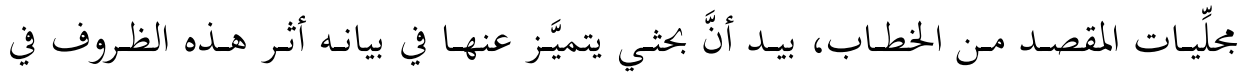




\section{أولاً: الظروف المحتفة بالخطاب الشرعي والتأويل}

\section{ا ـ تعريف الظروف المحتفة بالخطاب الشرعي وأهميتها:}

يقصد بالظروف المحتفة بالخطاب الظروف الاجتماعية التي كانت سائدة عند نشوء

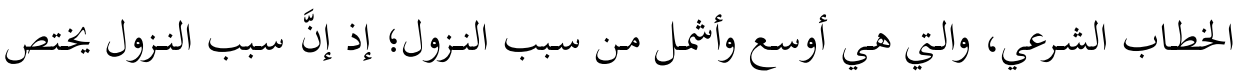

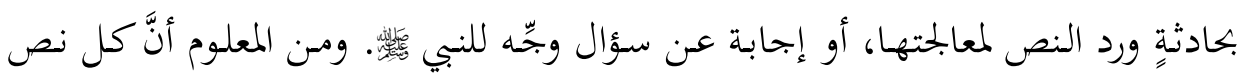

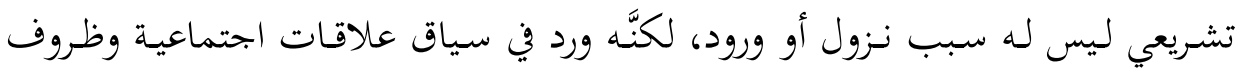
تاريخية وأنماط سلوك، بما في ذلك جميع العلاقات السائدة في حياة الناس زمن الننزيل. وبالمثل، فإنَّ الظرف الاجتماعي المحتفّ بالخطاب أوسع من العُرف؛ إذ يُعَدُّ العُرف أحد العناصر المكوّّنة لهذا الظرف. وهذذا، لا يصلح كل واقع اجتماعي أنْ يُسمَّى عُرفاً؛ فللعُرف ضوابطه مـ الاضطراد والأغلبية، وهو يستغرق وقتاً طويلاً لينشأ ويترسَّخ، وكل هذا لا يشترط في الظروف المحتفة بالخطاب. "إنَّ ما يجيط بالخطاب من أعراف سائدة، وقيم مستقرة، وأوضاع قائمة، وما اكتنف

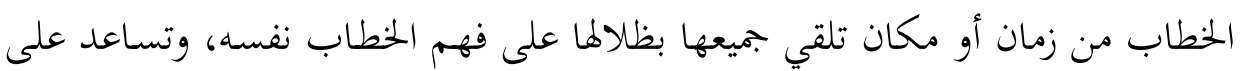

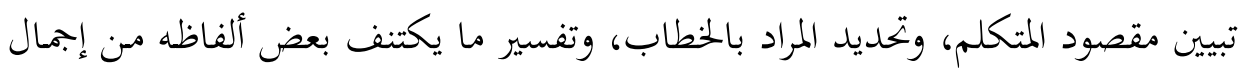

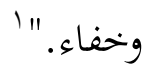

إنَّ أهـم غايـات الخطـاب الـديني هـي صـياغة الواقـع (حيـاة النـاس) بمـا يـوائم مـراد

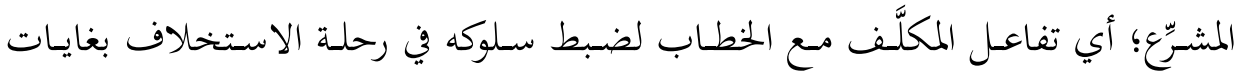

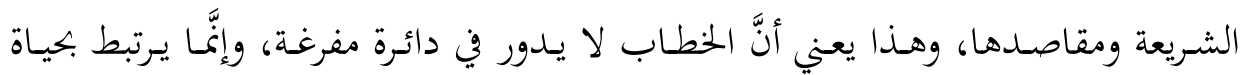

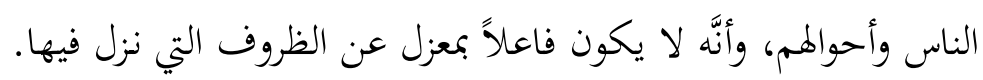
وإنَّ بتر الكالام وفصله عن الواقع الذي قيل فيه، والتعامل مع الخطاب في سياق

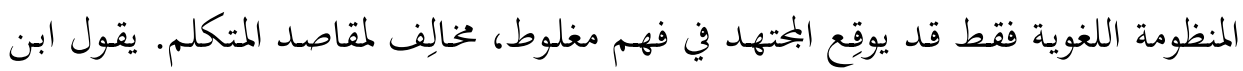
' الكيلاني، عبد الرحمن. "القرينة الحاليـة وأثرهـا في تبين علدة الحكىم الشـرعي"، المجلـة الأردنيـة في الدراسـات

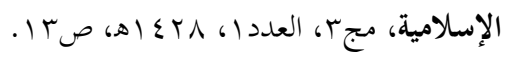




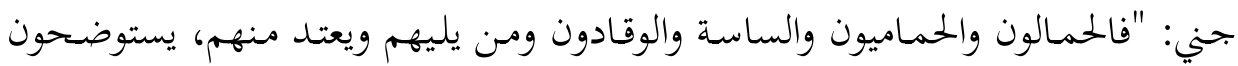

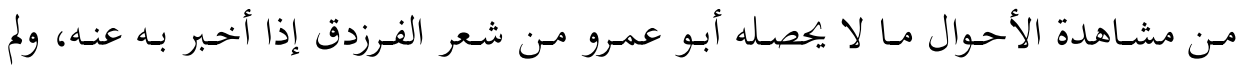

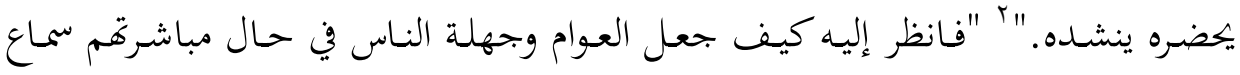

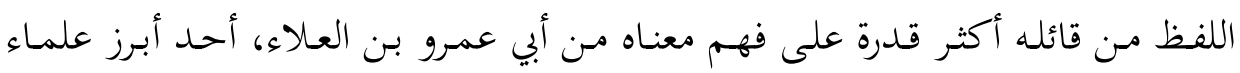

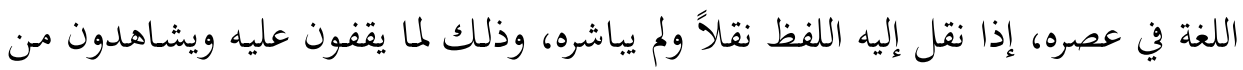

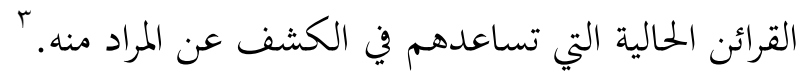

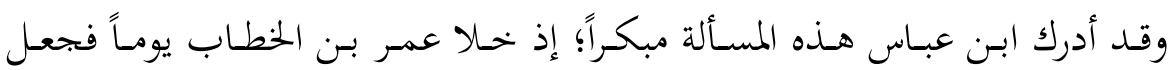

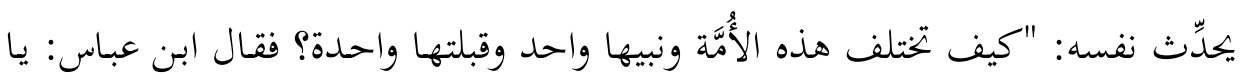

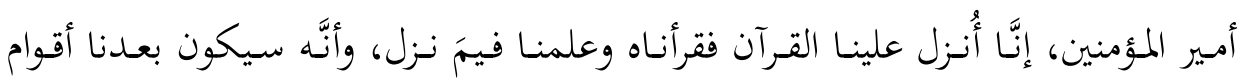

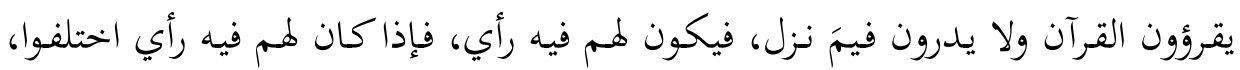

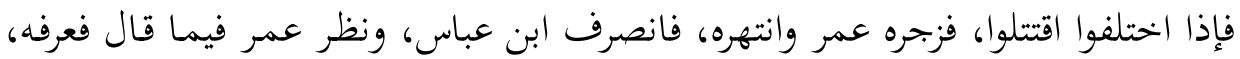

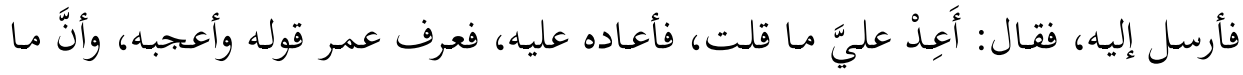

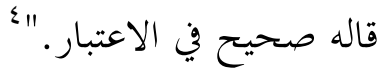

فإذا كان كلام ابن عباس مقتصراً على بيان أهمية معرفة سبب النزول فلا ريب أنَّ النّا

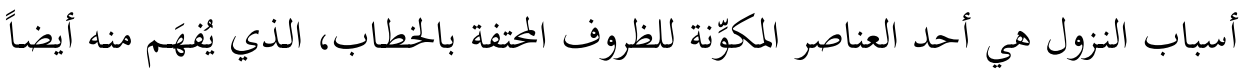

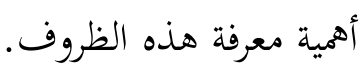

يقول الشاطبي: "إنَّ علم المعاني والبيان الذي يُعرف به إعجاز نظم القرآن، فضلاً

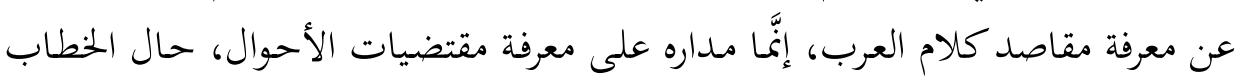

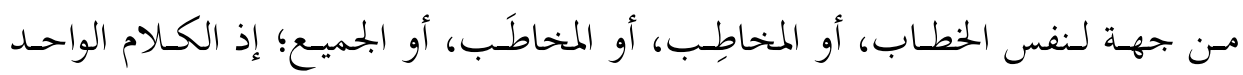

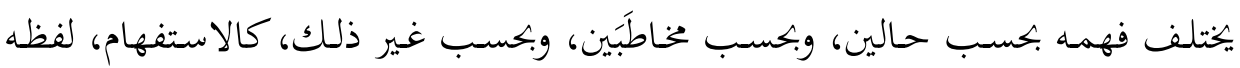

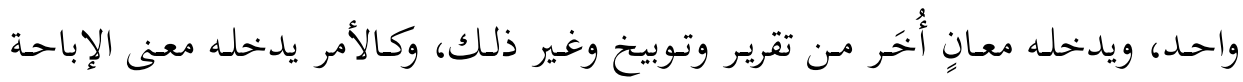

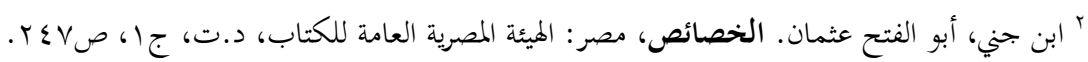

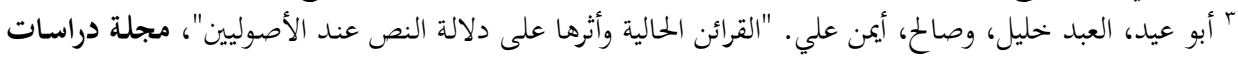

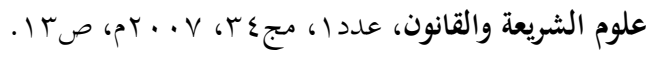

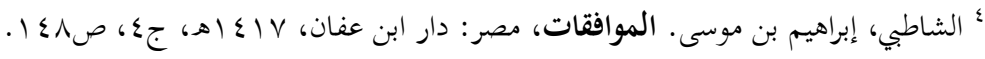


والتهديد والتعجيز وأشباهها، ولا يـدل على معناهـا المراد إلا الأمور الخارجـة، وعمدةقا

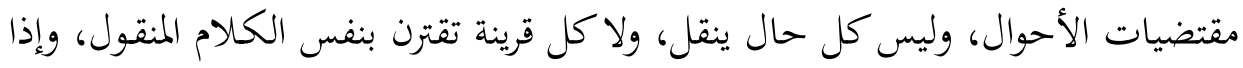

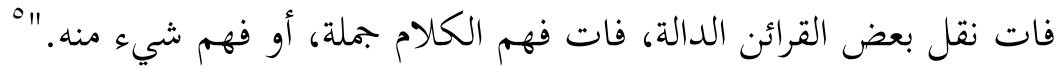

ويقول الشاطبي أيضاً في بيان الأمور التي تُعِين على تفسير النصوص: "ومن ذلك أفيك

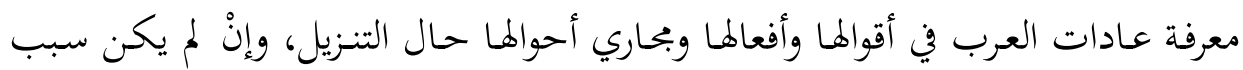

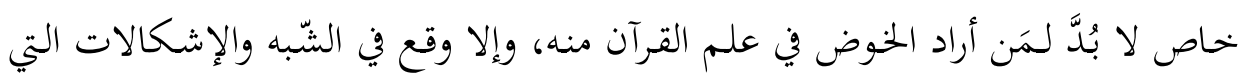

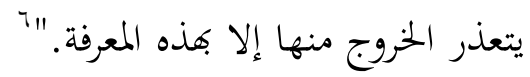

والحقيقة أنَّ مراعاة الظرف الذي قيل فيل فيه النص مـن أجل فهمهـ لا يعني تخصيصاً

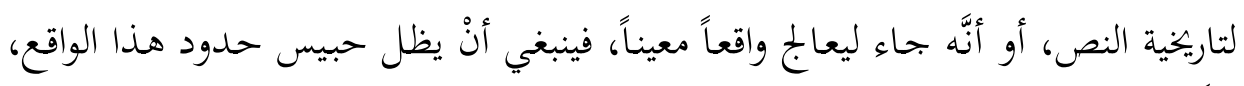

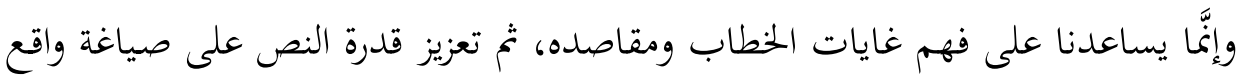

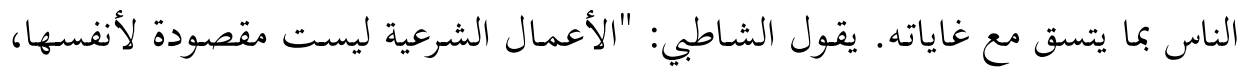

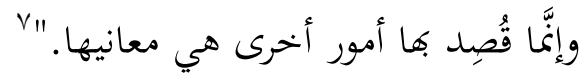

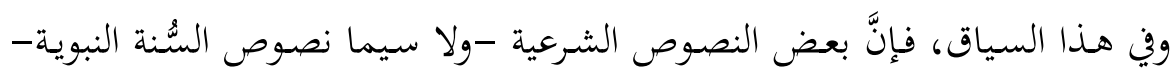

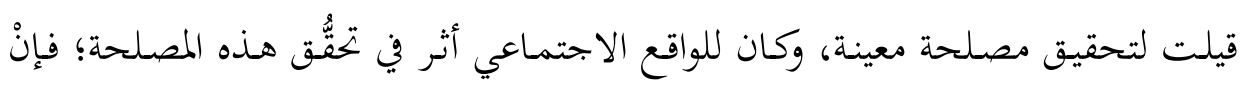

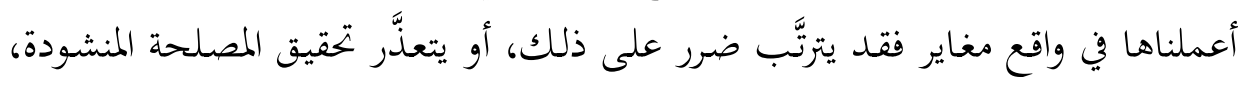

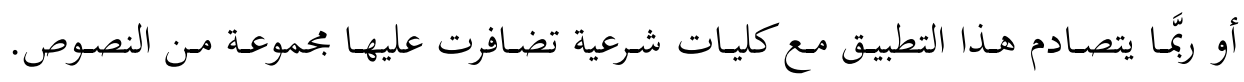

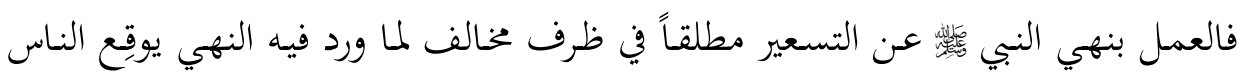

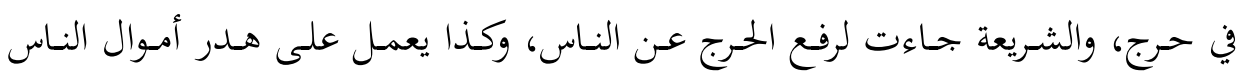

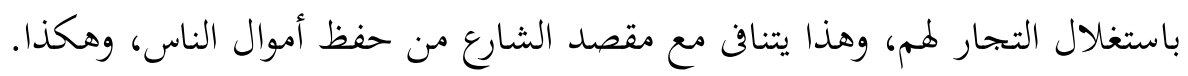

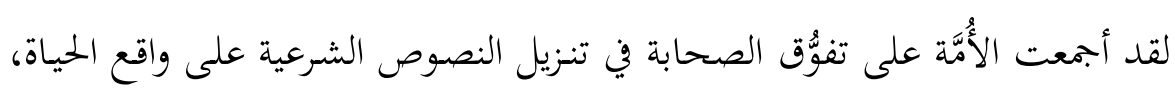

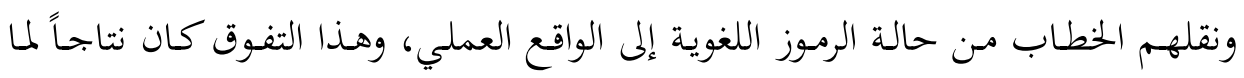

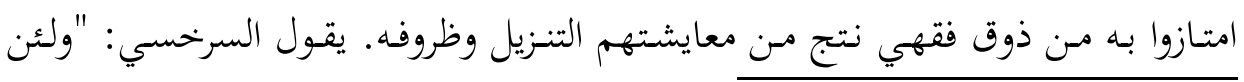

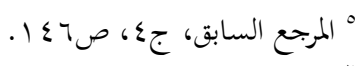

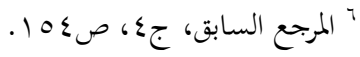

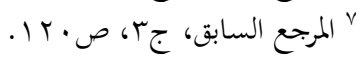


كان قوله (الصحابي) صـادراً عـن الرأي، فرأيهم أقوى مـن رأي غـيرهم، لأغنَّم شـاهدوا طريست رسـول الله النصوص، والمحال التي تتغير باعتبارها الأحكام، فبهذه المعاني سترجح رأيهم على رأي من ونس احت

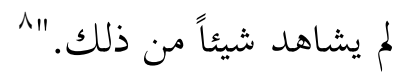

\section{Y . طرائق تعرُف الظروف المحتفة بالخطاب الشرعي:}

يمكن للمجتهد الوقوف على الظروف المحتفة بالخطاب الشرعي عن طريق الآتي:

أ. جمع النصوص التي تتحـدث عن ظـاهرة واحـدة. فالنصوص الشـرعية لا تعـارض

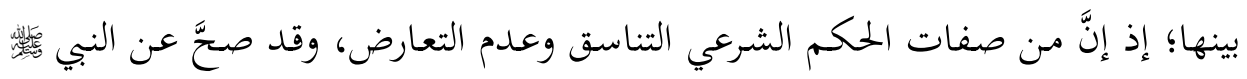

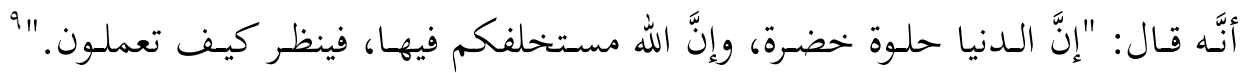

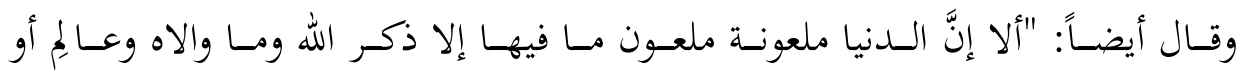

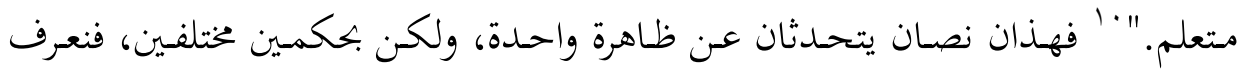
بذلك أنَّ كالا النصين يتحدث عن ظاهرة مختلفة. ب. تقصي النص الذي يرد فيه ما يدل على الظرف أو السياق خاصته. فقد صحَّ

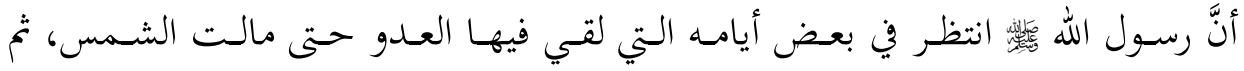

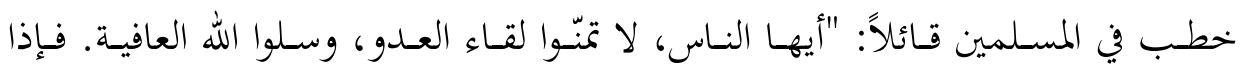
لقيتموهم فاصبروا، واعلموا أنَّ الجنة تحت ظلال السيوف. "'ا" فالسياق يدل على مناسبة

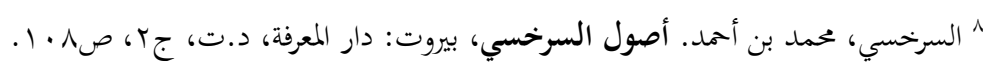

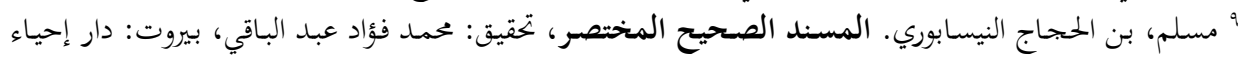

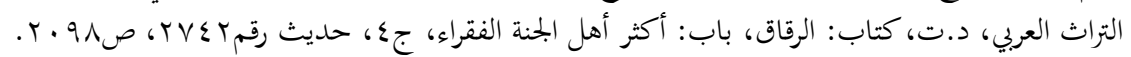

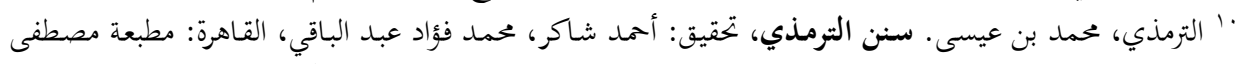

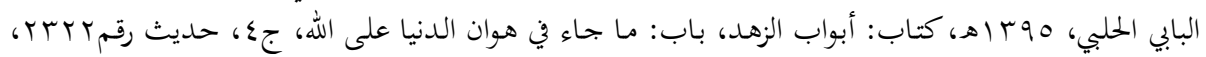

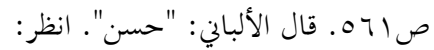

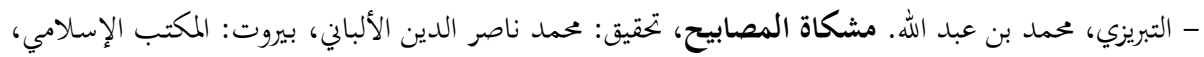
طr،

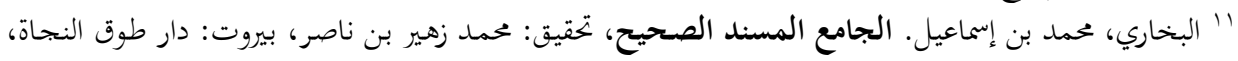

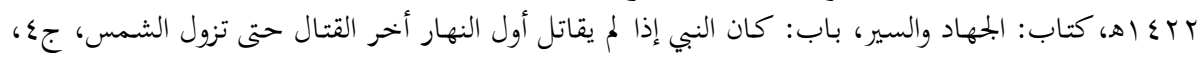




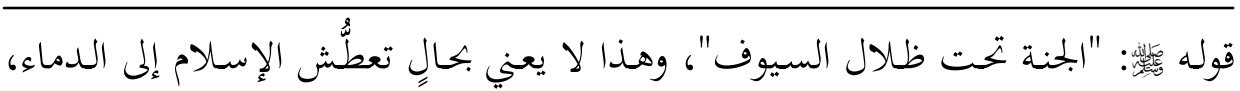
وإنَّا هو حديث ورد في سياق معين سنوضِّحه في سياق البحث إن شاء الله.

ت. ورود رواية صحيحة عن الصحابة تبيّن ذلك، مثل أسباب النزول. فعن مصعب بن سعد عن أبيه أنَّه نزلت فيه آيات من القرآن، قال: حلفت ورد أم سعد أنْ لا تكلمه أبداً حتى يكفـر بدينـه، ولا تأكل ولا تشـرب، قالـت : زعمْـتَ أنَّ الله وصـاك بوالـديك، وأنـا أمك، وأنا آمرك بهذا، قال: مكثت ثلاثاً حتى غشي عليها من الجهاب، فقام ابن لها يقال له عمارة، فسقاها، فجعلت تدعو على سعدٍ، فأنزل الله تعالى في كتابه العزيز هذه الآية:

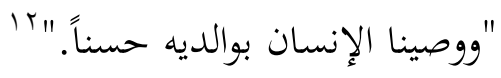

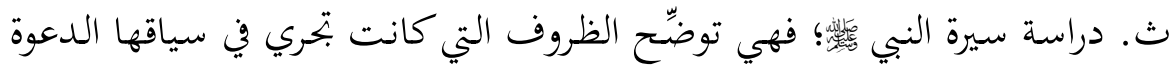

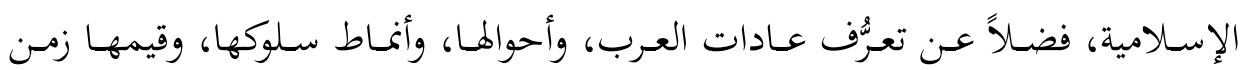

\section{r. فوائد تعرُّف الظروف المحتفة بالخطاب الثرعي:}

تتجلَّى أهمية تعرُّف الظروف المحتفة بالخطاب الشرعي فيما يأيت:

أ. تعرُّف الظرف العـام الذي قيل فيـه النص يمثِّل علاجـاً لظـاهرة الغلو في النسـخ.

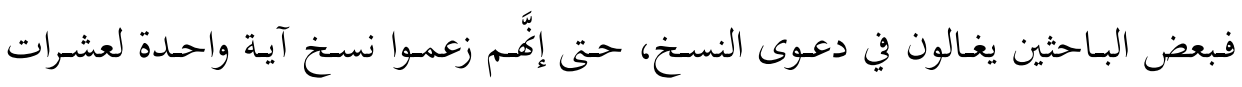

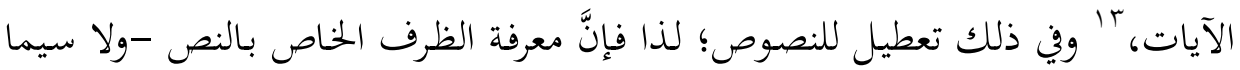
نصوص السُّة الشريفة- يساعد على إعمال النصوص التي قد تبدو متعارضة أول وهلة.

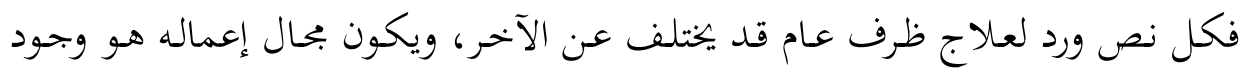
هذا الظرف، مثل في النبي فئس عن زيارة القبور، ثم إباحة ذلك. r' "مسلم، المسند الصحيح المختصر، مرجع سابق، كتاب: فضائل الصحابة، باب: في فضل سعد بن أبي وقاص،

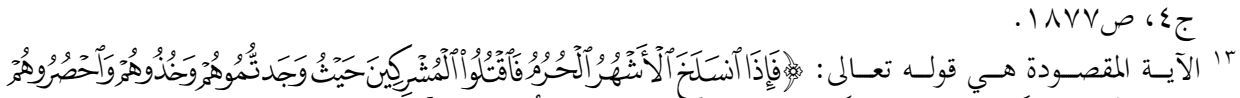

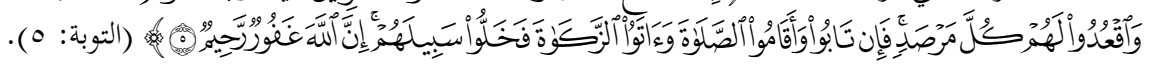

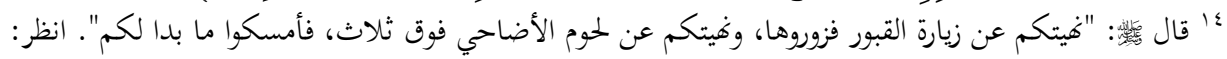




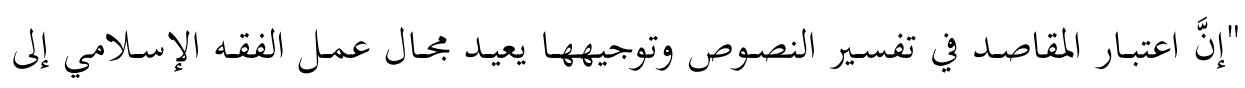

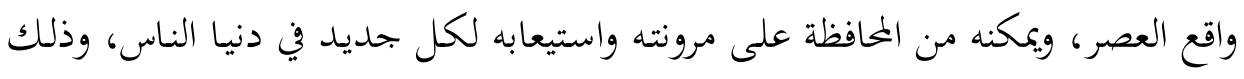

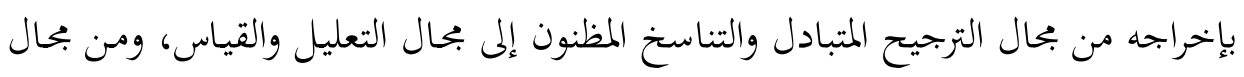
التعليل والقياس إلى بحال موازنات المصالح العامة واتخاذ القرارات الاستراتيجية." 10

ب. للظرف الاجتماعي الذي ورد فيه النص مدنحل لا يستهان به في إدراك المقاصد

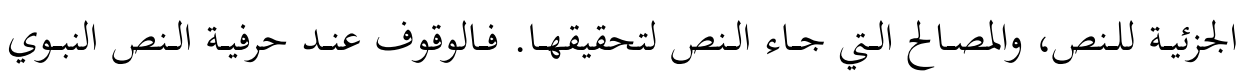

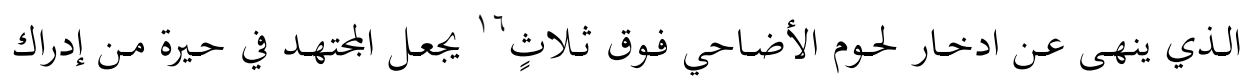

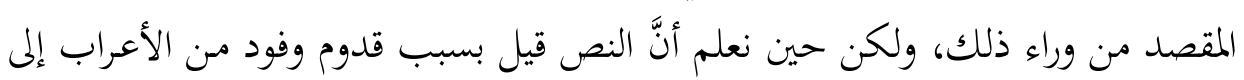

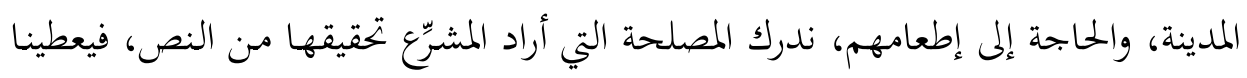
ذلك معرفة متى نُعمل النص مرة أخرى.

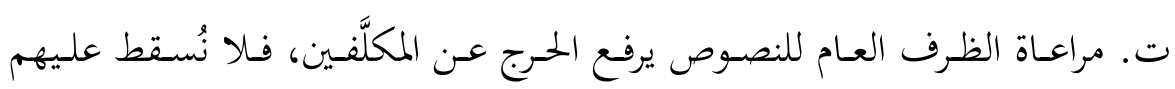

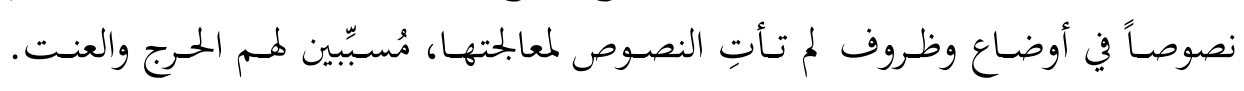

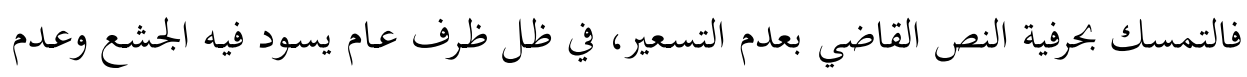

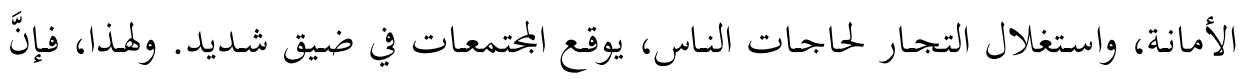
بتر النص عن واقعه يُفضي إلى مآلات لا تتفق ومقاصد الشريعة وغاياتها.

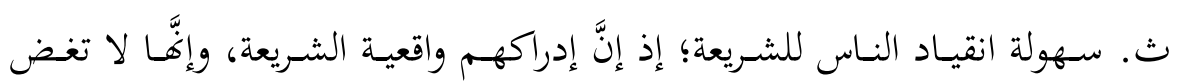

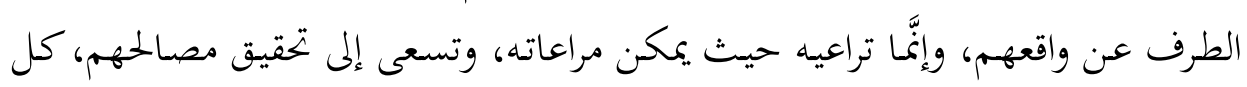
ذلك يُسهِّل انقيادهم لما.

- مسلم، المسند الصحيح المختصر، مرجع سابق، كتاب: الجنائز، باب: استئذان الببي ربه في زيارة قبر أمه،

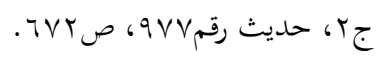
10 عودة، جاسر . فقه المقاصد: إنطاطة الأحكام الشرعية بمقاصدها، فرجينيا: المعهد العالمي للفكر الإسلامي،

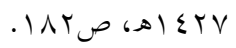

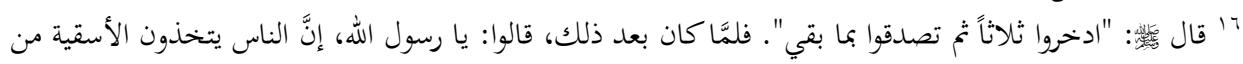

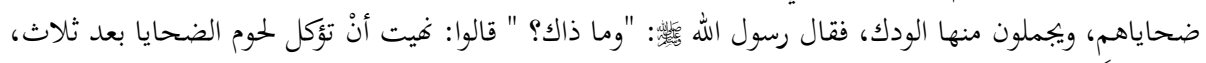

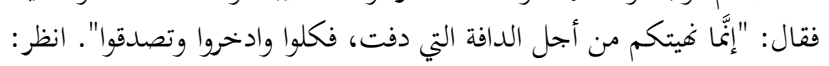

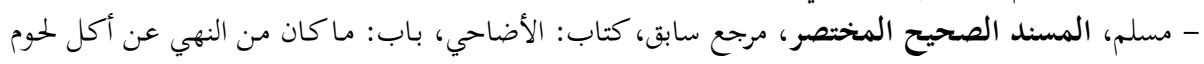

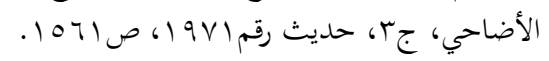




\section{ع ـ ماهية التأويل وموجباته:}

التأويل لغةً: المرجع والمصير، وهو مشتق من آل يؤول إلى كذا؛ أي صار إليه، وأولته صيرته إليه.

أمَّا التأويل اصطلاحاً فهو احتمال يعضده دليل يصير به أغلب على الظن من المعنى

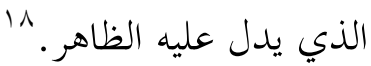

والتأويـل خـلاف الأصـل؛ فالأصـل حمـل النصـوص على ظاهرهـا. وهـذا، لا يجــوز اللجوء إليه من دون موجب. وفيما يأتي أبرز موجباته:

أ. التعـارض الظـاهري بـين النصـوص، مثل: تخصـيص العـام، وتقييـد المطلق، ونقـل

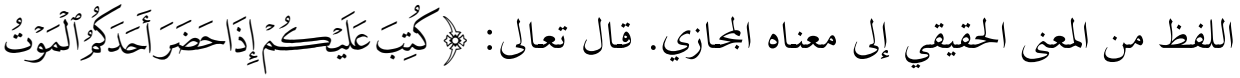

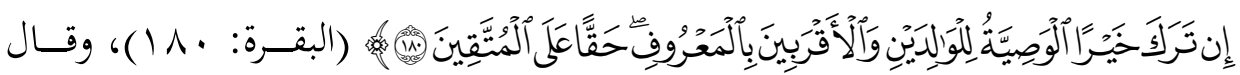
لَّ الوصية للوالدين والأقربين من الورثة وغيرهم، ومنع الوصية للوارث، وهو ما أزال التعارض الظاهري بجعل النص النبوي مخصصاً للنص القرآني، وتخصيص العام في عرف الأصوليين

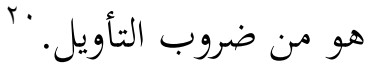

ب. تعارض النص الجزئي مع الأصل العام؛ إذ يجب تأويل النص الجزئي بحيث يتسق

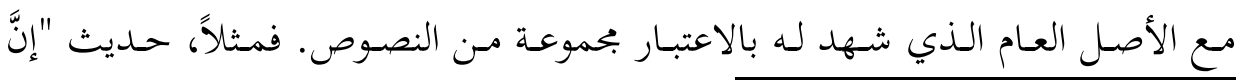

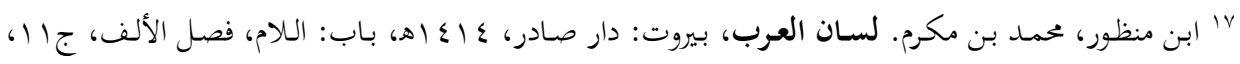

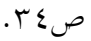

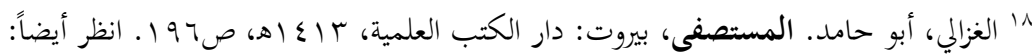

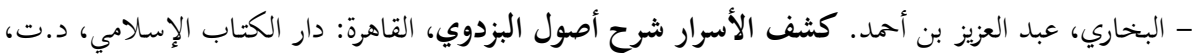

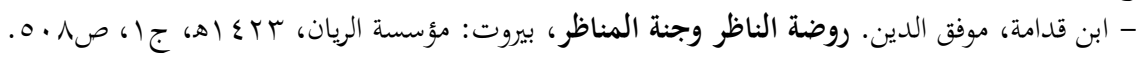

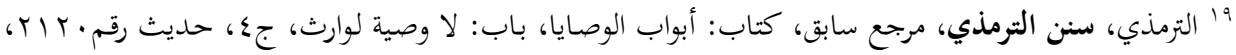

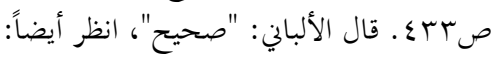

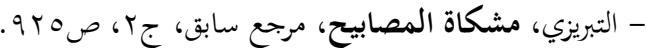

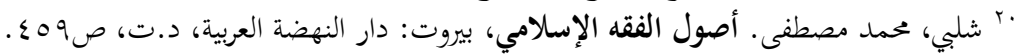


الميت يعذَّب ببعض بكاء أهله عليه"'r يتعارض مع الأصل الذي ينفي مسؤولية الإنسان

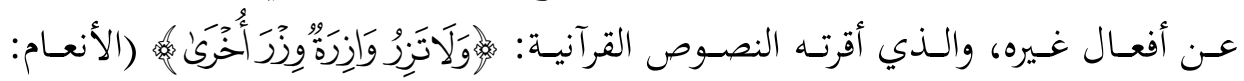

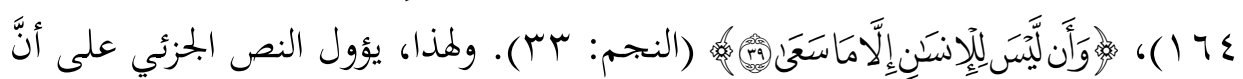

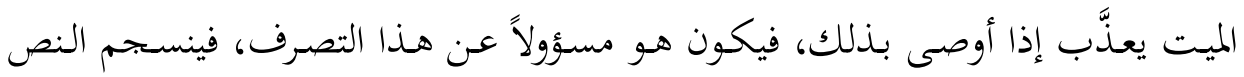

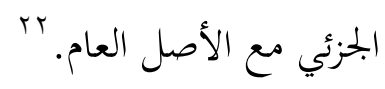

ت. عدم اتفاق مآل تطبيق النص الجزئي مع الحكمة من تشريعه. يقول الشاطبي:

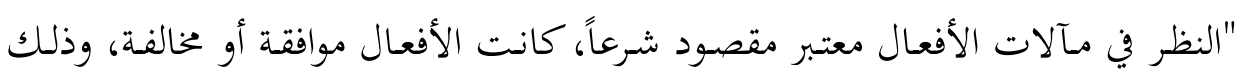

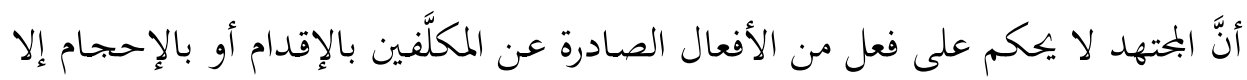

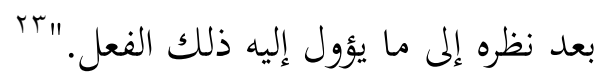

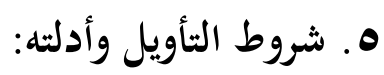
لا يُعَدُّ التأويل صحيحاً إلا بتوافر بحموعة من الشروط، هي: عَ أ. أنْ يكون اللفظ محتملاً للمعنى الذي يؤول إليه، وأنْ يكون احتمال اللفظ على

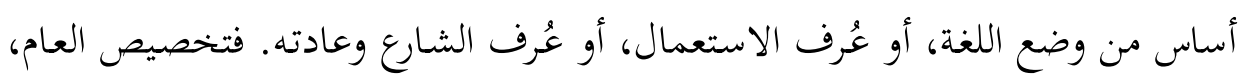
وتقييد المطلق، وإرادة المعنى المحازي؛ كل ذلك يتسق مع عُرف الشارع وعادته، حتى شاع

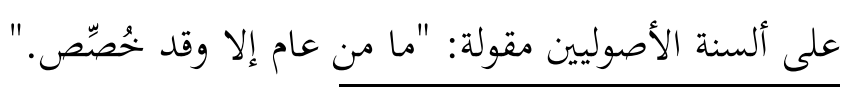

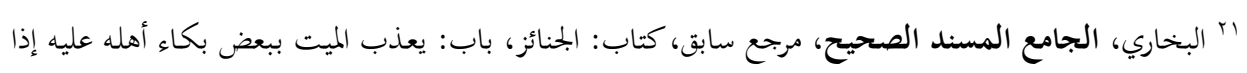

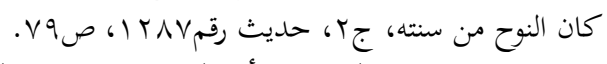

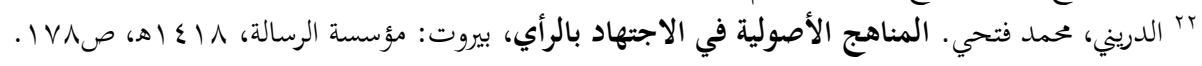

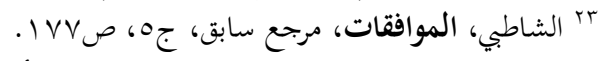

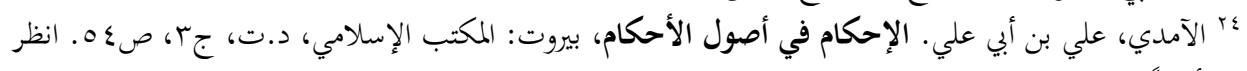
أيضاً:

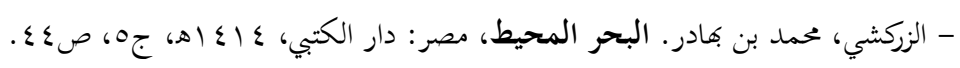

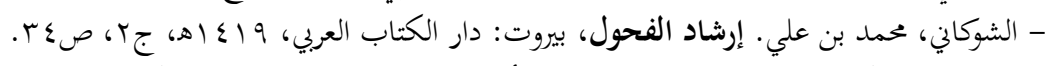

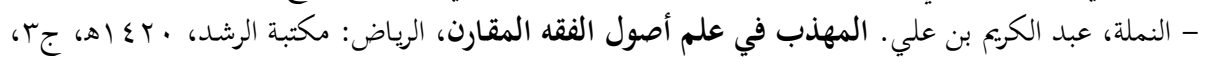
صV.r. - السلمي، عياض بن نامي. أصسول الفقـه الذذي لا يسـع الفقيـه جهله، الرياض: دار التدمرية، بrع اهـ، 
ب. أنْ يقوم التأويل على دليل صحيح يدل على صرف اللفظ عن ظاهره إلى غيره. ت. أنْ يكون المؤول من أصحاب الملكات الاجتهادية. ث. أنْ لا يعارض التأويل نصوصاً صريحةً قطعيةً الدلالة في التشريع. ولمَّا كانت النصوص الشرعية مُعبِّة عن معانيها بذاتما فإنَّ "الأصل حمله -اللفظ-

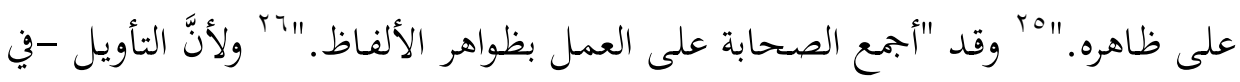

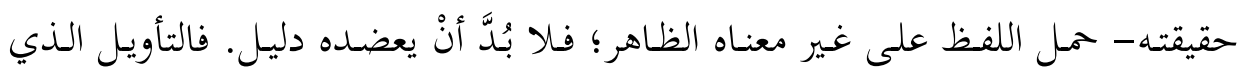
يفتقر إلى الدليل تأويل فاسد، وهو تصرُّف في المعاني من دون دليل، وفيه استبعاد لإرادة

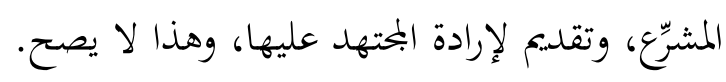

وباستقراء أقوال الأصوليين، فقد يكون دليل التأويل: نصاً شرعياً، أو قرينةً متصلةً أو

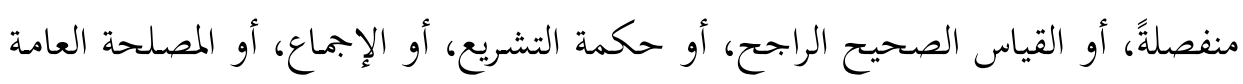
rV الحقيقية.

وقد عبَّر الأصوليون عن الظروف المحتفة بالخطاب الشرعي بمسميات كثيرة، منها: القرينـة الحاليـة، وحكمـة التشـريع، والمقاصــ العامـة الحقيقيـة، مــا يــل على اعتبـارهم الظروف المحتفة بالخطاب الشرعي من أدلة التأويل. ولهذا، بند بعض المباحث الأصولية تُخصِّص العام بالعِلّة، والعادة، والعُرف المقارن، والمصلحة، إلى غير ذلك من المباحث التي تندرج في سياق الظروف المحتفة بالخطاب الشرعي.

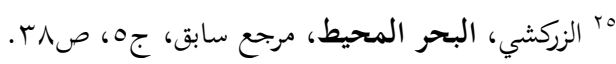

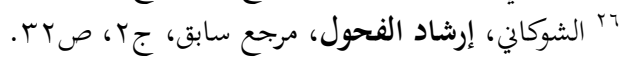

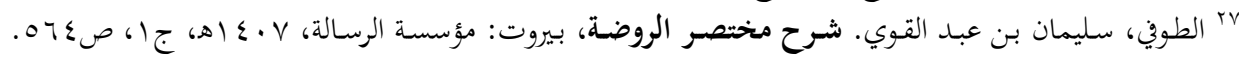
انظر:

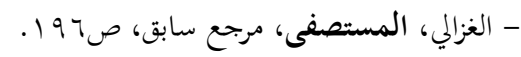

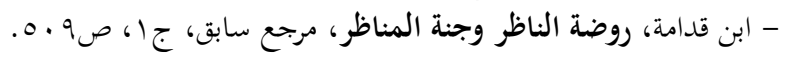

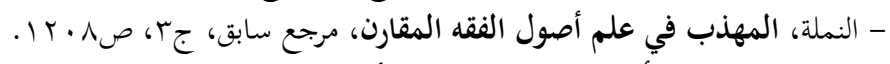

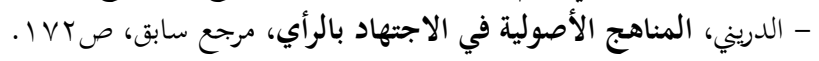




\section{ثانياً: أثر الظروف المحتفة بالخطاب في تأويل النص الشرعي}

ناقشنا بإيجاز الظروف المتفة بالخطاب؛ ماهيتها، وكيفية الوقوف عليها، وأهميتها، ثم

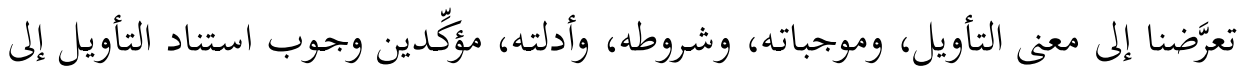

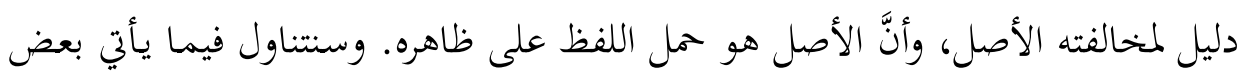

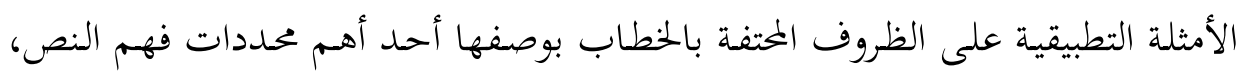

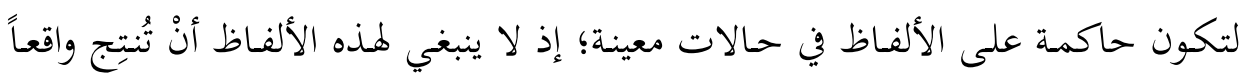
يتعارض مع الواقع الذي شُرعِ النص من أجله.

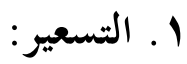

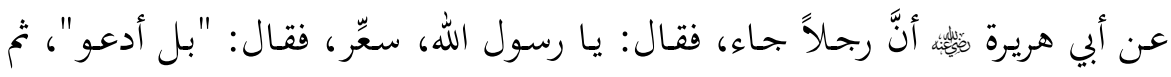

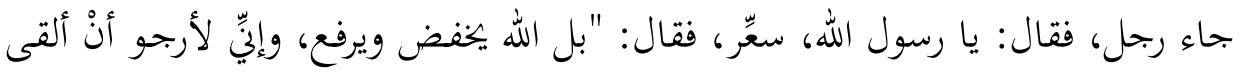

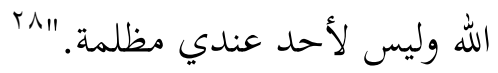

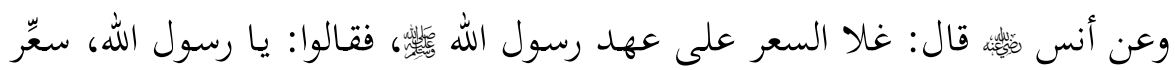

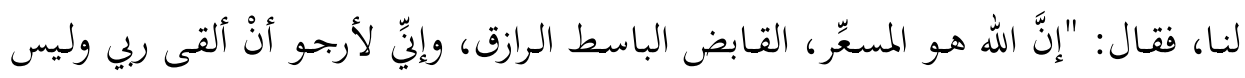
أحد منكم يطلبني بمظلمة في دم ولا مال."

فهذان النصان يدلان بعباراتها على عدم مشروعية التسعير، وأنَّه لا يحق للدولة أنْ

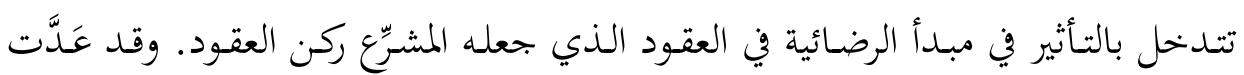

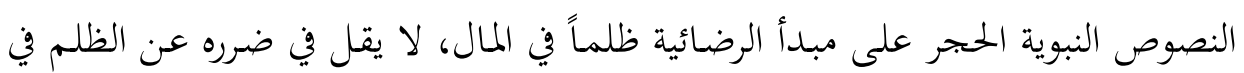

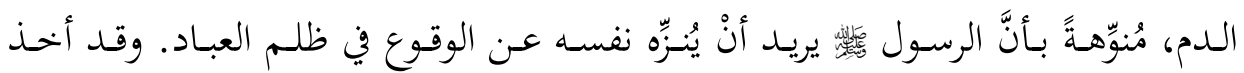

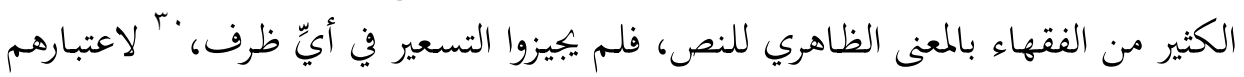

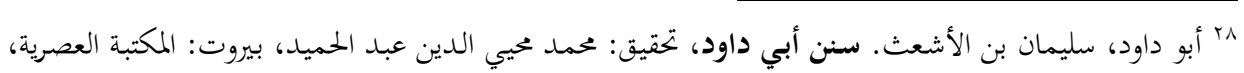

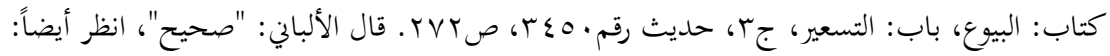

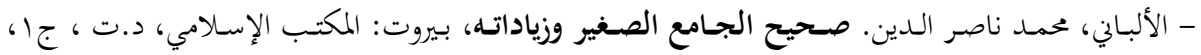

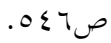

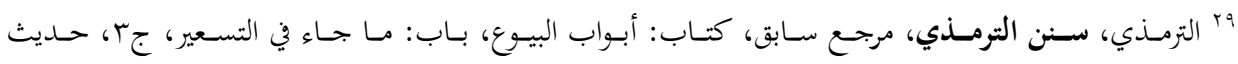

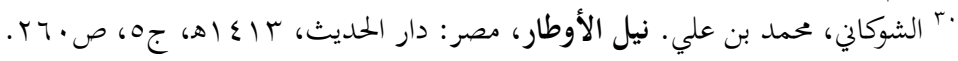


أنَّ ما تضمَّنه الحلديث من معنى غير مرتبط بزمان أو مكان، ووإنَّا هو حكلم مطلق لجميع البيئات في مختلف الظووف.

وهــا الفهـم الظـاهري للـنص خـالفـه بعض الفقهـاء، فتـالوا بجـواز التسعير، أمثـال:

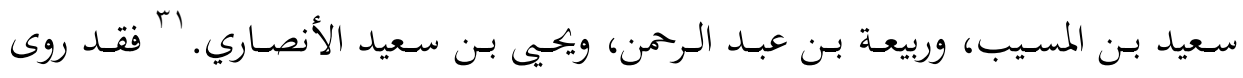
أشهب عن مالك القول بجوازه، قال مالك: "إذا سعِّر عليهم قدر ما يرى من شرائهم فلا

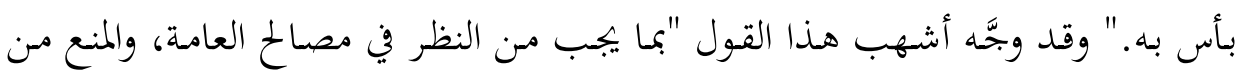

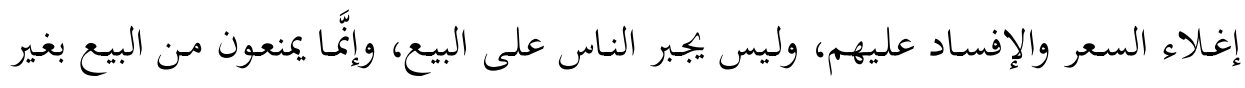
السعر الذي يهدده الإمام، على حسب ما يرى من المصلحة فيه للبائع والمبتاع، ولا يمنع

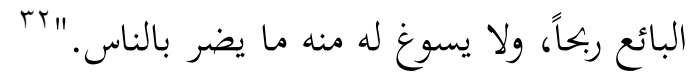

ويقول ابن تيمية في بيان فهمه لهذه النصوص: "... ومن هنا يتبـنَّن أنَّ السعر منه ما

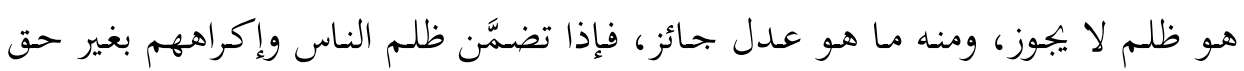
على البيع بثمن لا يرضونه، أو منعهم محا أباحه الله لهم فهو حرام، وإذا تضمَّن العدل بين

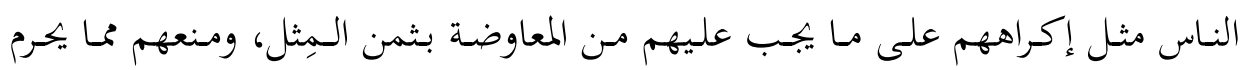
عليهم من أخذ زيادة على عوض المِثل، فهو جائز بل واجب.." وأمَّا حُجــة ابن تيميـة لهذا التأويل المخـالف لظـاهر النص فهري الظروف المتفـة بـه. يقول ابن تيمية مبرِّرً رأيه: "فإذا كان الناس يبيعون سلعهم على الوجحه المعروف، من غير

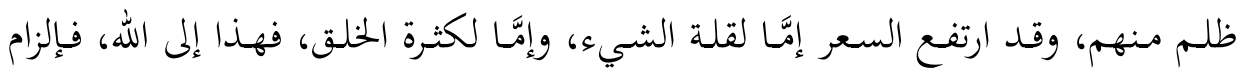
الخلق أن يبيعوا بقيمـة بعينها إكراه بغير حق، وأمَّا أنْ يمتنع أربـاب السـلع مـن بيعها مـع ضرورة الناس إليها إلا بزيادة على القيمة المعروفة، فهنا يجب عليهم بيعها بقيمة المثل، ولا معنى للتسعير إلا إلزامهم بقيمة المثل. "ـ" ويقول ابن القيم: "فالتسعير هاهنـا إلزام بالعدل الذي ألزمهم الله به. " الذهبر

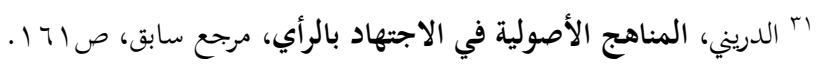

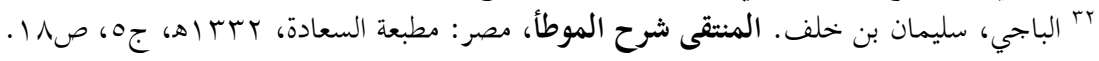

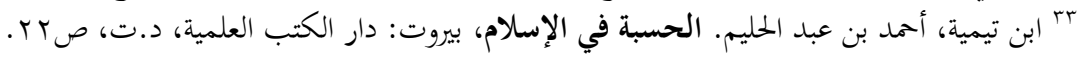

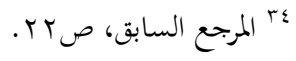

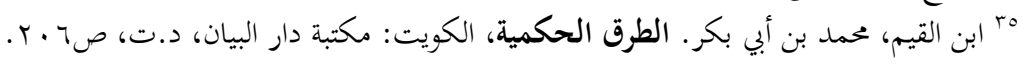


وأمَّا إذا احتكر أناس معينون الابِّحار بسلعة ما فقد أوجب ابن القيم على الدولة -

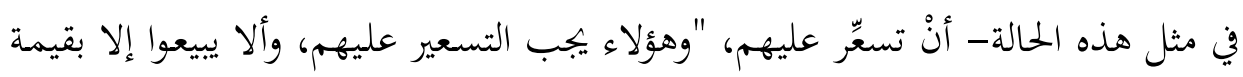

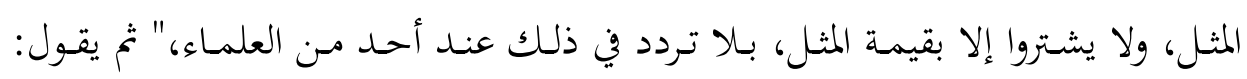

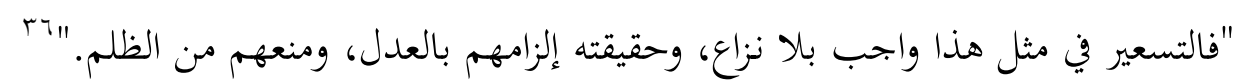
إنَّ هذا التأويل للنص النبوي يستند إلى أصول قطعية في الشريعة؛ من: رفع الظلم،

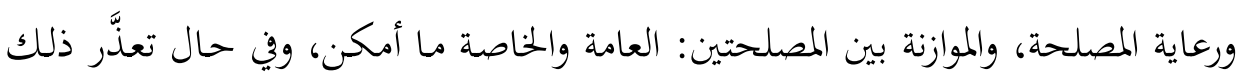
فإنَّ المصلحة العامة تُرجَّح على المصلحة الخاصة. وقد كان هذا هو الباعث على امتناع النبي

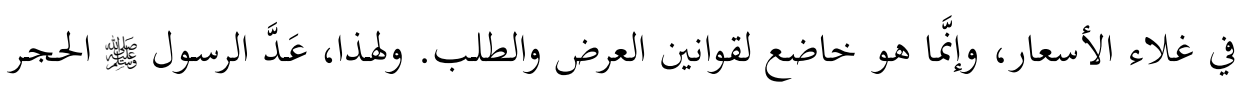

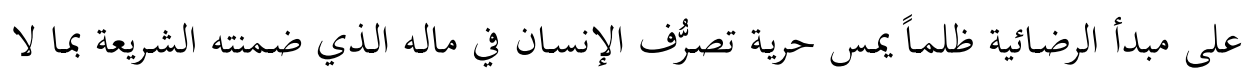
يلحق الضرر بالآخرين، وصولاً إلى المقصد العام وهو حفظ أموال الناس. ولكن، إذا تغيَّر

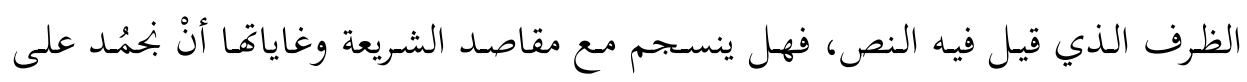
ظاهر النص الذي يُفضي إلى ظلم العامة؟ من هنا، فقد كان لزاماً تأويل النص، ترسيخاً

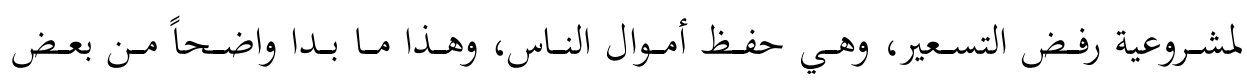

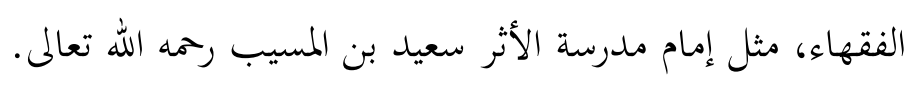
والواقع أنَّ الجمـود على ظاهر النص ورفض تأويله سيؤدي -في حسال تطبيقه- إلى

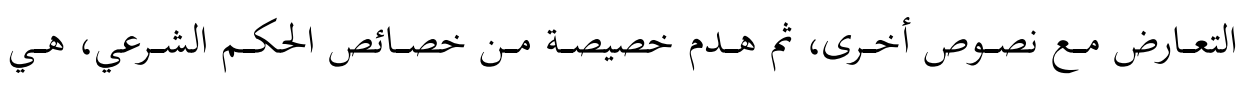
الانسـجام والتناسـق وعـدم التعـارض. فلـو أبحنـا للبـائع أنْ يبيـع كيـف يشـاء في جميـع

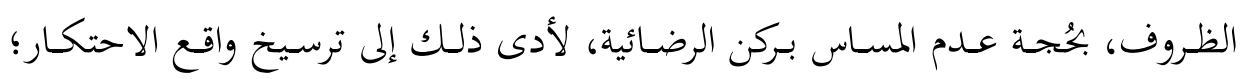

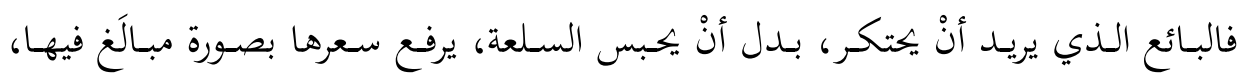
ويصل إلى المعنى الذي يحقِقه الاحتكار. 


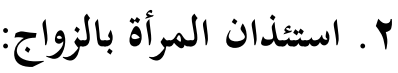

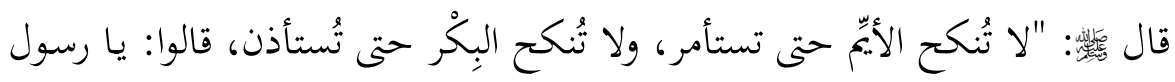

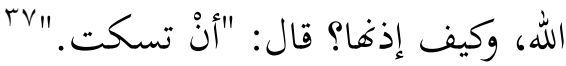

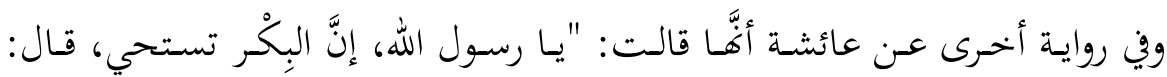

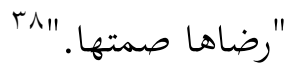

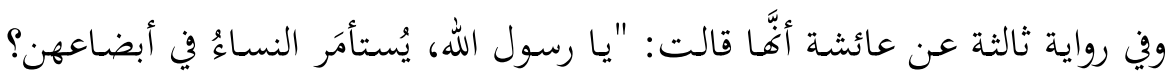

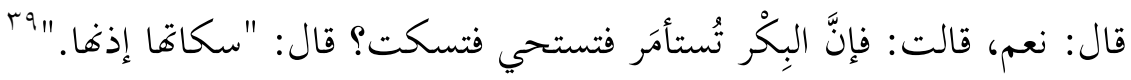

فقد حرص الإسلام على بناء العقود على مبدأ الرضائية، وأيُّ عقد قصر عن تحقيق

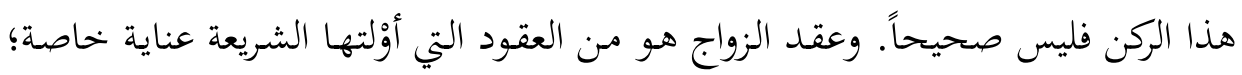

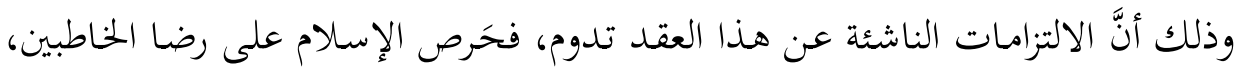
وذلك أدعى إلى تحقيق مقصوده من دوام العشرة الزوجية.

والأصل في العقود أنَّ العاقد لا بُدَّ أنْ يصدر منه ما يدل على وجود الرضا، وينفي

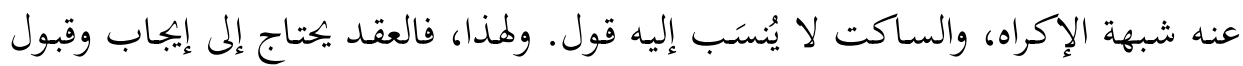

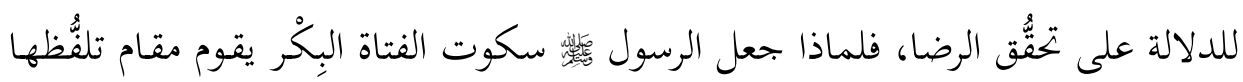

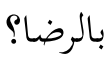

إنَّ النصوص النبويـة الآنف ذكرهـا تضمَّنت في ثناياهـا الظروف الاجتماعيـة التي

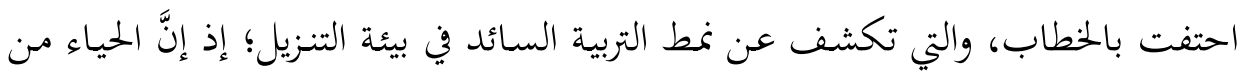

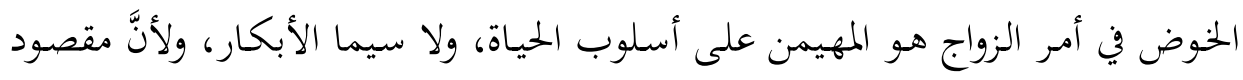

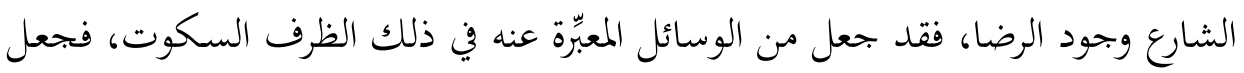

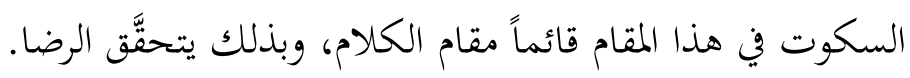

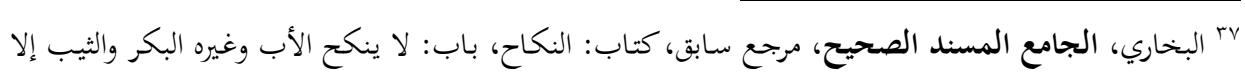

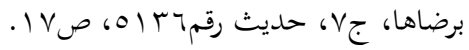

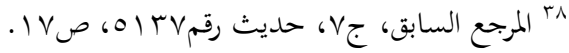

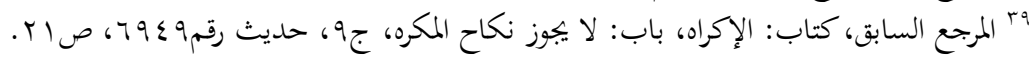


والوقوف عنــ حرفيـة النص وظـاهره يوجـب أنْ يكـون هـذا الأسـلوب (السـكوت)

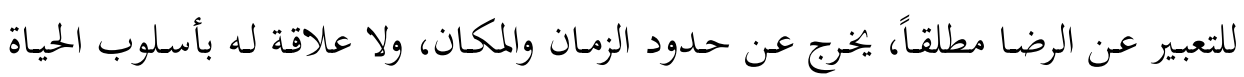
السائد، ولا بالعادات الاجتماعية، فلو ساد نمط إكراه الفتيات على الزواج، وسكتن من لن

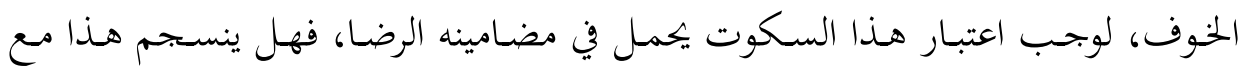
مقاصد الشريعة؟ - مبع إذن، يجبـب أنْ تكون قراءة النص الاستنباطية في سياق الظرفية التي قيل فيها، وإنَّ القفز عن ذلك يوحي أنَّ الإسلام لا يقيم اعتباراً لركن الرضا.

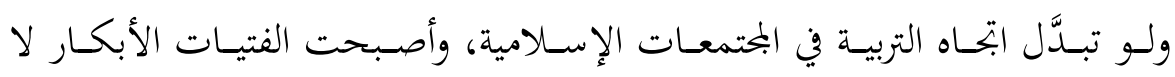

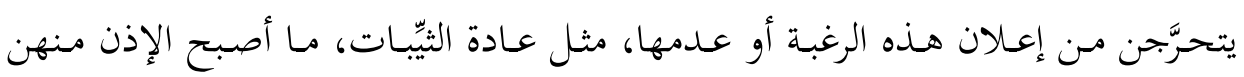
يكفي فيه السكوت. • وهذا الفهم الذي ذهب إليه العلَّامة الزرقا -رحمه الله- يتفق مع مقاصد الشارع من

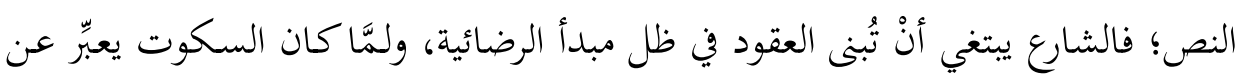

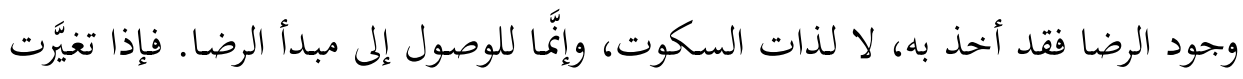
الظروف التي قيـل فيها النص، وأصبح السكوت قاصـراً عـن التـليل على وجـود مبـدأ

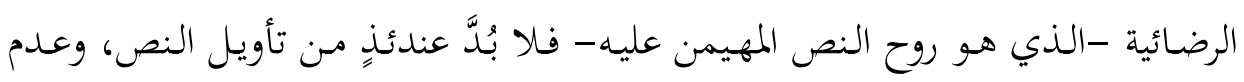

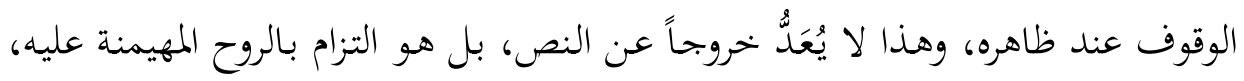

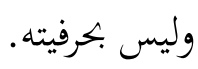

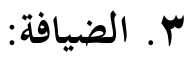

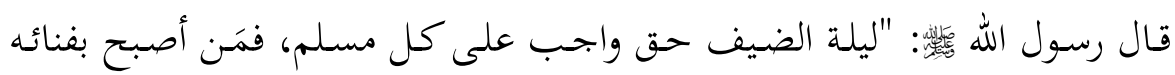

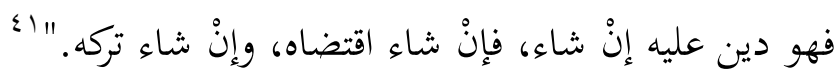

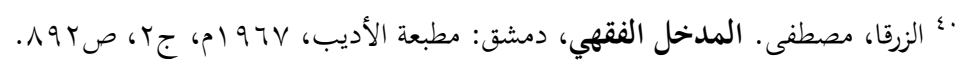

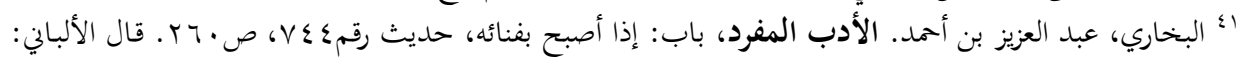

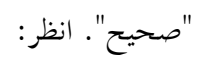
- الألباني، محمد ناصر الدين. صحيح الأدب المفرد، الجبيل: دار الصديق،ه إ اهـ، صVV. 


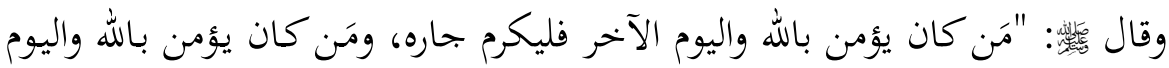

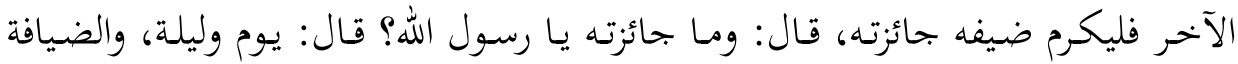

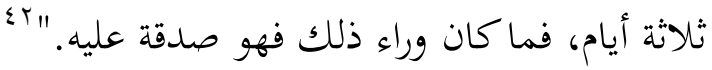

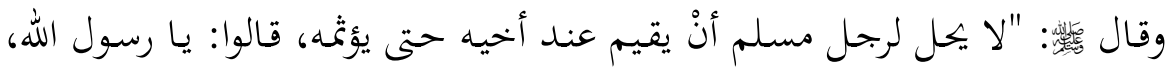
وكيف يؤثمه؟ قال: يقيم عنده ولا شيء له يقريه."

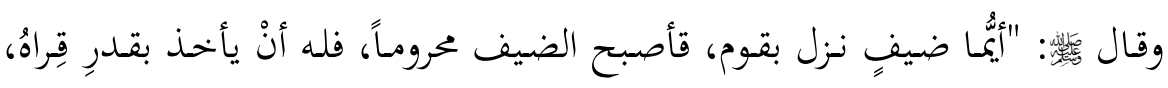

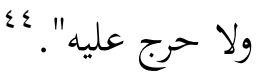

ويرى بعض الفقهاء أنَّ حكم الضيافة واجب،، مستدلين على مـا ذهبوا إليه بظاهر النصوص السـابقة، ومسن هـؤلاء: الإمـام أحمــــ في روايـة، وابـن حزم، والشـوكاني، وغـيرهم

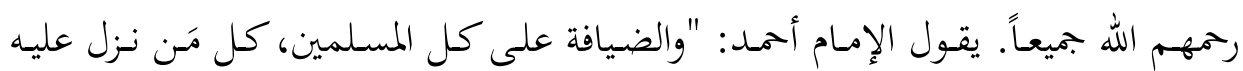

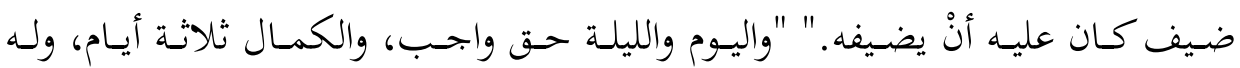

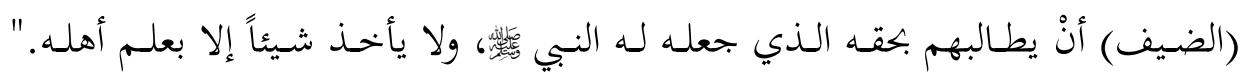

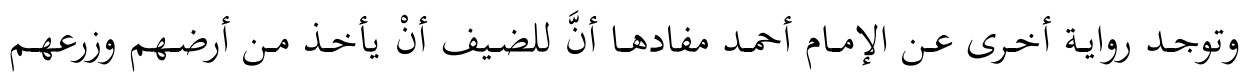
وضرعهم قدر ما يكفيه بغير إذهم.

ويقول ابن حزم: "الضيافة فرض على البدوي والحضري والفقيه والجحاهل، يوم وليلة،

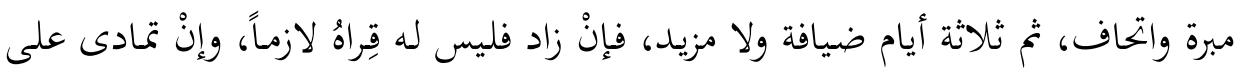
rأ البخاري، الجامع المسند الصحيح، مرجع سابق، كتاب: الأدب، باب: من كان يؤمن بالله واليوم الآخر فلا يؤذٍ

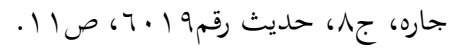

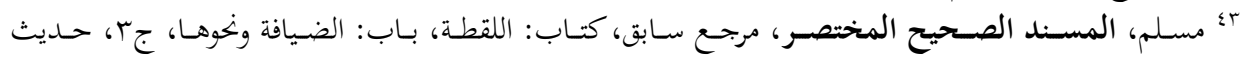

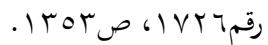

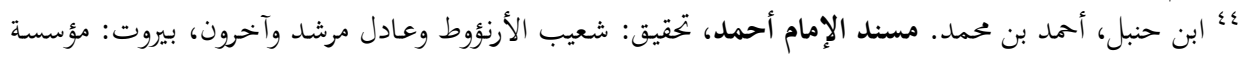

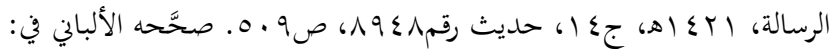

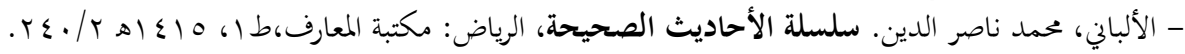

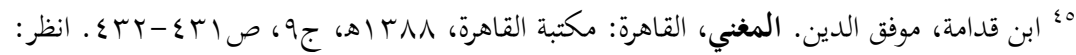

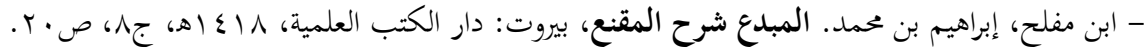

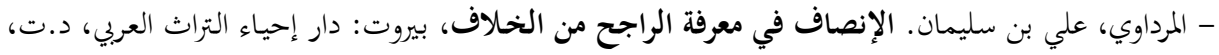

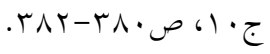


قِراهُ فحسـن، فبإنْ منـع الضسيافة الواجبـة فله أخـذها مغالبـةً، وكيف أمكنـه، ويقضى له بذلك." وقد عَدَّ ابن حزم قصر الفرض على على أهل البوادي رأياً في غاية الفساد. بـ يقول الشوكاني: والحق وجوب الضيافة لأمور، منها: v؛ أ. إباحة العقوبة بأخذ المال لمِن ترك ذلك، وهذا لا يكون في غير الواجب. ب. التأكيد البالغ بجعل ذلك فرع الإيمان بالله واليوم الآخر، ويفيد أنَّ فعل خحلافه فعلُ مَن لا يؤمن بالله واليوم الآخر، ومعلوم أنَّ فروع الإيمان مأمور بها.

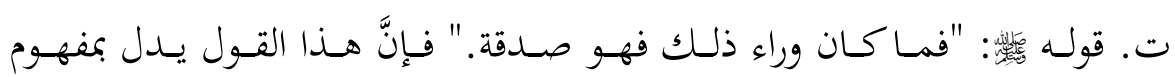
المخالفة أنَّ ما قبل ذلك ليس بصدقة، وإنَّا هو واجب فرو فرعاً. ث. قوله لَ على تأويل النص بصرفه عن الوجوب.

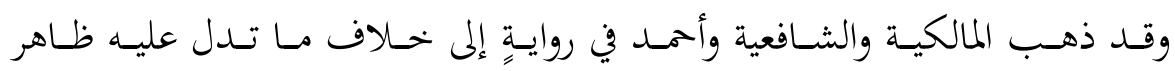
النصوص بعدم وجوب الضيافة على إطلاقها، بل بجدهم خصَّصوا هذه الأحاديث بواقع

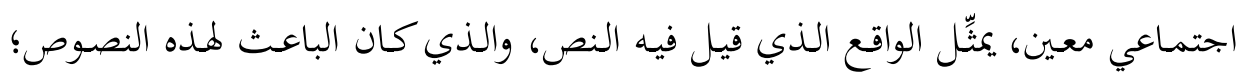

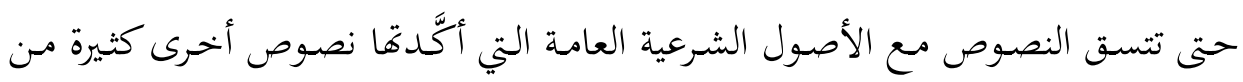
حرمة أموال المسلمين إلا عن طيب نفس. يقـول مالك: "الضـيافة إنَّـا تتأكَّد على أهـل القـرى، ولا ضـيافة في الحضر، لوجـود

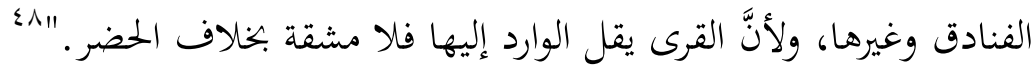
ويقول سحنون: "إنَّا الضيافة على أهل القرى، وأمَّا أهل الحضر فالفندق ينزل فيه المسافر. و" و

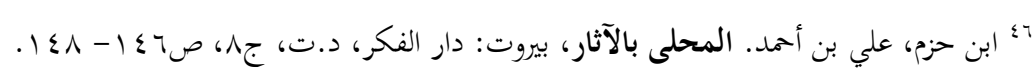

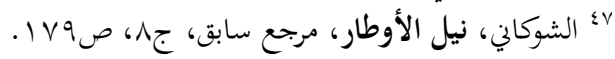

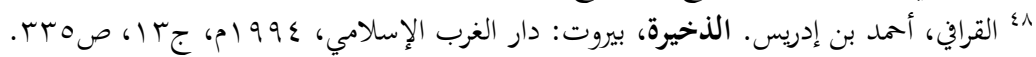

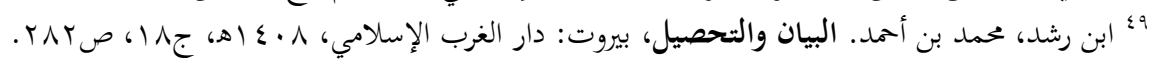


وأمَّا الشـافعي فقـد خصَّص النصـوص بالمضطر؛ إذ احتج على عـدم الوجسوب بـأنَّ الضيف غير مضطر إلى طعامه، فلم يجب عليه بذله. . يقول صاحب "كشاف القناع": "ولا بحـب الضيافة في الأمصار، لأنَّه يكون فيها

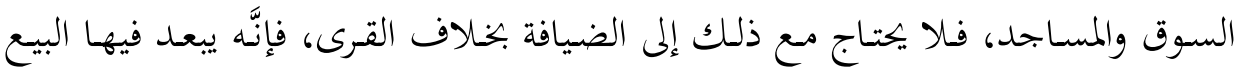

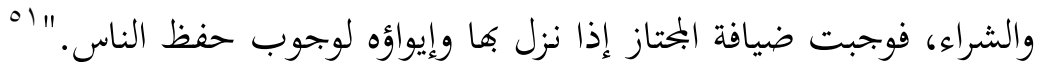
والحقيقـة أنبّ لسـتُ في معرض الترجيح بـين الأقوال المتعارضـة، فهـا ليس مقصسود

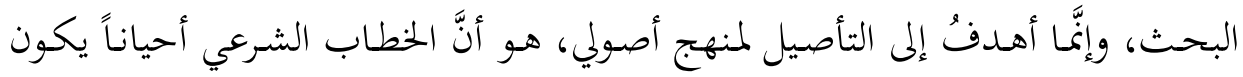

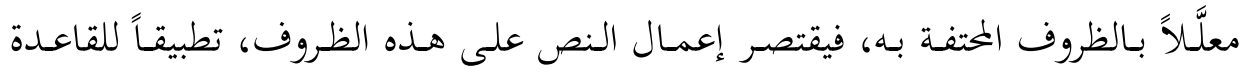
الأصولية: "الحكم يدور مع علّته وجوداً وعدماً." ولـمَّا كـان تخصسيص الإمـامين الجليلـين -التخصسيص ضـرب مـن ضـروب التأويل -

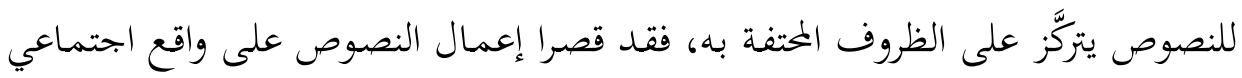

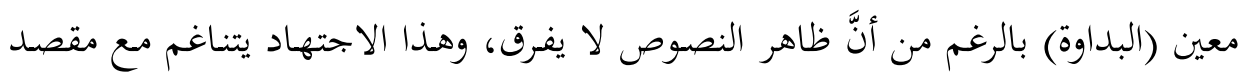

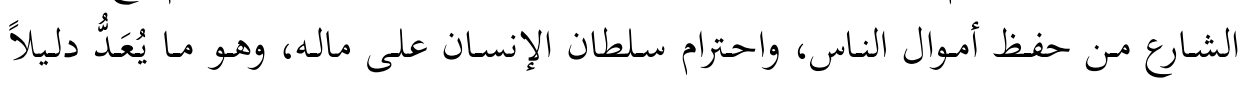
واضحاً على أنَّ الظرف المحتف بالنص -عند ورواده دليلاً من أدلة التأويل - كان حاضراً في اجتهادات الفقهاء، وإنْ لمُ يُصرِّحوا بذلك. بـانك.

\section{ع ـ علاج نشوز الزوجة:}

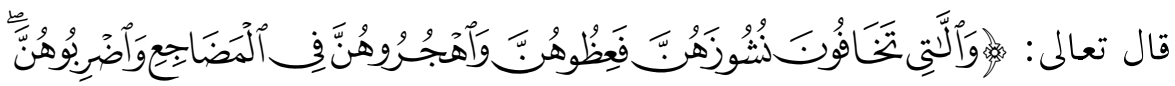

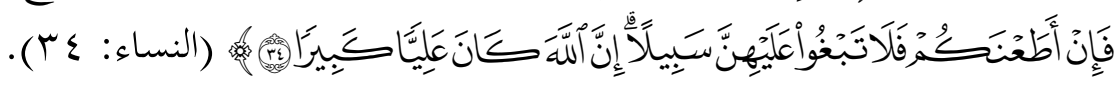

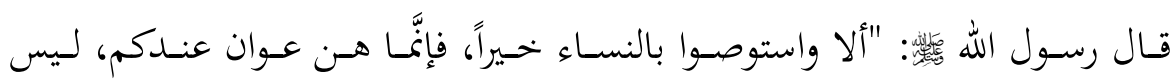

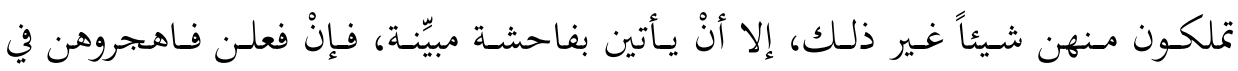

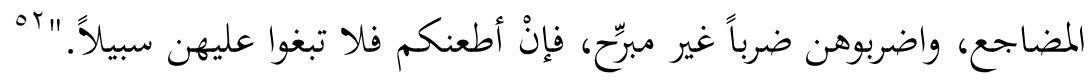

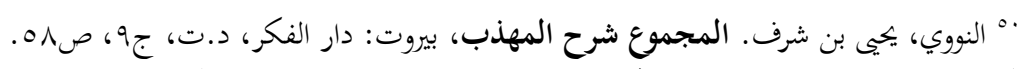

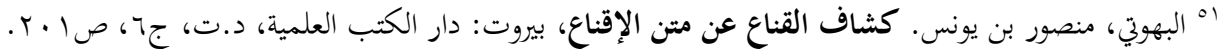

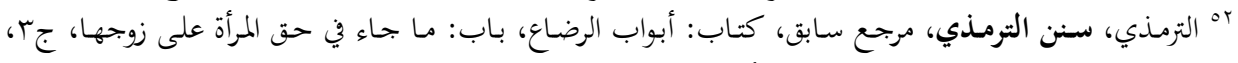

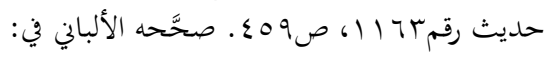


وعن حكيم بن معاوية القشيري عن أبيه، قال: قلت: يا رسول الله، مـا حق زوجة

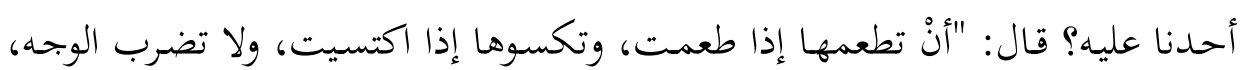

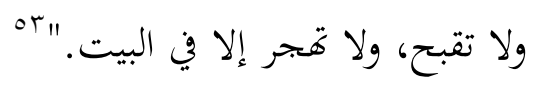

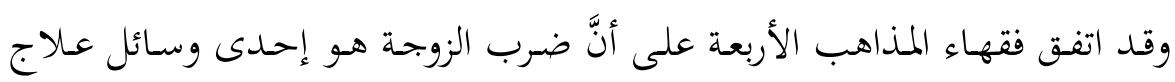

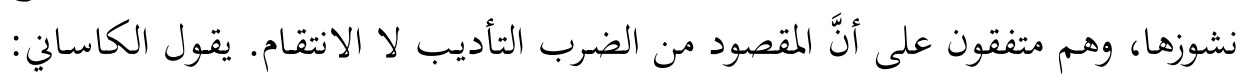

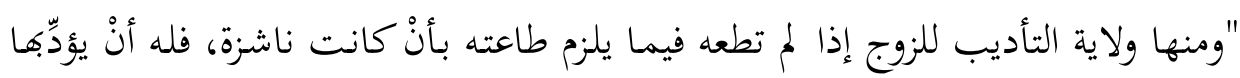

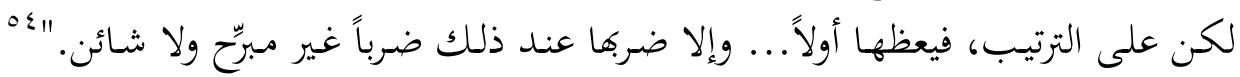

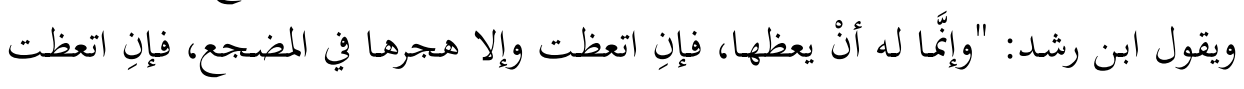

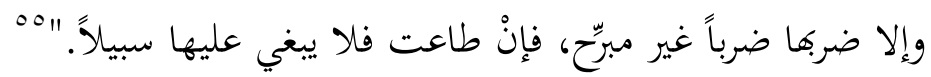

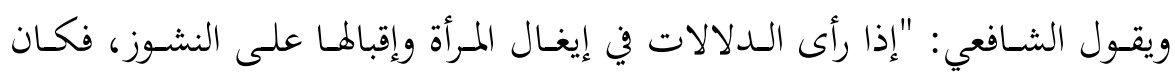

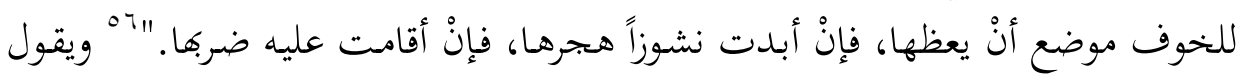

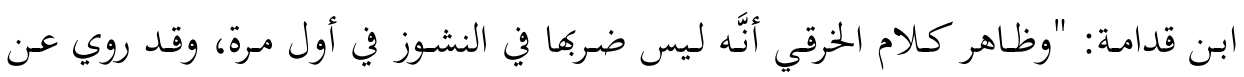

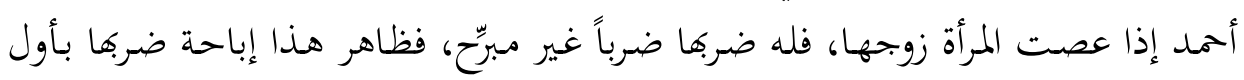
مرة.

وقد ضبط صاحب "الحاوي الكبير" الضرب بأنْ يكون "بالثوب، والنعل، وأكثره

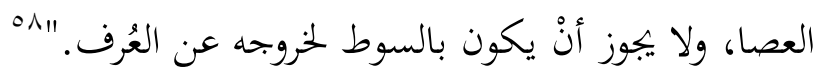

يقول القرطبي في تفسير الآية التي هي محل البحث: "أمر الله أنْ يبدأ النساء بالموعظة

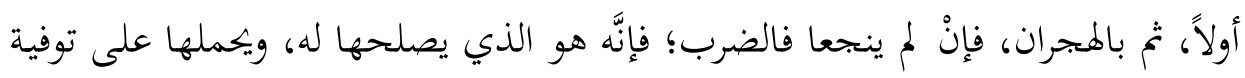

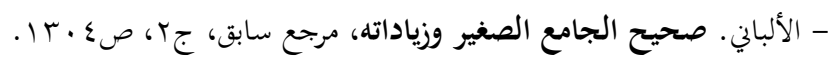

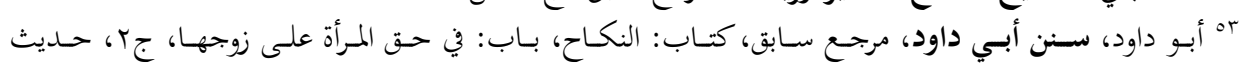

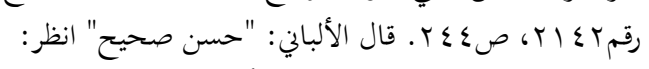

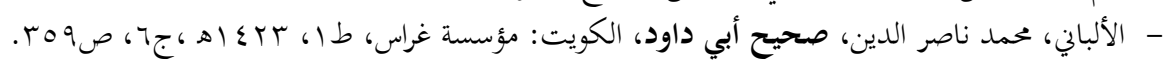

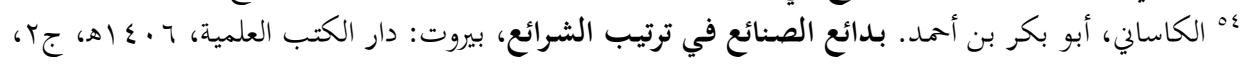
صع بr.

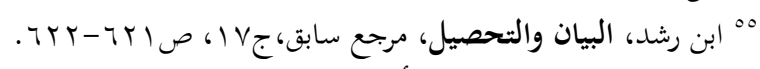

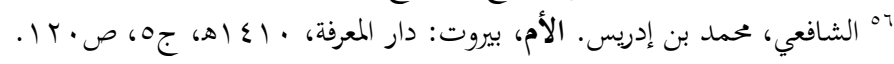

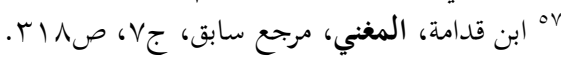

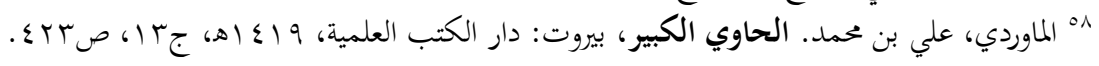


حقه. والضرب في هذه الآية هو ضرب الأدب غير المبرِّ، وهو الذي لا يكسر عظماً،

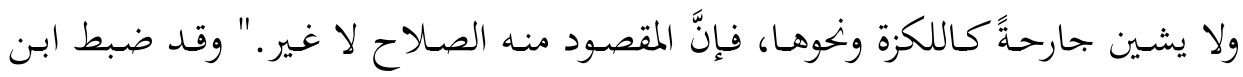
عباس الضرب بالسواك ونغوه.

ولا شـكَّ في أنَّ هـذه القضية هي من أكثر القضايا وعورةً في هذا العصر؛ وهو مـا دفع المتخصصسين في العلم الشـرعي إلى بـل جهود مضـنية في محاولة المقاربة بينها وبين روح العصر، الـذي أصبحت حقـوق الإنسـان أهـم العناصـر المكوِّنة لثقافته، ولا سـيما حقوق المرأة، فكيف السبيل إلى المواءمة بين كفالة الإسلام حق الإنسان، ولا سيما المرأة،

$$
\text { والسماح بضربها؟ }
$$

لقـــ تبـوَّأت هــذه القضـية مركـز الصـدارة في مهاجمـة الثقافـة الإسـلامية والتصـور

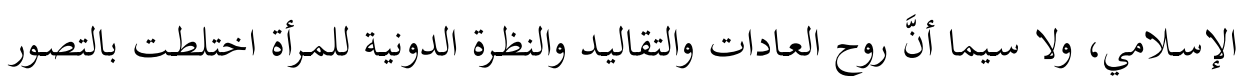
الشرعي، فأصبحت كلها في نظر الآخرين ثقافةً إسلاميةً.

وأمَّا إمـام المقاصد في هذا العصر الطاهر بن عاشور -رحمه الله- فقد قرأ هذه الآية بصورة مغايرة؛ إذ نظر إليها معلَّلةً بالظروف التي احتفت بها، يقول في ذلك: "قال جمهور

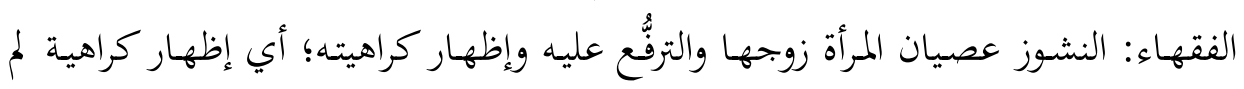
تكن معتادة منها؛ أي بعد أنْ عاشرته، كقوله:

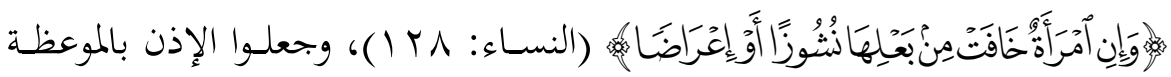

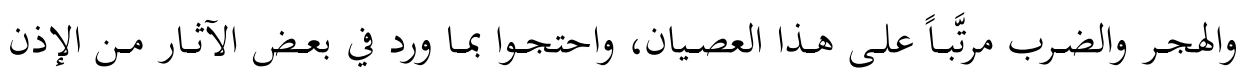

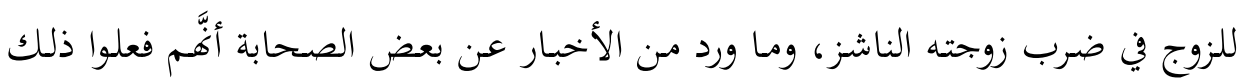

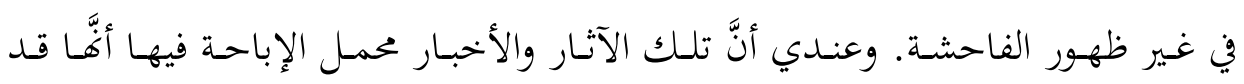

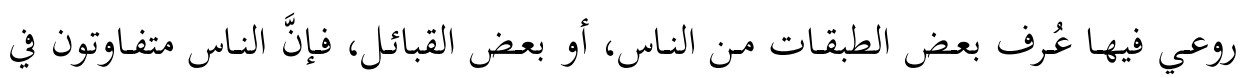

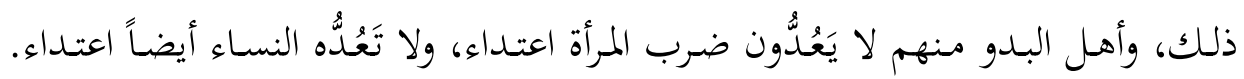

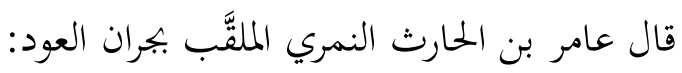

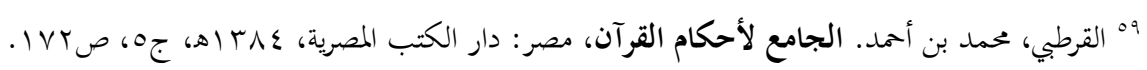




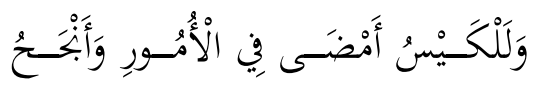

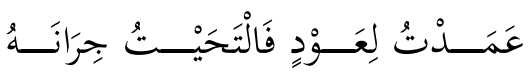

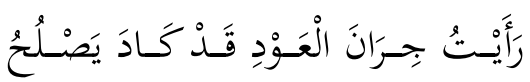

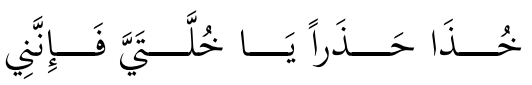

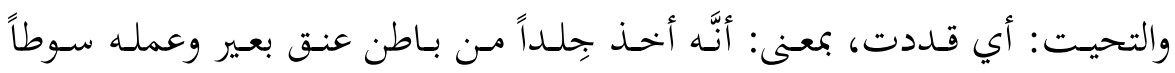

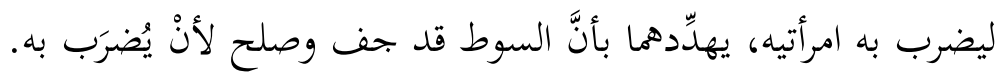

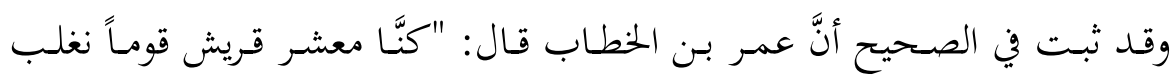

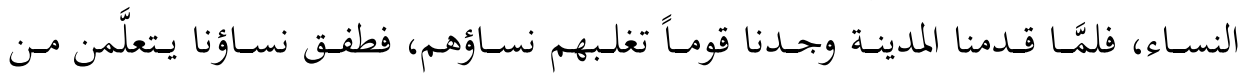

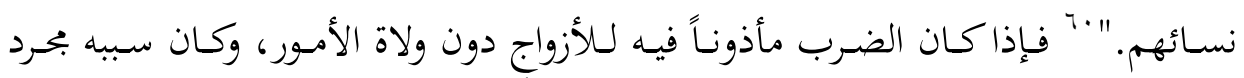

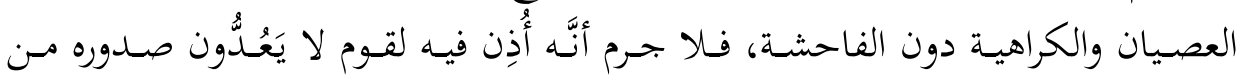

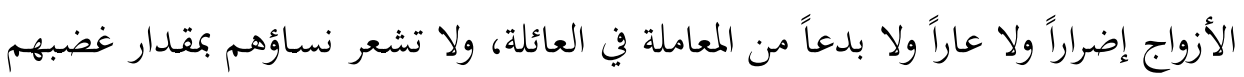

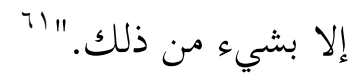

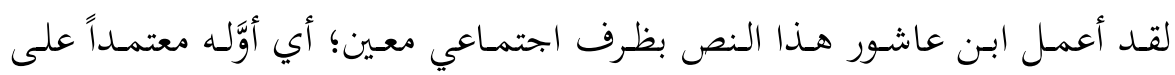

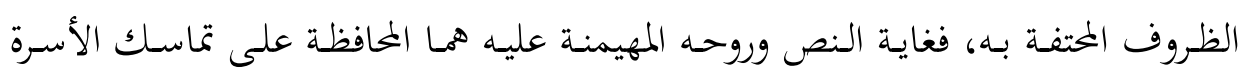

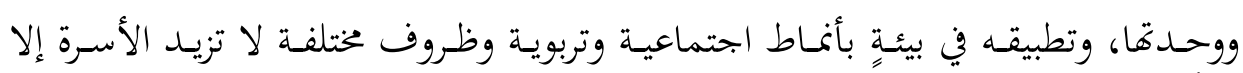

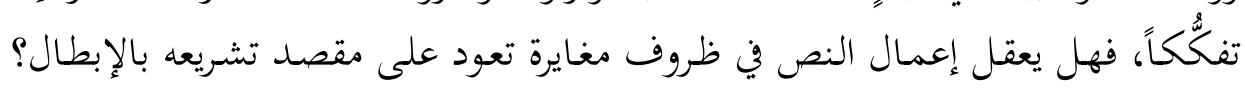

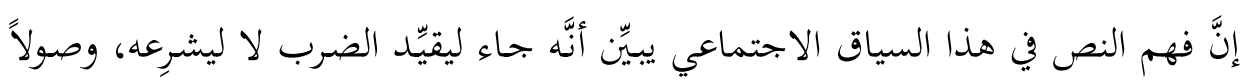

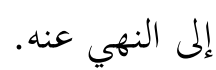

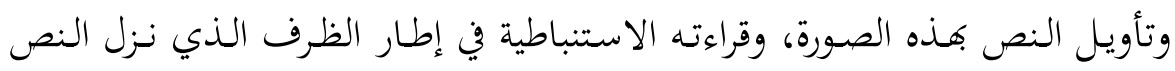

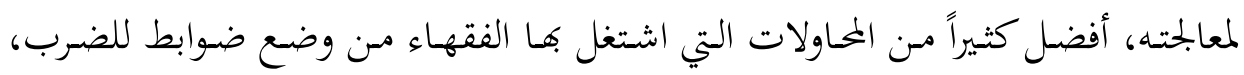

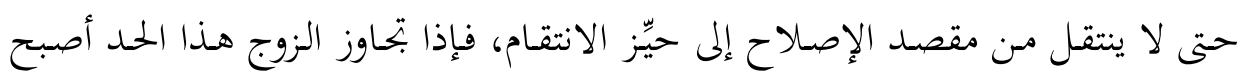

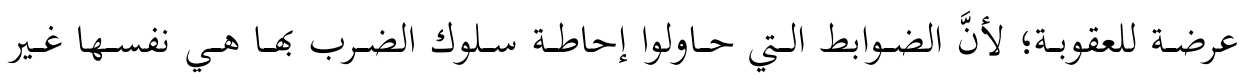

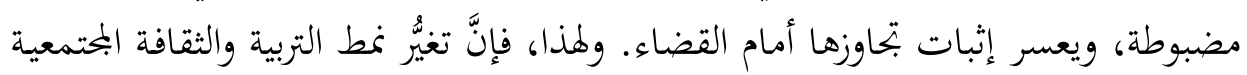

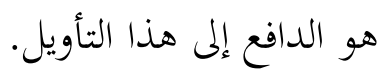

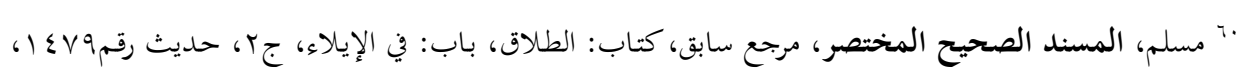




\section{ه. (السلام على أهل الكتاب، والتضييق عليهم في الطرق:}

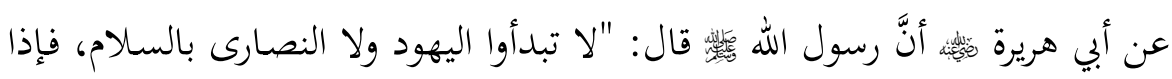
كقيتم أحدهم في طريق فاضطروه إلى أضيقه."

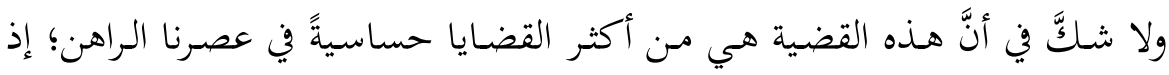

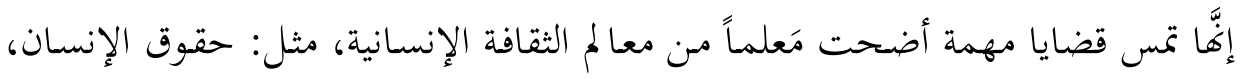

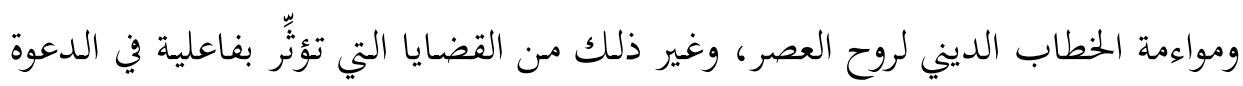

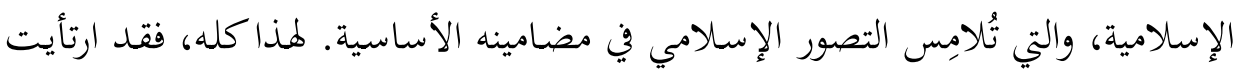

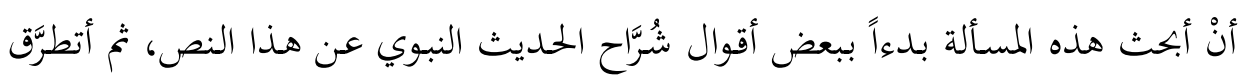

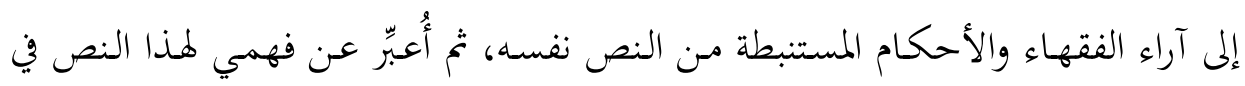
سياق الظرف الاجتماعي الذي ورد فيه.

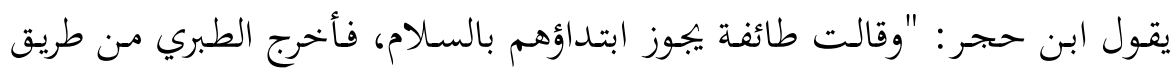

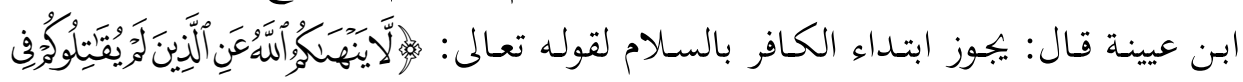

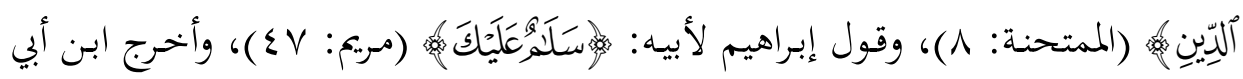

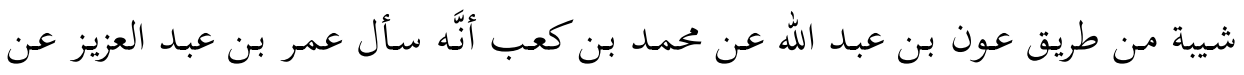

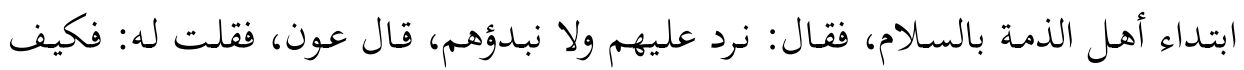

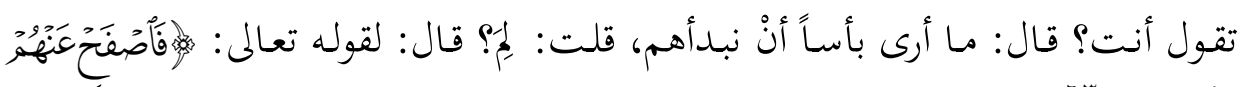

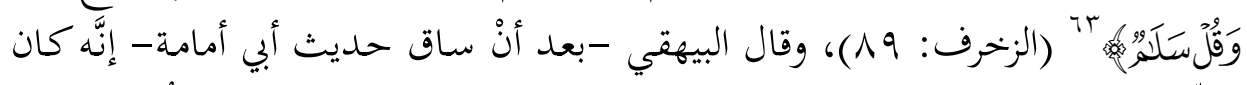

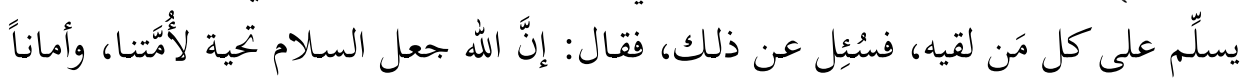

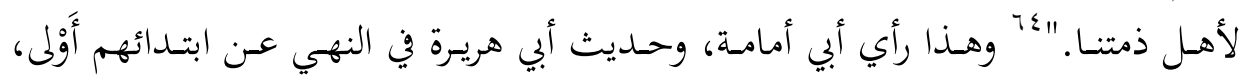

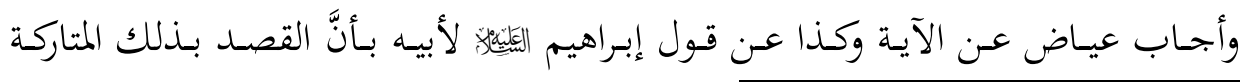

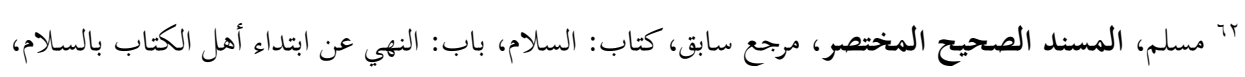

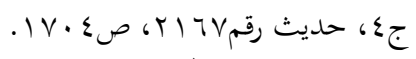

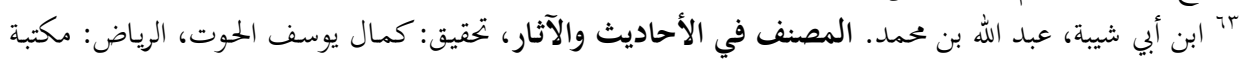

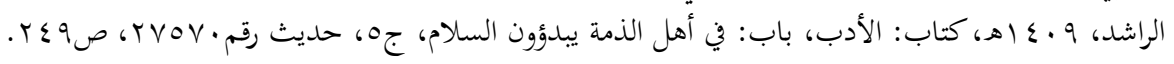

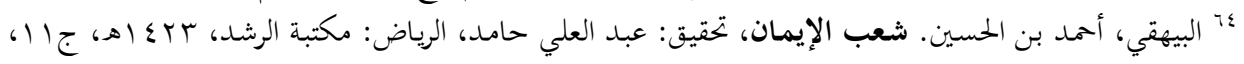

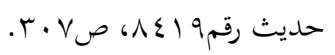




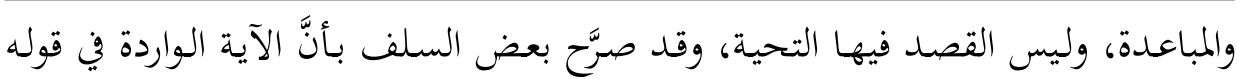

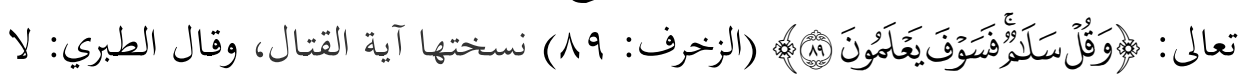

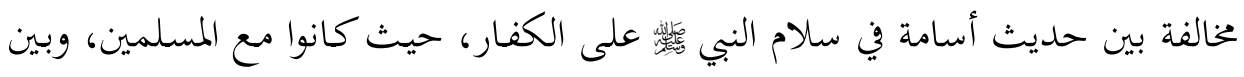

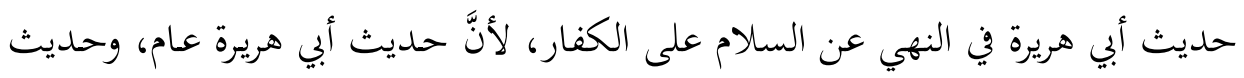

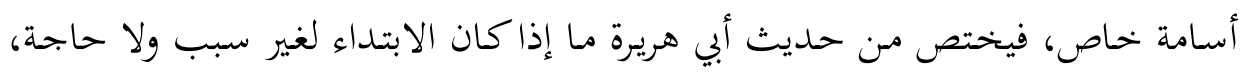

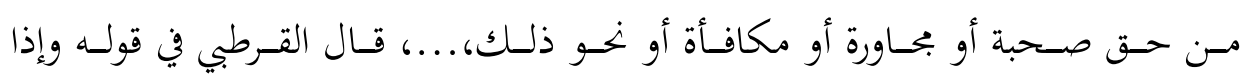

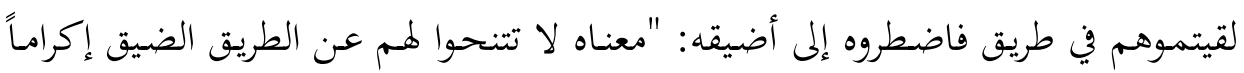

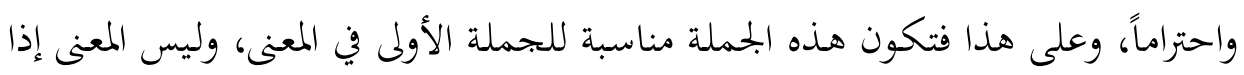

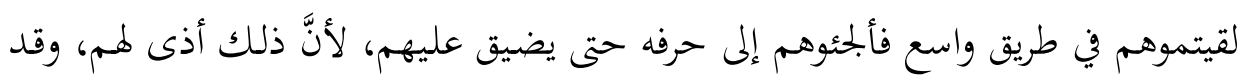
كُينا عن أذاهم بغير سبب.

ويقول النووي: "قال أصحابنا: لا يُترك للذمي صدر الطريق، بل يُضطر إلى أضيقه

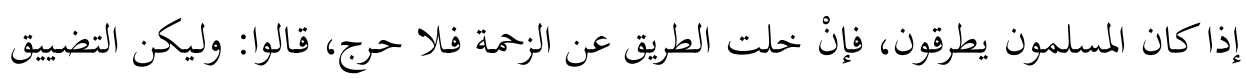

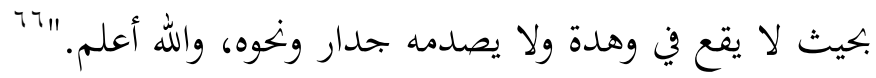

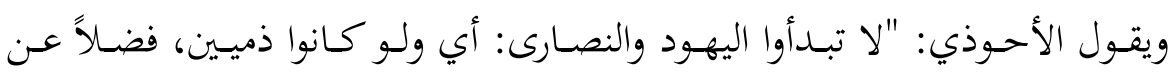

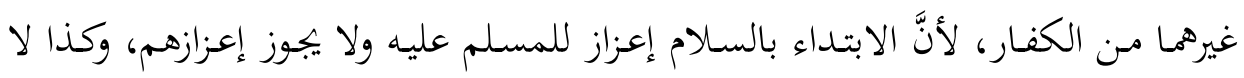

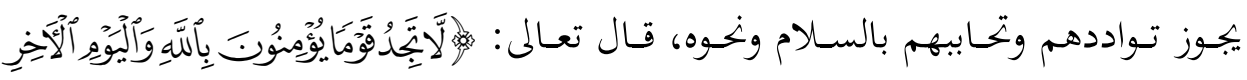

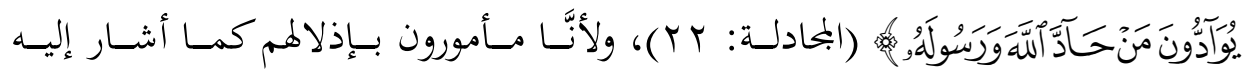

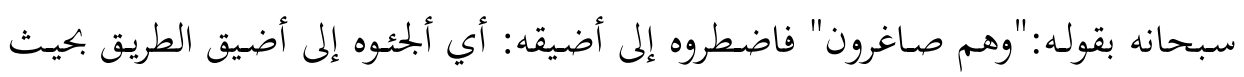

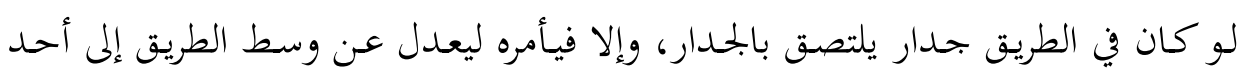

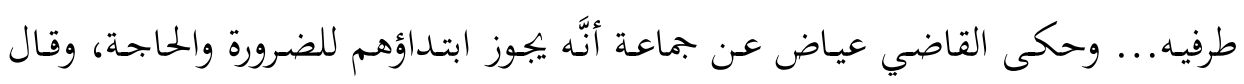

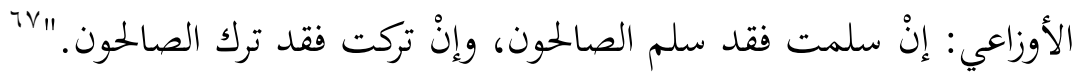

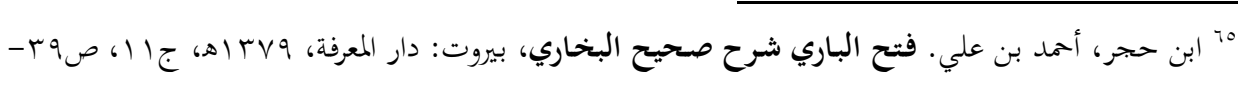
. .

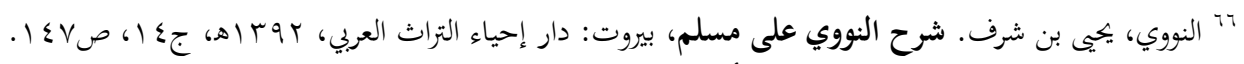

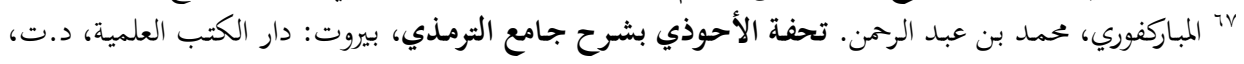


ويقول الصنعاني:"ويف الحلديث دليل على إلحائهم إلى مضيق الطرق إذا اشتركوا هـم

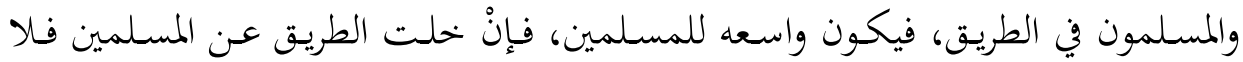

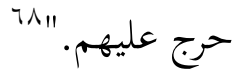

ويقول الشوكاني: "فيه تحيم ابتداء اليهود والنصارى بالسلام، وقد حكاه النووي عن

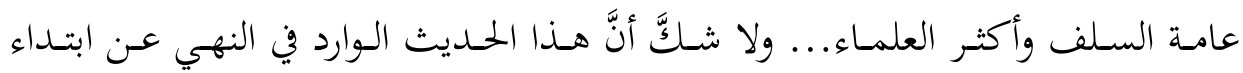

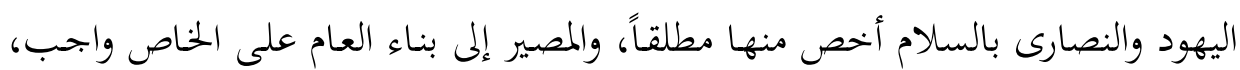

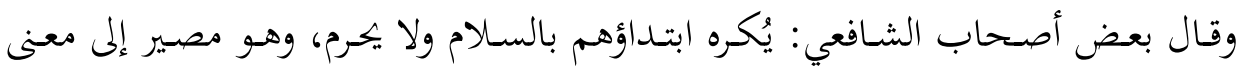

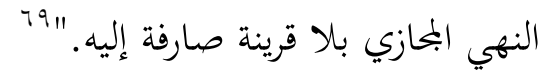

وقـــ اتفقـت المـذاهب الفقهيـة الأربعـة على عـدم جـواز إلقـاء السـلام على أهـل

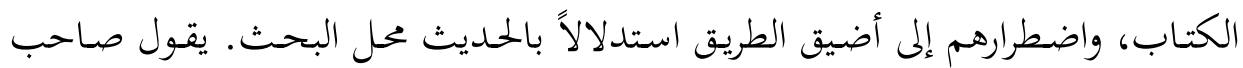

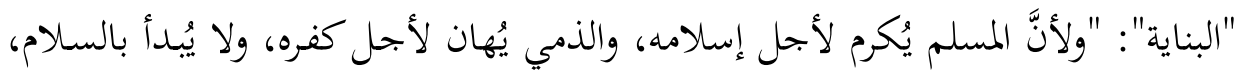
ويُلحق إلى أضيق الطريق." ل

ويقول صاحب "هاية المحتاج": "ويلجأ وجوباً عند ازدحام المسلمين بطريق إلى أضيق

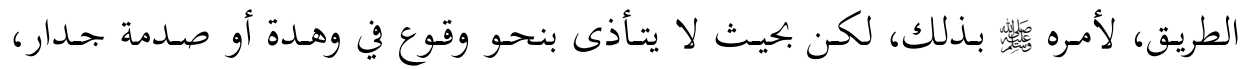

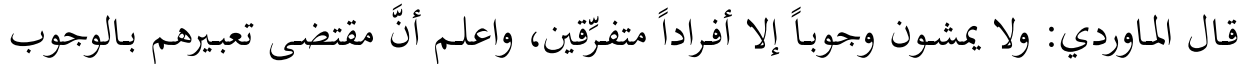

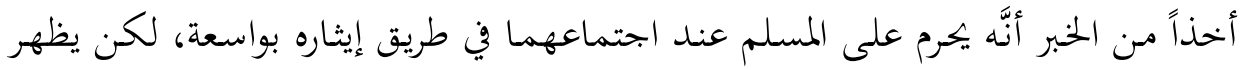

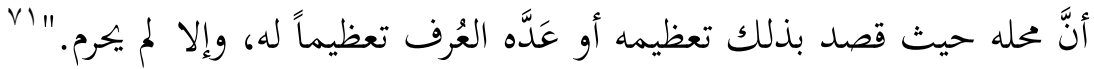
ويقول القرايف: "يمنعون من جادة الطريق، ويضطرون إلى المضيق إذا لم يكن الطريق

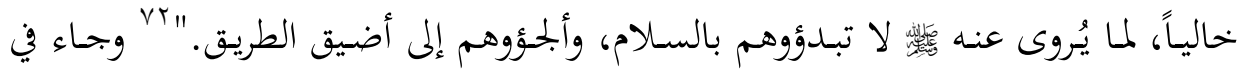

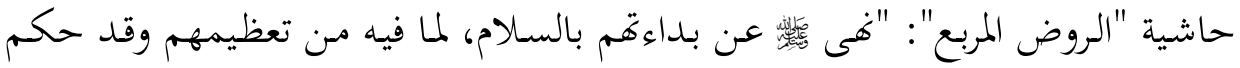

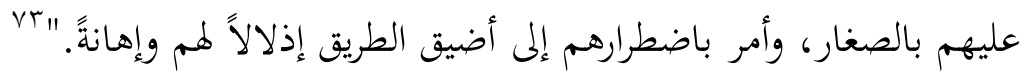

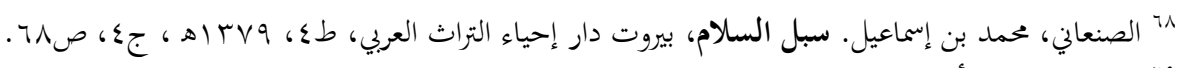

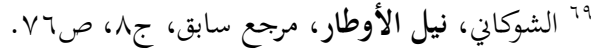

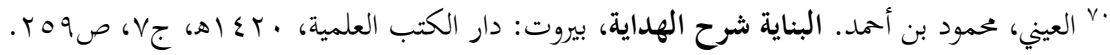

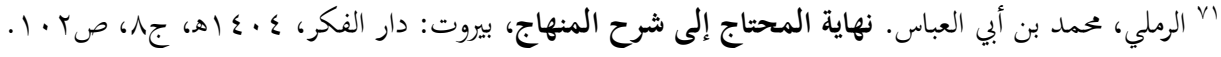

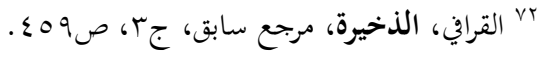

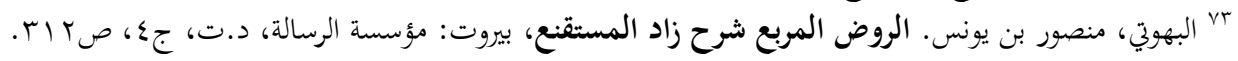




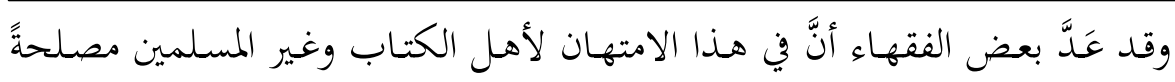

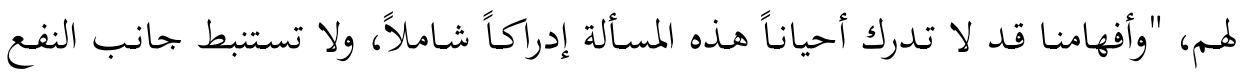

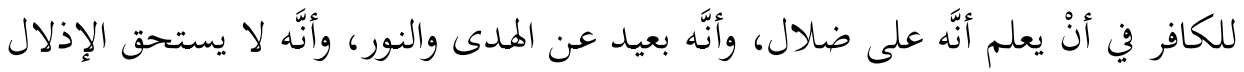

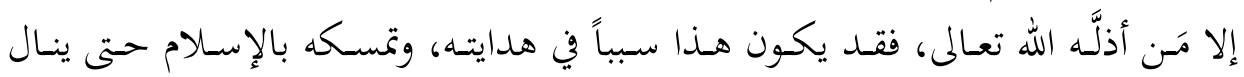

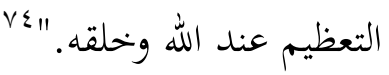

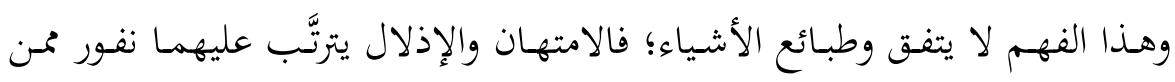

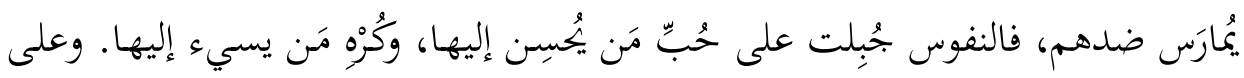

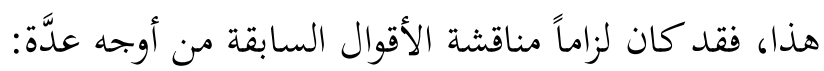

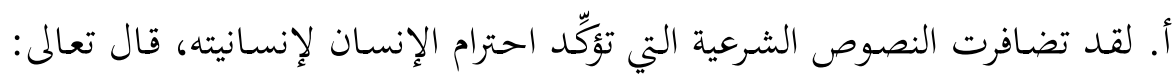

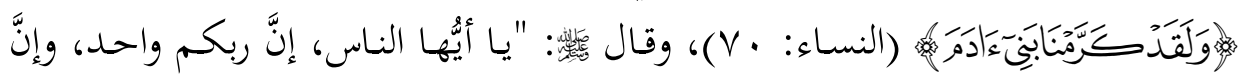

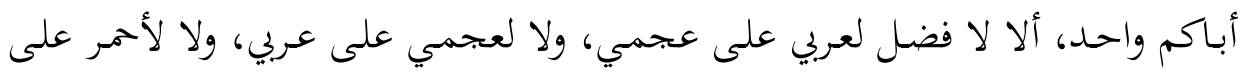

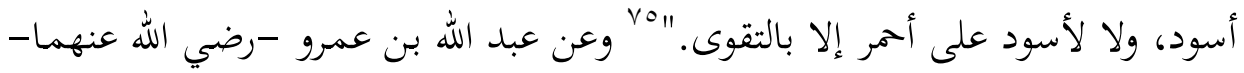

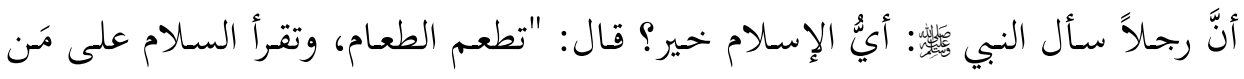

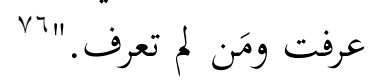

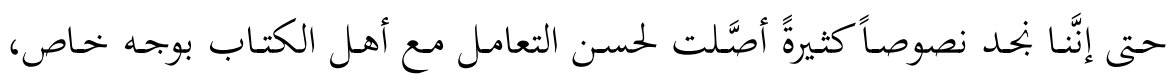

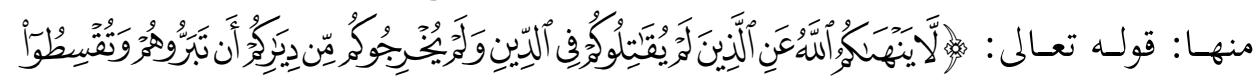

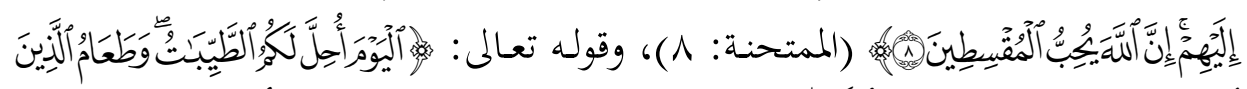

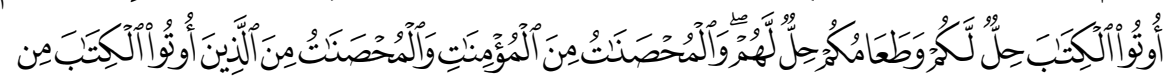

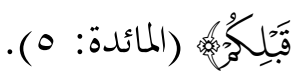

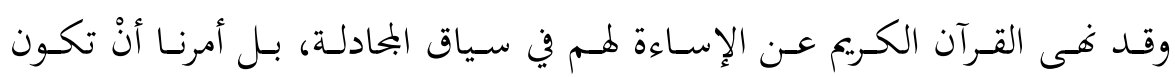

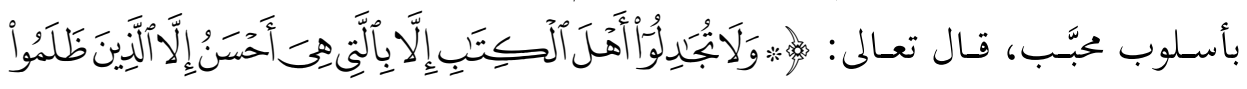
§ إضل، يونس عبد الرب. نظرة شرعية في معاملة أهل الكتاب في المرور على الطريق، موقع جامعة الإمعان

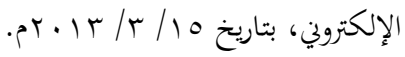

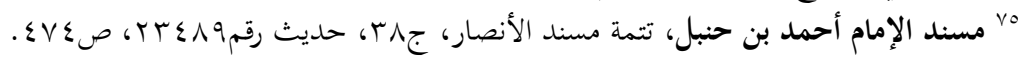

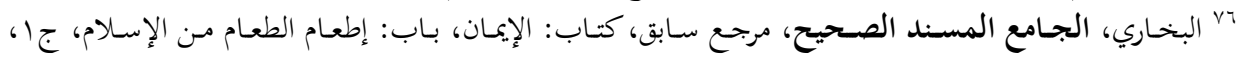

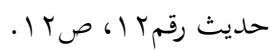




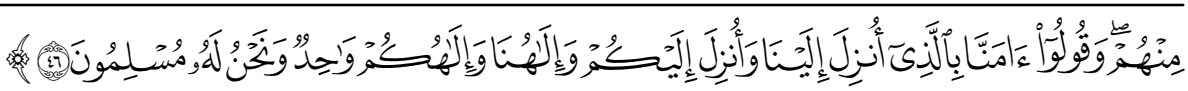

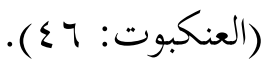

وقال رسول الله

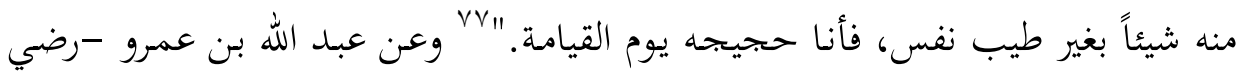

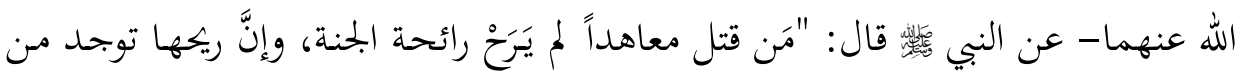

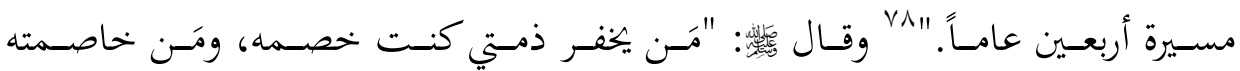

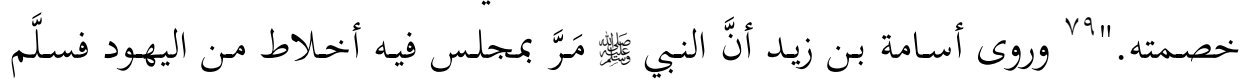
عليهـم. "

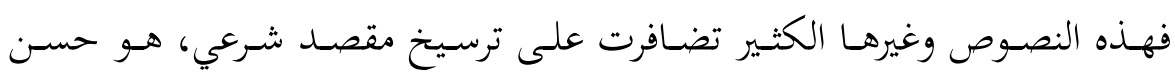

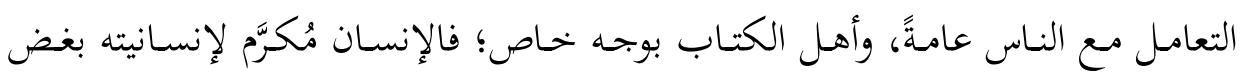

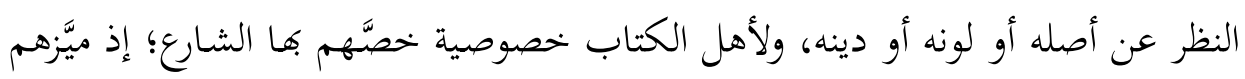

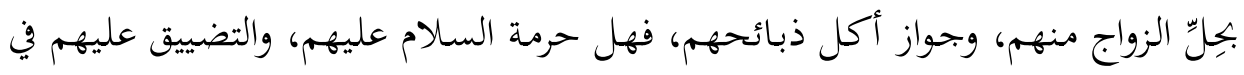

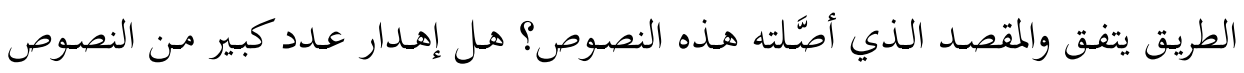

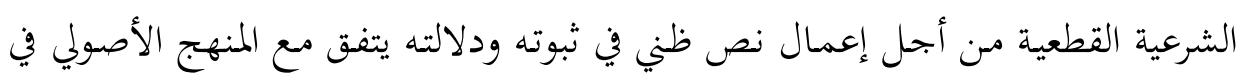

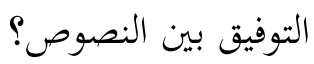

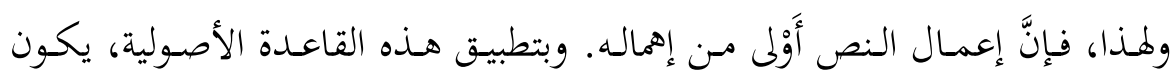

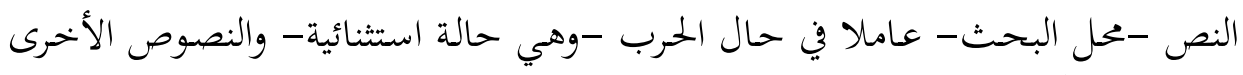
هي التي تشكّل القاعدة العامة.

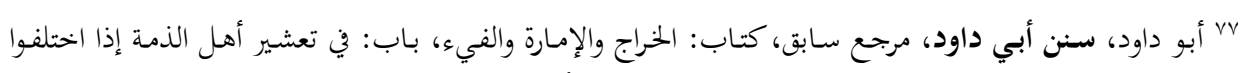

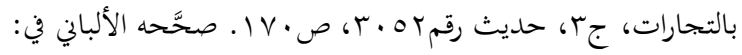

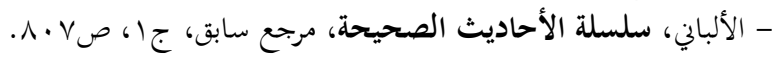

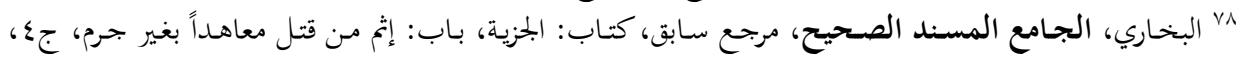

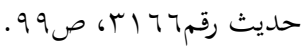

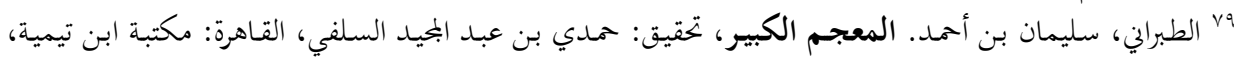

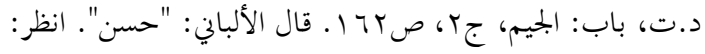

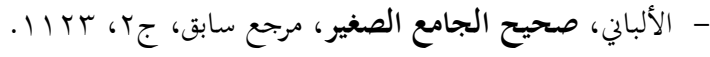

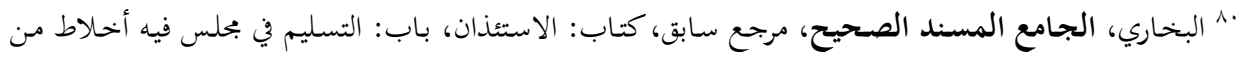

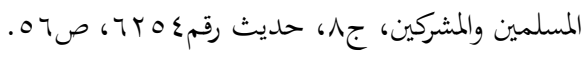




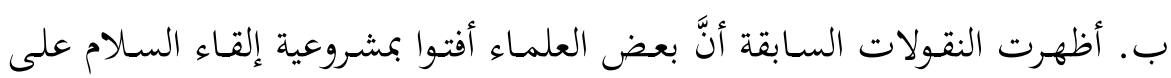

أهل الكتاب.

فهذا الرأي الفقهي -على الرغم مـن وجـود النص النـاهي عن ذلك، الـداعي إلى

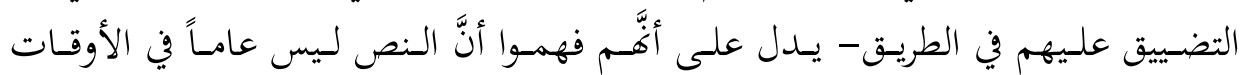

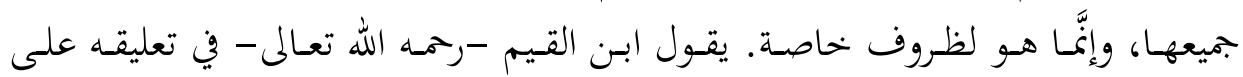

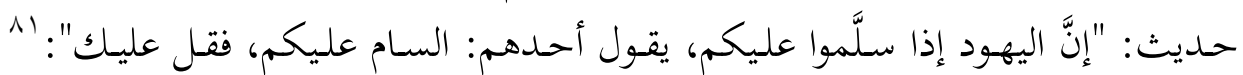

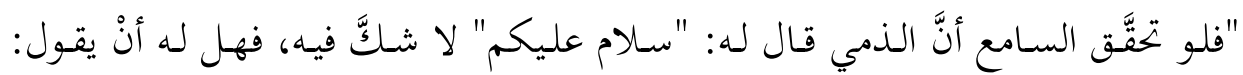

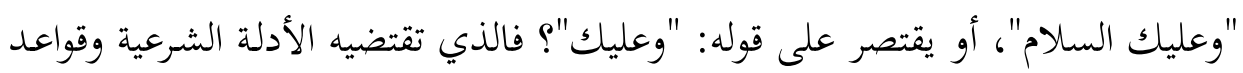

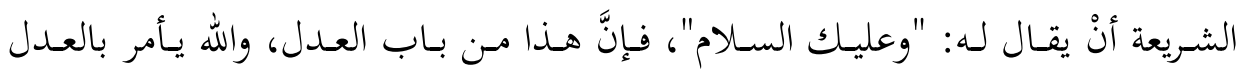

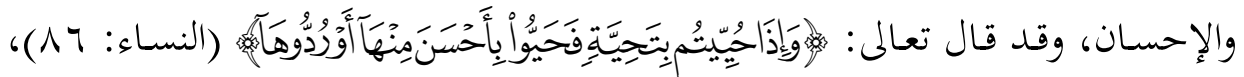

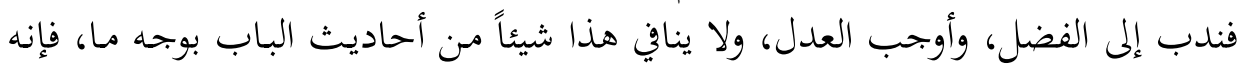

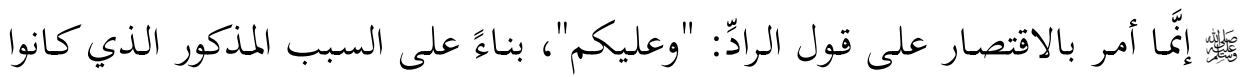

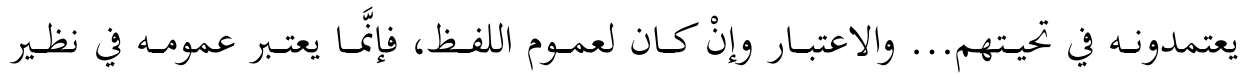
المذكور لا فيما يخالفه."

فهذا ابن القيم قصر إعمال النص على الحالة التي كان عليها اليهود، فإذا زالت العلة

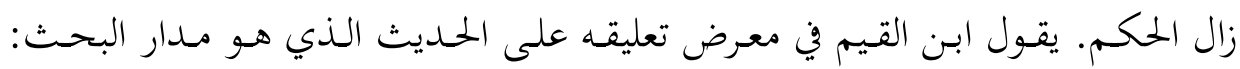

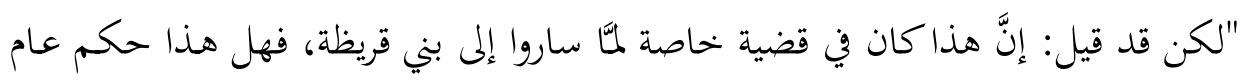

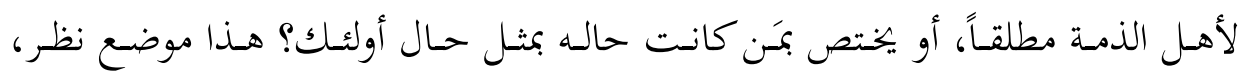

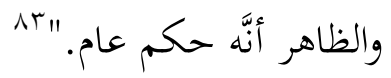

إذن، فقد رأى بعض العلماء أنَّ هذا هو نص خحاص لا عام، وأنَّ إعماله يكون في الظروف المشابهة للظروف التي قيل فيها، وليس على إطلاقه.

1^ مسلم، المسند الصحيح المختصر، مرجع سابق، كتاب: السلام، باب: النهي عن ابتداء أهل الكتاب بالسلام،

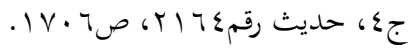
Ar

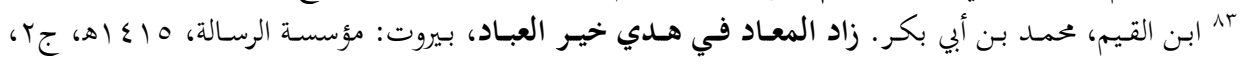


ت. أوضحت الظروف المحتفة بالنص الباعثَ على قوله؛ فقد روى البخاري ومسلم

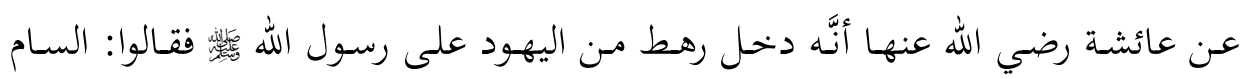
عليكم، قالت عائشة: فقهمتها، فقلت: وعليكم السام واللعنة، قالت: فقال رسول الله

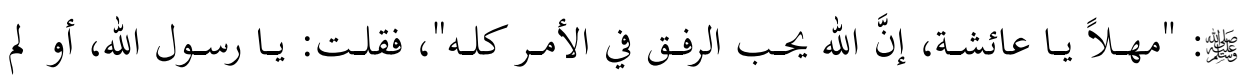

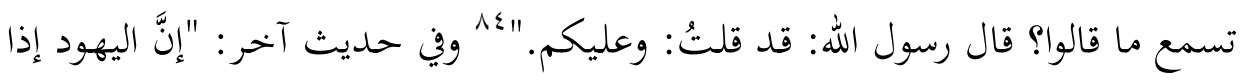
سلَّموا عليكم، يقول أحدهم: السام عليكم، فقل: عليك." فهذان النصان يرسمان صورة

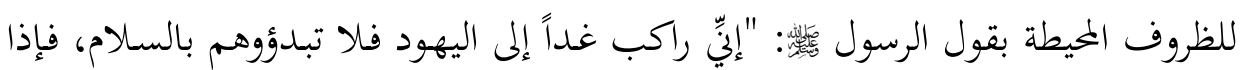

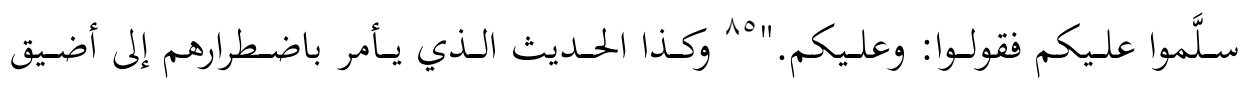
الطريق.

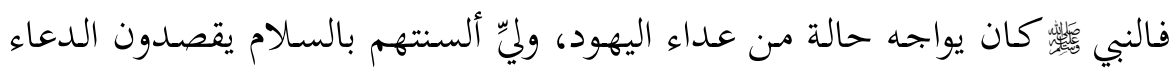

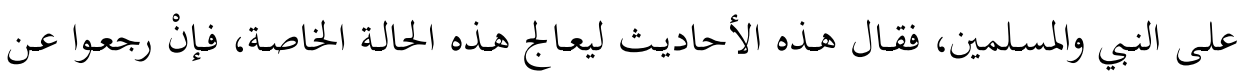

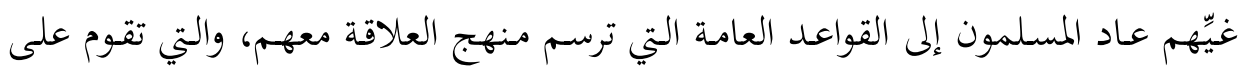
البر والعدل والإحسان.

ث. ثبـت أنَّ النبي واضَح صريح أنَّ النبي بالسلام أصبح يرد عليهم بكلمة "عليكم"، وهى عن بدئهم بالسلام. ج. أباح الشارع التهادي مع غير المسلمين، بالرغم مـن أنَّأحد مقاصد الهدية هو

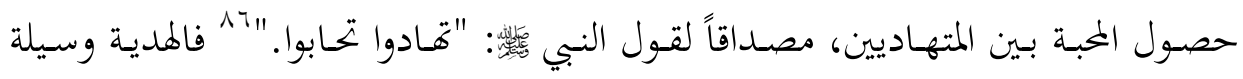

ع^ البخاري، الجـامع المسـند الصسحيح، مرجع سابق، كتاب: الأدب، باب: الرفق في الأمر كله، جه، حديث

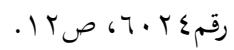

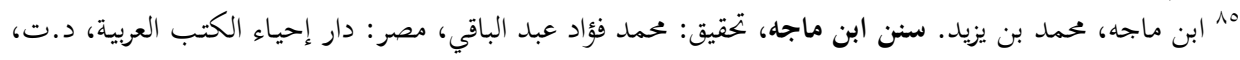

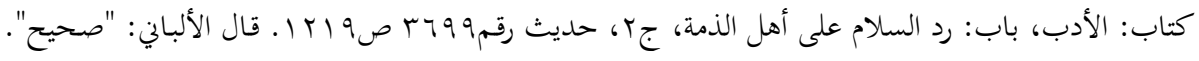
انظر:

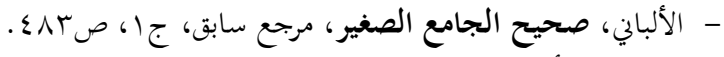

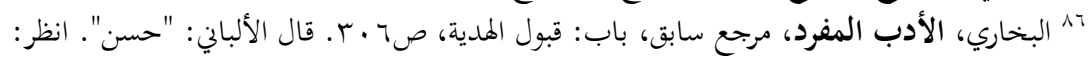

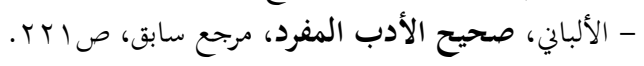




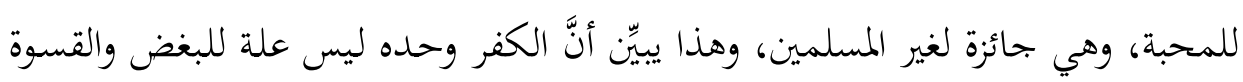

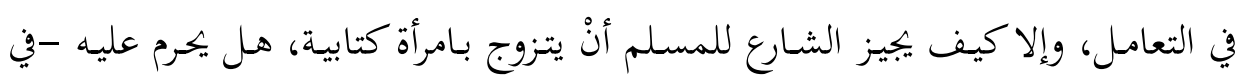

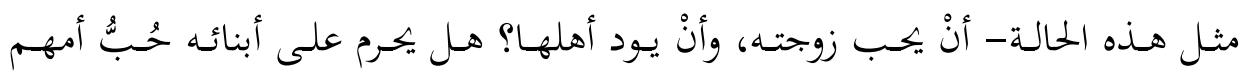

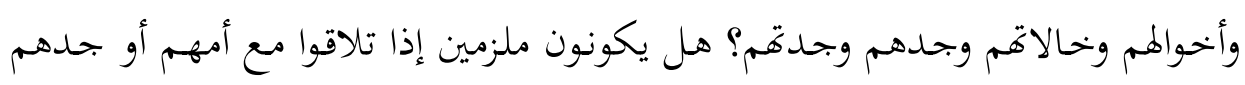

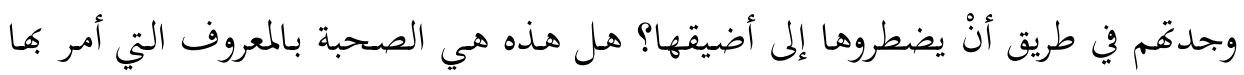

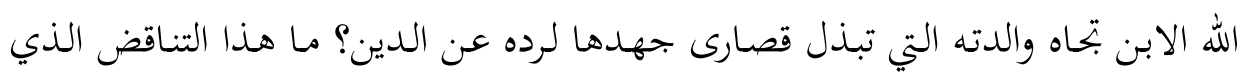

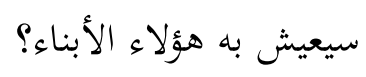

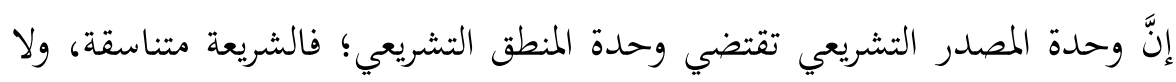

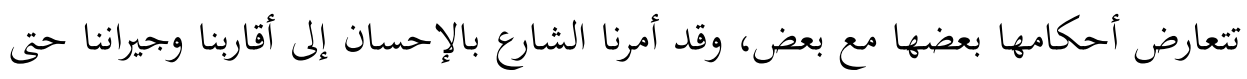

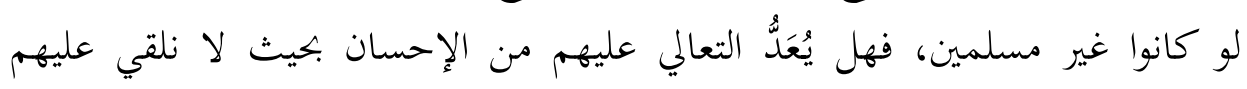

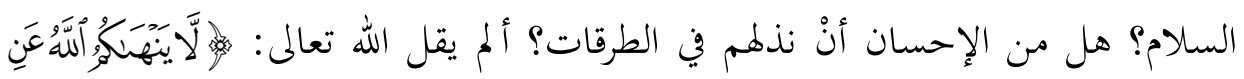

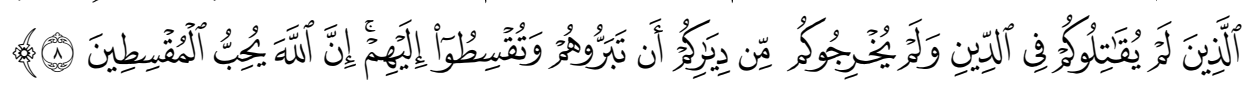
(الممتحنة: م) والكثير من النصوص التي أمرت بحسن التعامل معهم؟

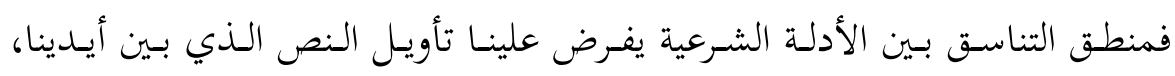

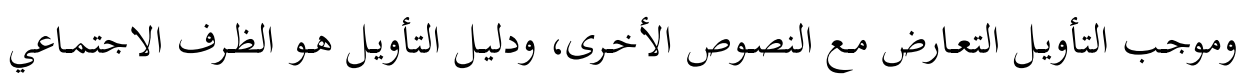

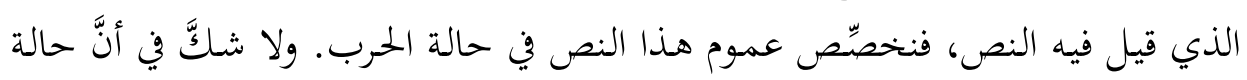

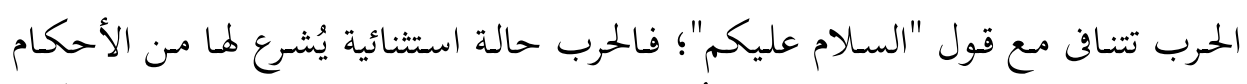

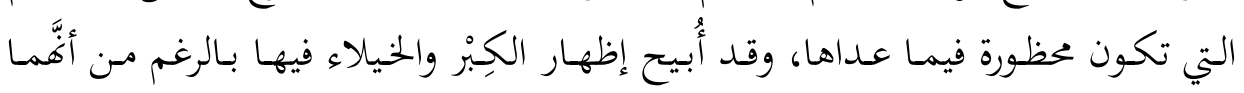

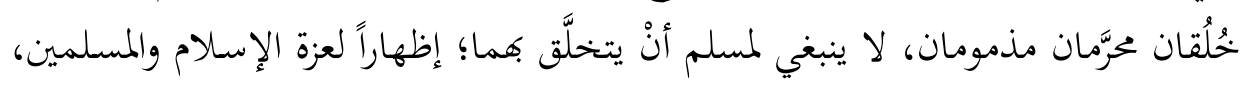

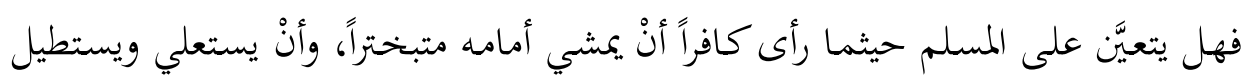

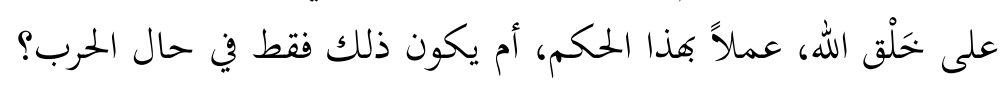
والواقع أنَّ التضييق على الناس في الطرقات حرام؛ إذ قال النبي فئس

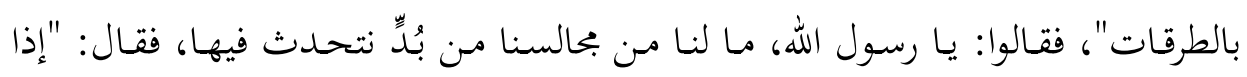

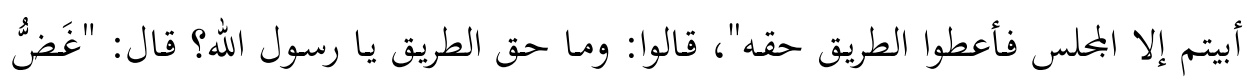




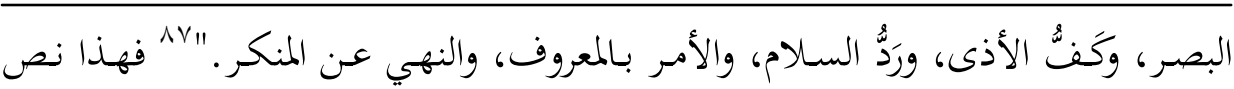

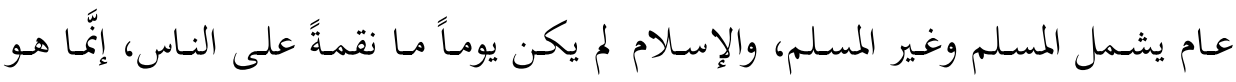

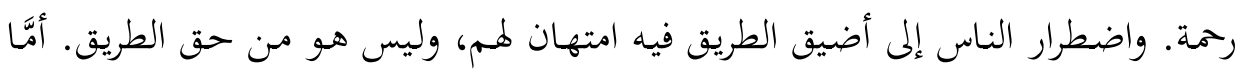

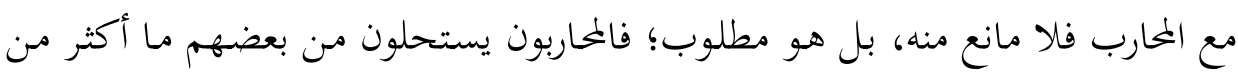

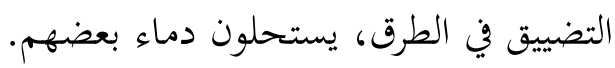

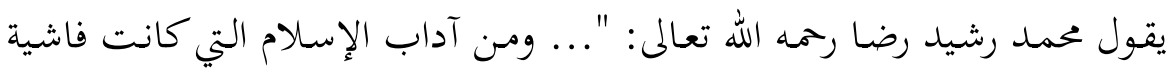

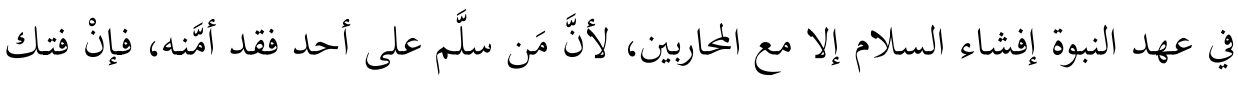

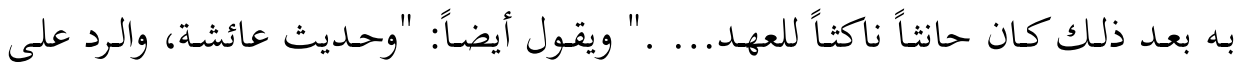

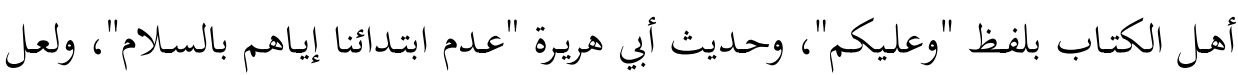

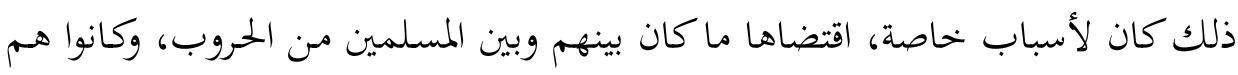

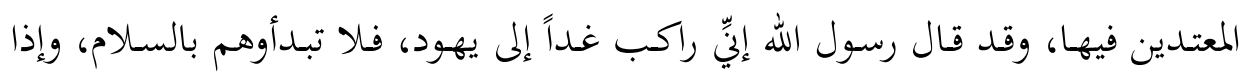

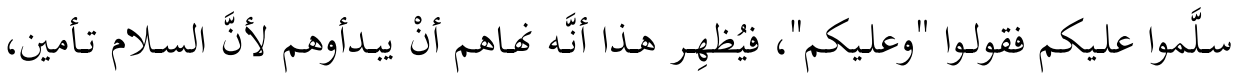

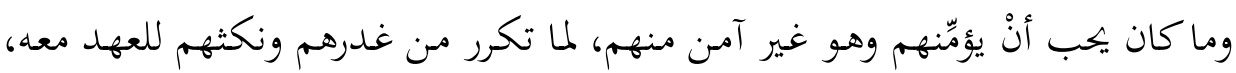

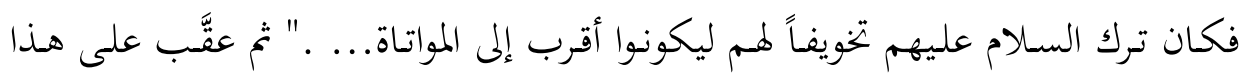

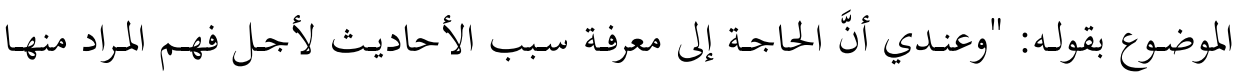

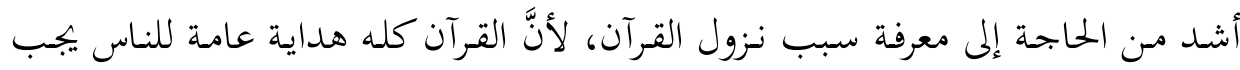

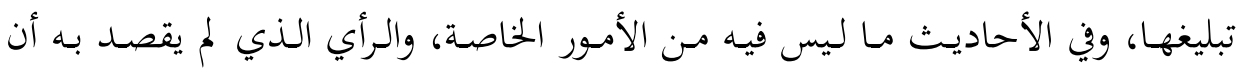

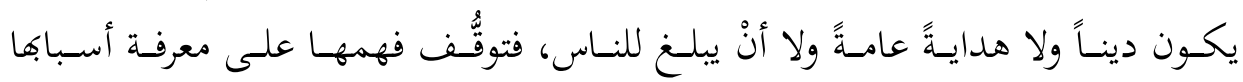

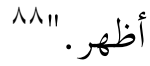

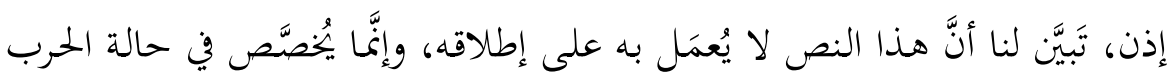

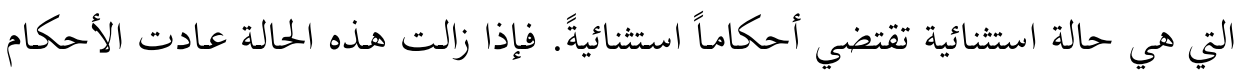

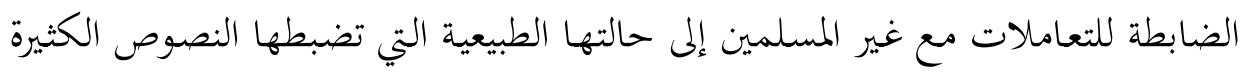

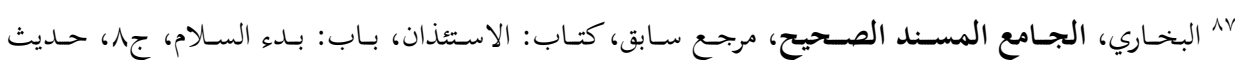

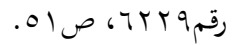

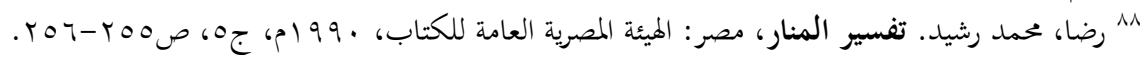




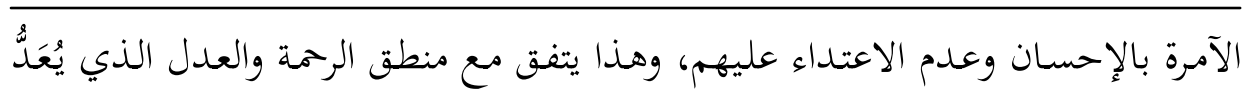
من القيم العليا الحاكمة على التشريعات الجزئية.

\section{7. القتال في التصور الإسلامي:}

عن ابن إسحاق، حدثني يهيى بن عروة عن أبيه، عن عبد الله بن عمرو، قال: قلت:

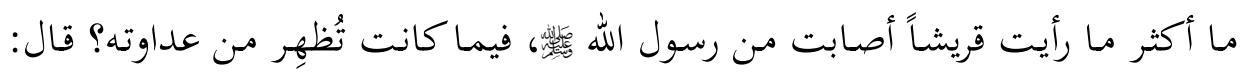

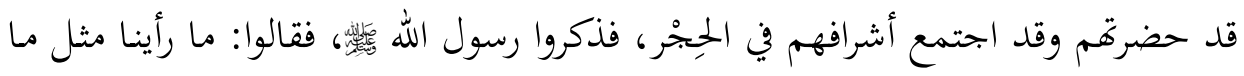

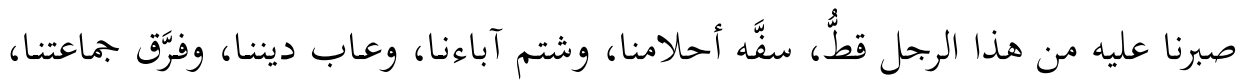

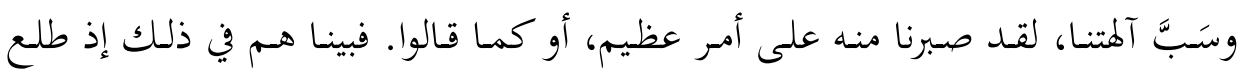

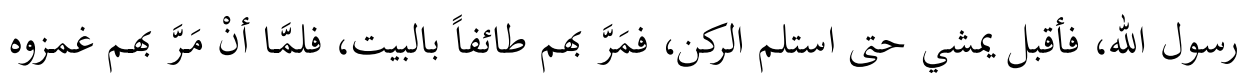

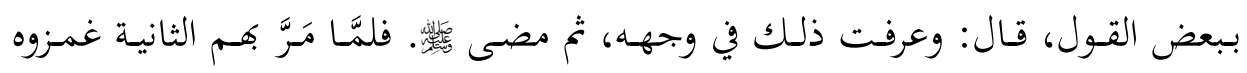

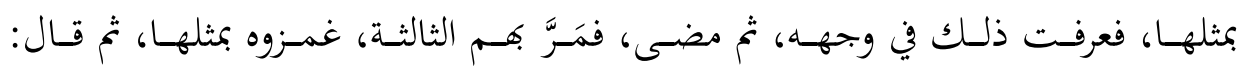

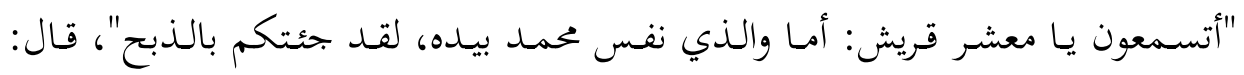

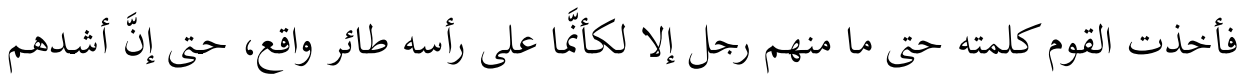
فيه وطأة قبل ذلك يتوقاه بأحسن ما يجيب من القول، حتى إنَّه ليقول: انصرف راشت راشداً، فوالله ما كنت جهولاً، فانصرف رسول الله حتى إذاكان من الغد اجتمعوا في الحجر وأنا معهم، فقال بعضهمم لبعض: ذكرتم ما بلغ منكم، وما بلغكم عنها، حتى إذا بادأكم بما

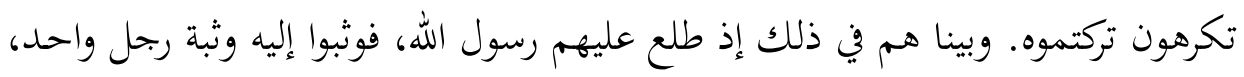
وأحاطوا به، يقولون له: أنت الذي تقول كذا وكذا، لماكان يبلغهم عنه من عيب في آلهتهم

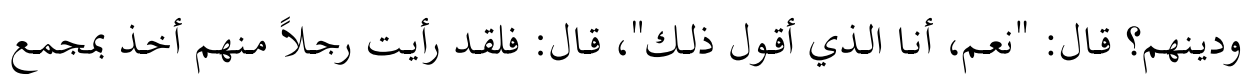

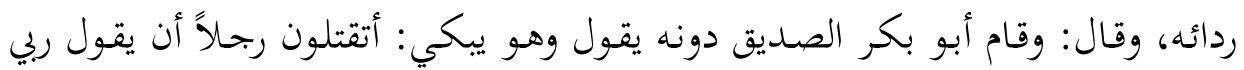

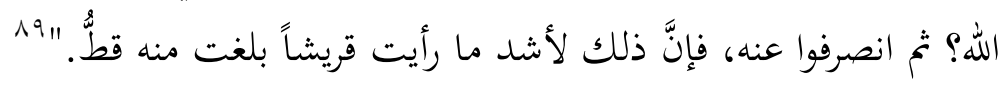

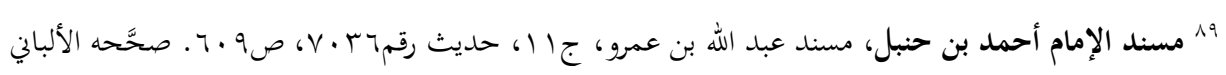




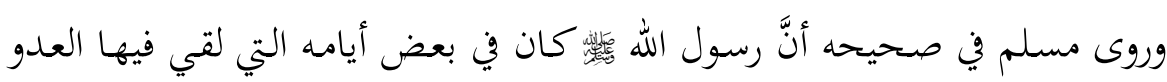

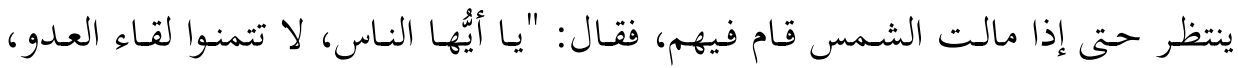

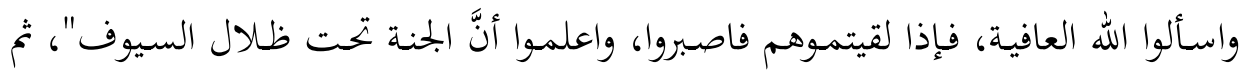
قام النبي

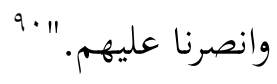

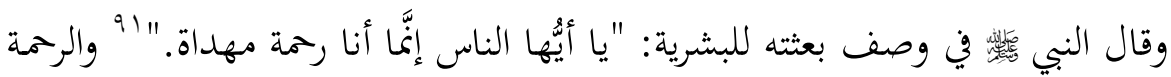

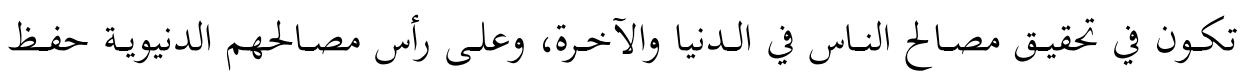

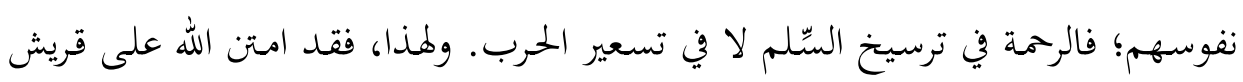

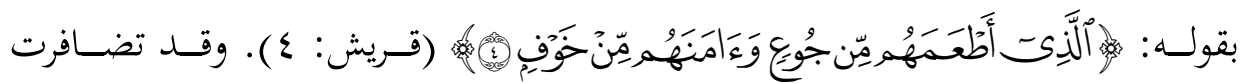

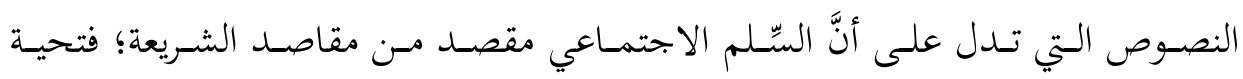

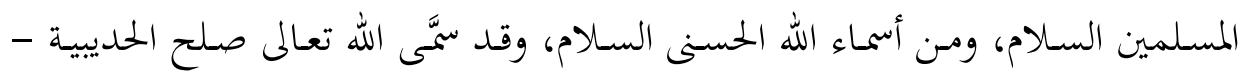
الذي أرسى حالة السِّلم مع قريش - بـالفتح المبـين. فالوسط الذي ينتشر فيه الإسـلام ويتملَّد هو السِّلم لا الحرب، وقد دخل في الإسلام بعد صلح الحديبية أضعاف ما دخلوه قبل ذلك.

فمما لا شـكَّ فيه أنَّ طريقـة إيمان النـاس بـالفكر هي الحوار والإقناع لا القتـل، وأنَّ القوة والقمع والبطش هي طريقة السيطرة على الأجساد لا القلوب والعقول، وأنَّ إجبار

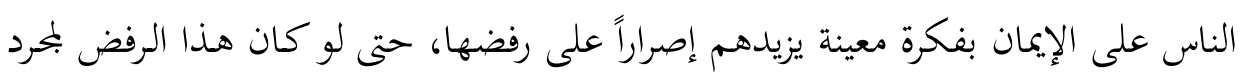

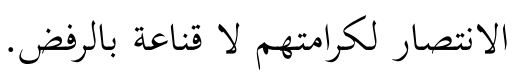

ولكن، لـمَّا قرأت بعض الاتحاهـات الإسـلامية هـذين النصـين بصـورة ظاهريـة فتــ

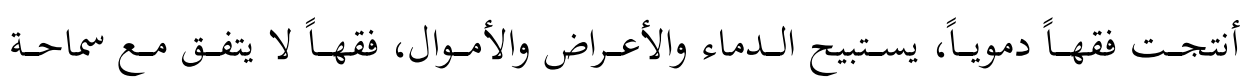
•" مسلم، المسند الصحيح المختصر، مرجع سابق، كتاب: الجهاد والسير، باب: كراهة تمني لقاء العدو، جr،

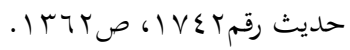

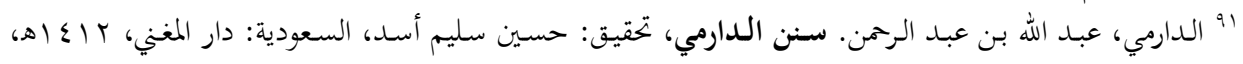

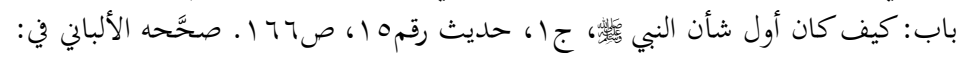

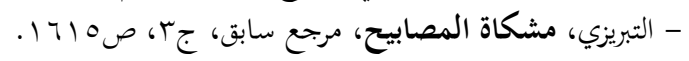




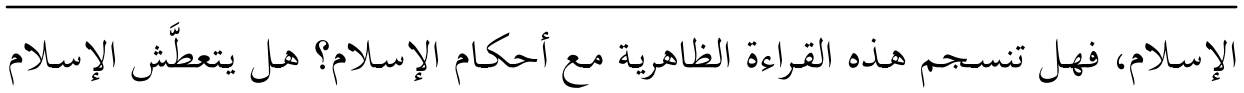

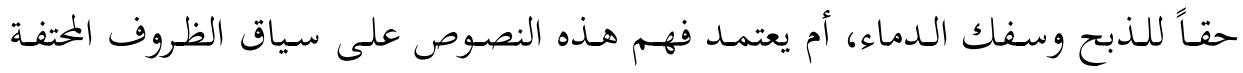

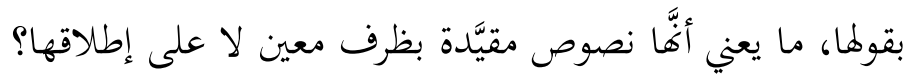
بدايةً، سناقش فحوى الحديث الأول "لقد جئتكم بالذبح":

لا يمكن فهم هذا الحمديث فهماً صحيحاً إلا بسوق بعض النصوص ذات الصلة

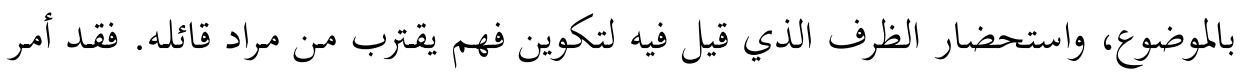

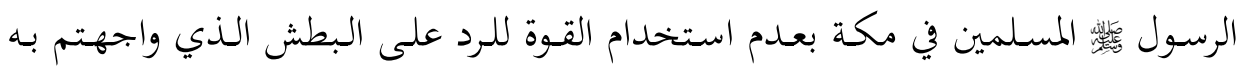

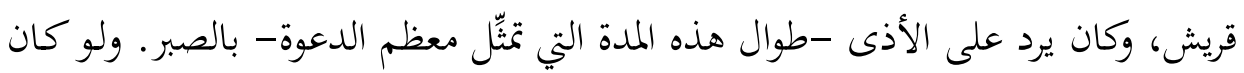

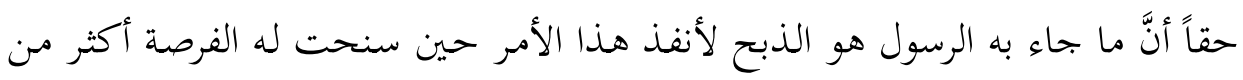

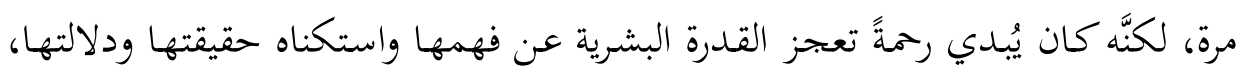
ومن ذلك:

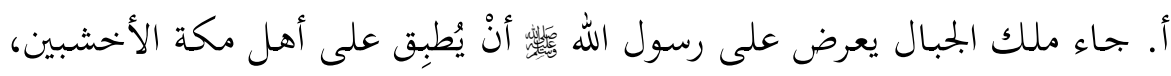

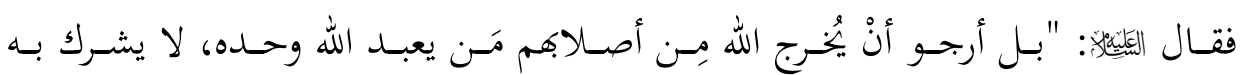
شيئll

ب. عن أبي هريرة قال: بعثث النبي خيلاً قِبل بحد، فجاءت برجل فيل من بني حنيفة

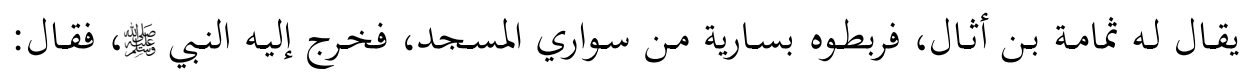

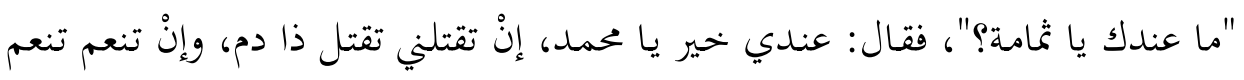

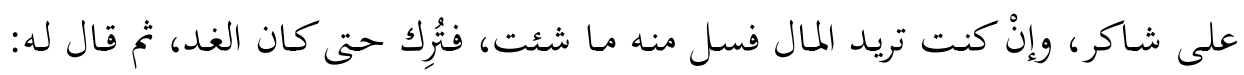

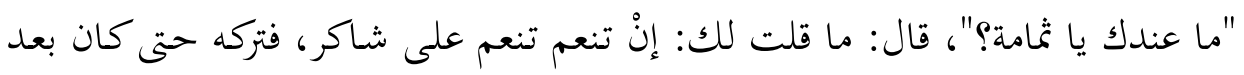

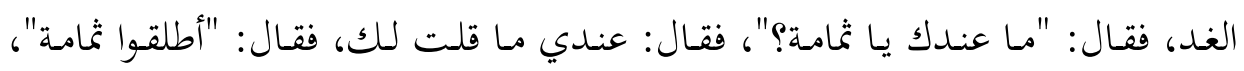

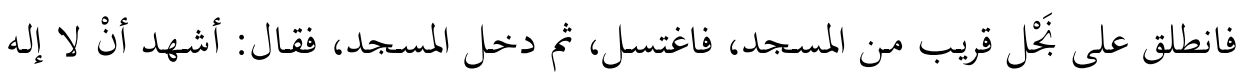

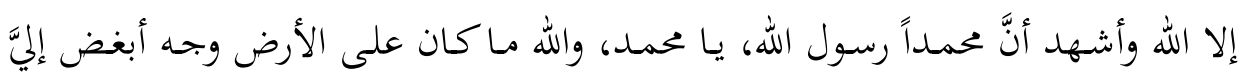
ro البخاري، الجامع المسند الصحيح، مرتع سابق، كتاب: بدء الملقى، باب: إذا قال أحدكم آمين، ج؛، حديث

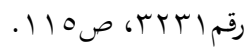




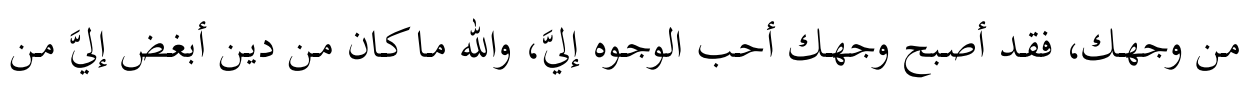

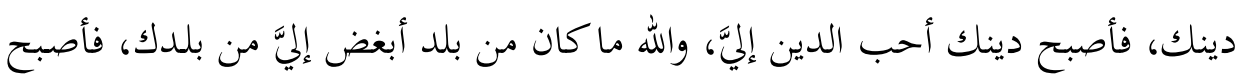

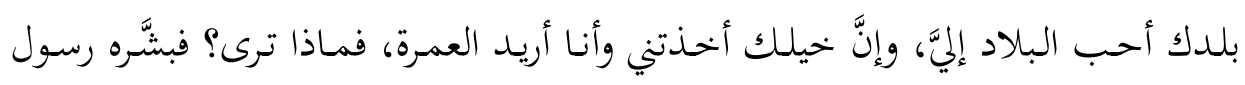

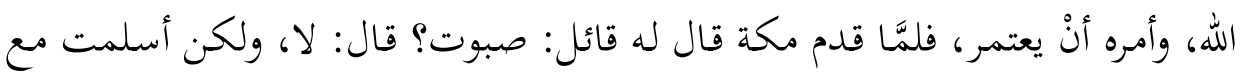
محمد رسول الله $9{ }^{\prime \prime \prime}$.

فهذا النص يبيِّن سماحة النبي

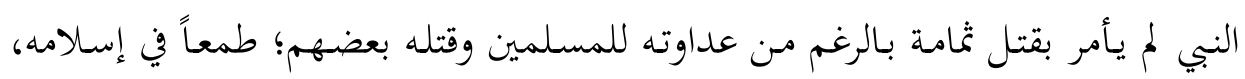

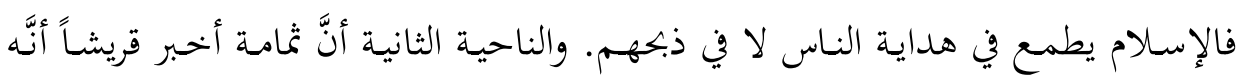

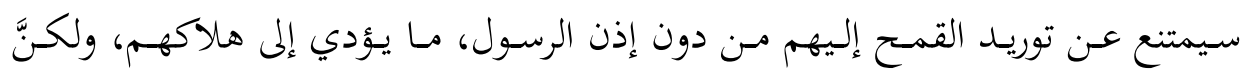
الرسول لم يأذن له بذلك، ولو كان هدف الرسول ذبح قريش ما تردَّد في تجويعهم.

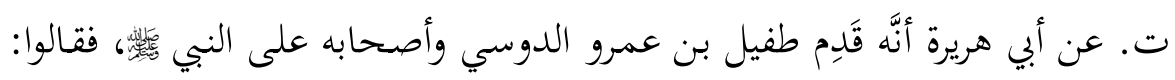

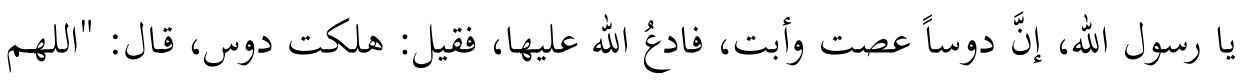

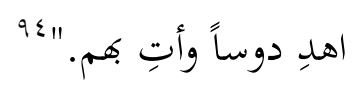

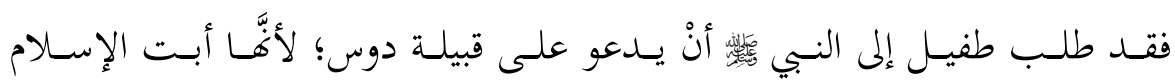

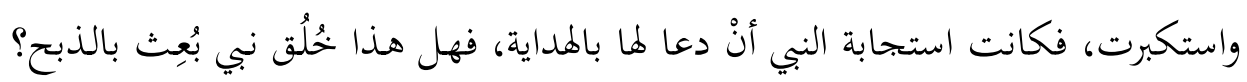

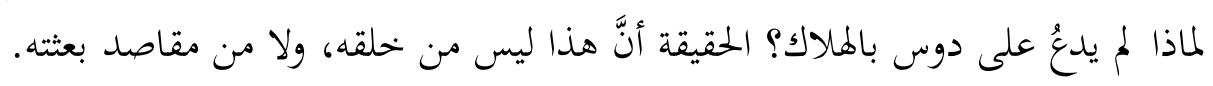

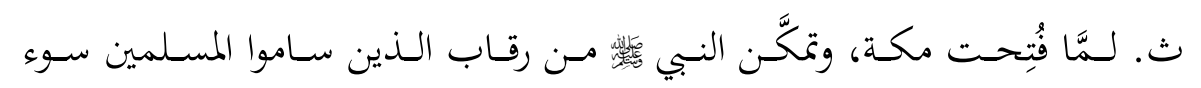

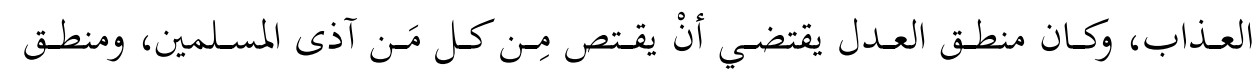

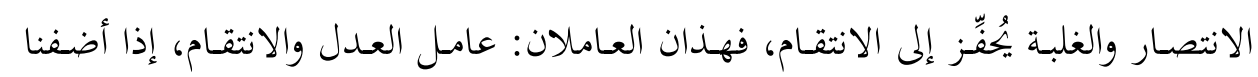

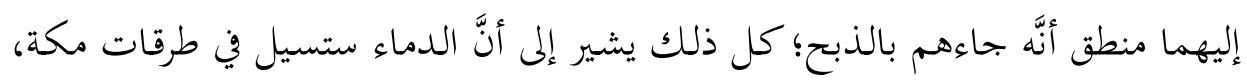
فانظر كيف تعامل معهم.

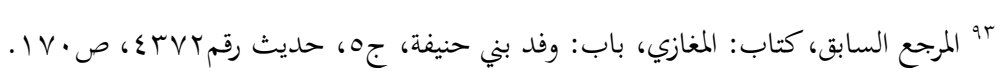

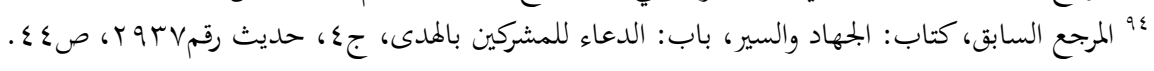




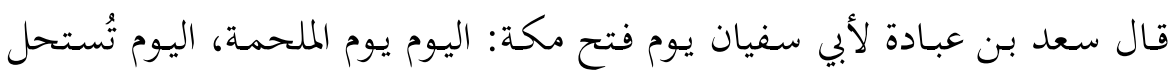

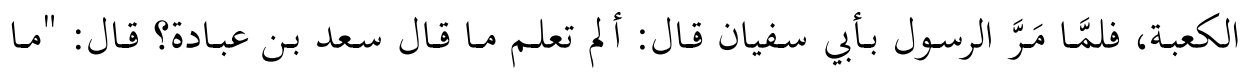

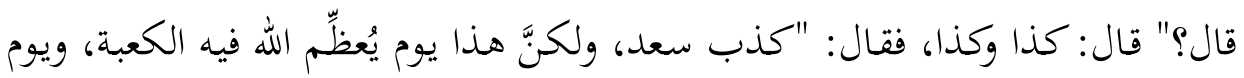

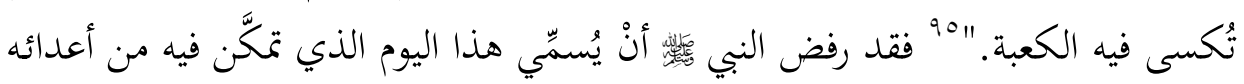
يوم الملحمة، وأخذ الراية من سعد وأعطاها ولدها.

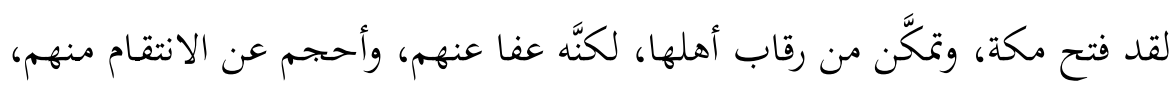

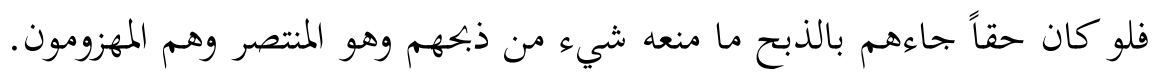

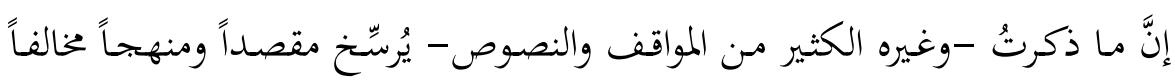

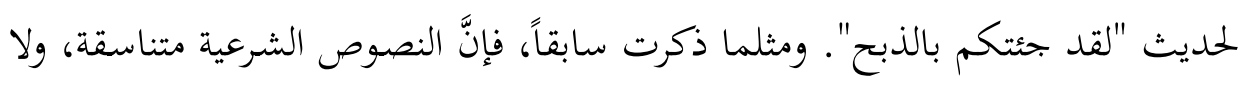

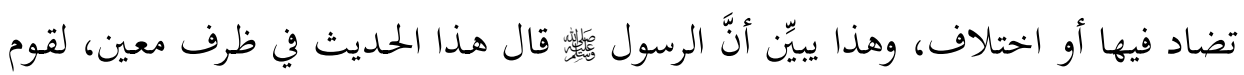

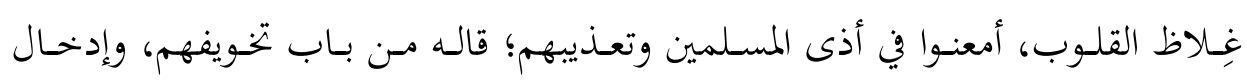

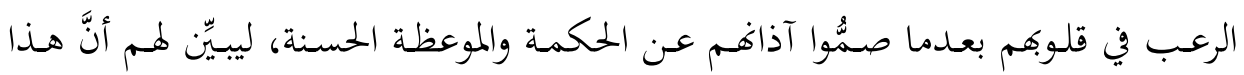

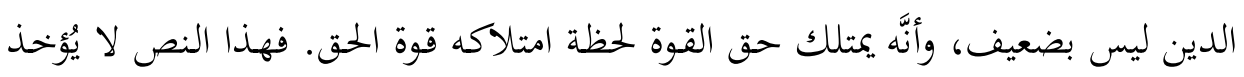

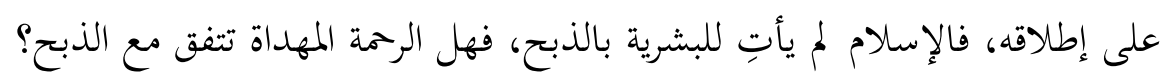
وأمَّا بالنسبة إلى النص الثاني "الجنة تحت ظلال السيوف" فيتضح من الظروف المتحفة

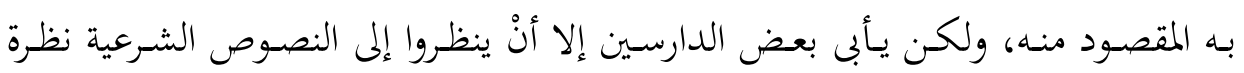

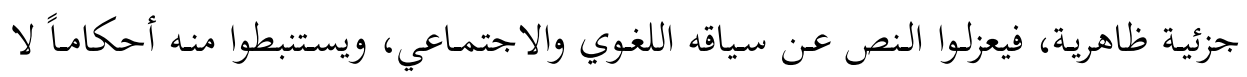

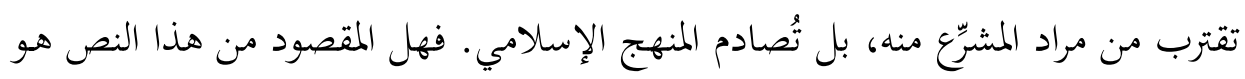

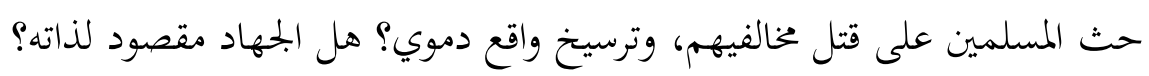

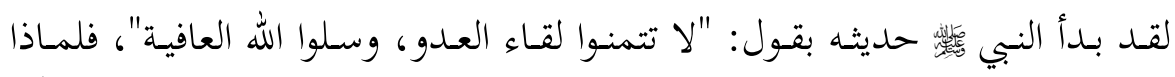

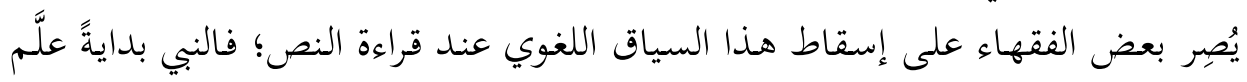

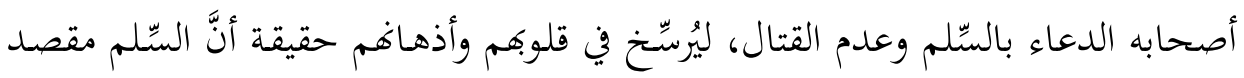

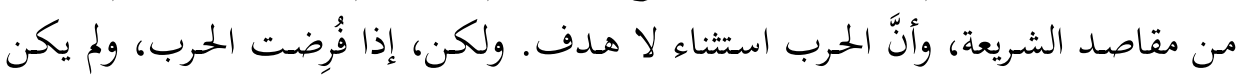

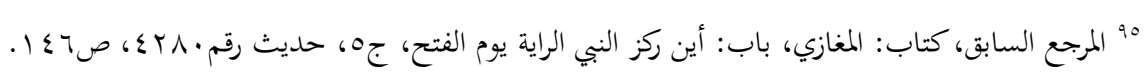




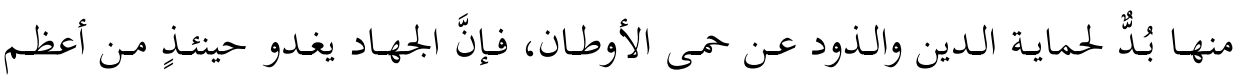

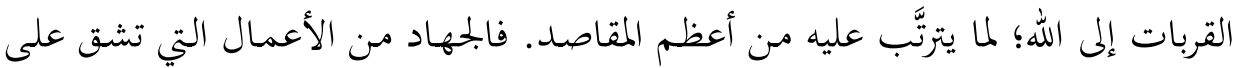

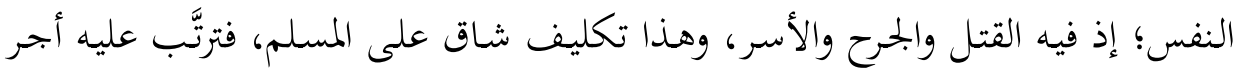

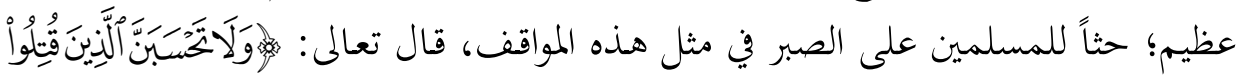

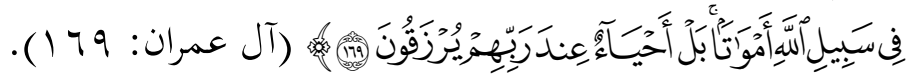
فهذا الحميث يوافق معنى الآية الكريمة من باب التحريض على القتال حينما يصبح

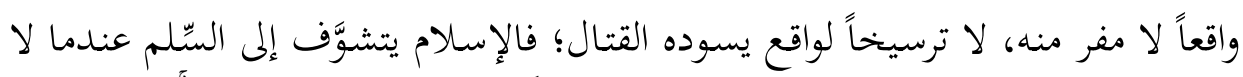

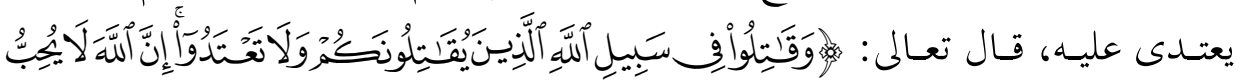

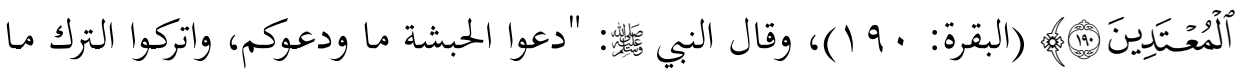
تركوكم." "94.

ومسن هنـا، فإنَّ المعنى الذي يقصـده النص مـن الحـث على الثبـات في أثنـاء القتـال

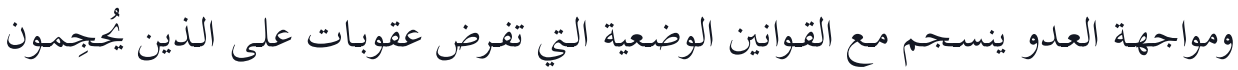

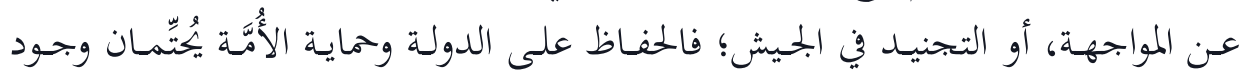
جيش قوي يبذل الغالي والنفيس من أجل الحفاظ على المصالح العليا للدولة.

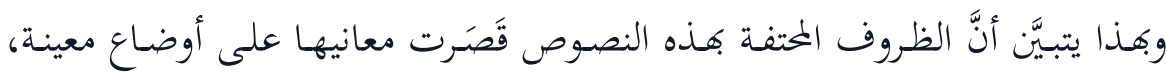

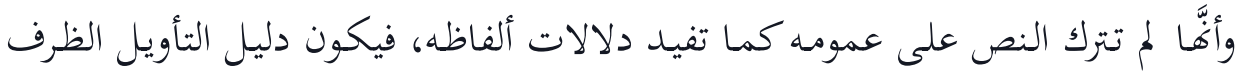
الذي قيل فيه النص.

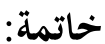

برزت منذ فجر الإسلام إشكالية النظرة الظاهرية للنصوص، ثم أخذات تتبلور مع أنح تطور الفكر الإسلامي، فغالى بعض الفقهاء فيها حتى نتج فقه يجافي المنطق أحياناً. وفي المقابل، فقد ظهرت مدرسة أخرى حاولت النفاذ إلى أعماق النص، واستكناه روحه المهيمنة عليه، واستثمار الظروف المحتفة بـه عند استنطاقه، فلم تقف عند ظواهر بو أبو داود، سنن أبي داود، مرجع سابق، كتاب: الملاحم، باب: في النهي عن كتييج الترك والحبشة، جع، حديث

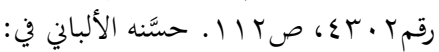

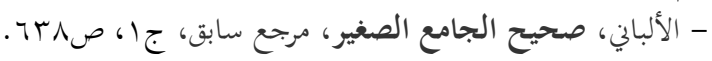




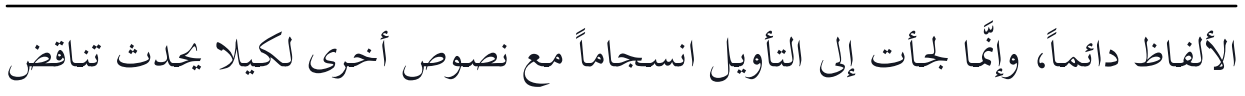

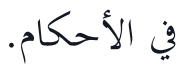

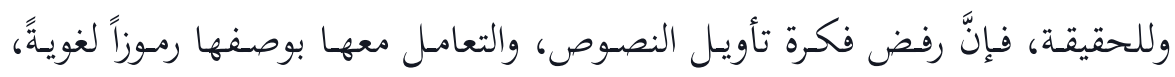

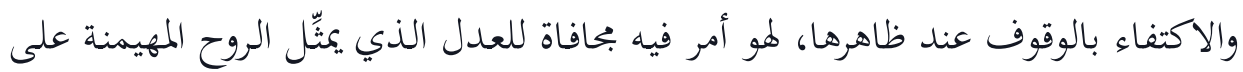

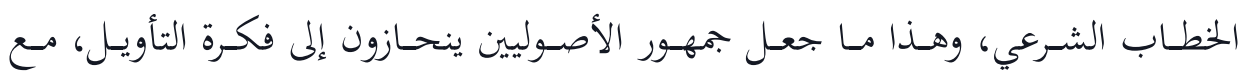
الاختلاف أحياناً في مسألة التطبيق.

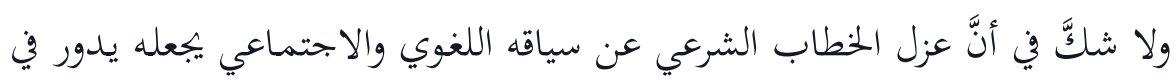

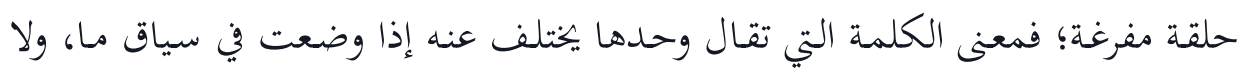

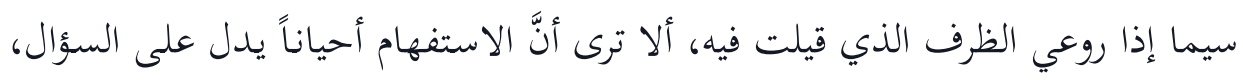
ويدل في أحايين أخرى على الاستنكار، وقد يدل على التوبيخ، وهكذا.

وأمَّا الظروف المتفة بالخطاب الشرعي فهي مكوّّن من مكوّّات فهمه، وقد تقيّّده

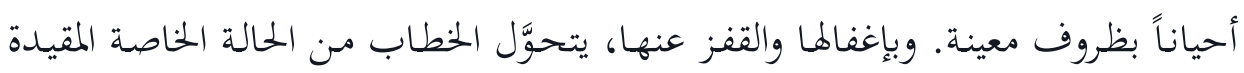

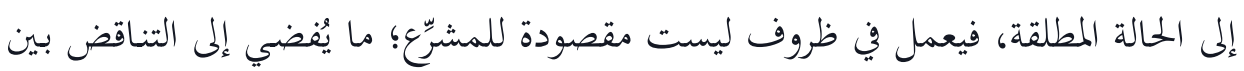

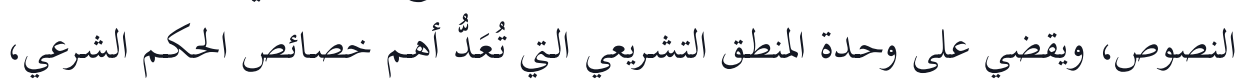

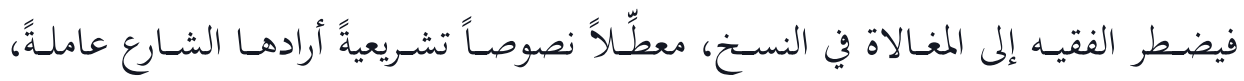

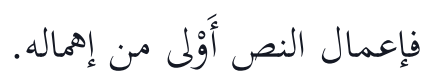

لقد قصدتُ من هذا البحث بيان أنَّ النصوص التشريعية كلها -بالرغم من صلاحية

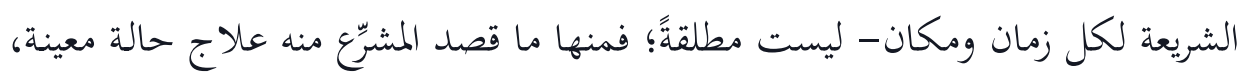

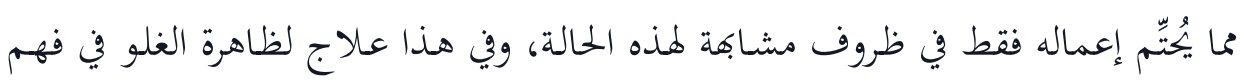

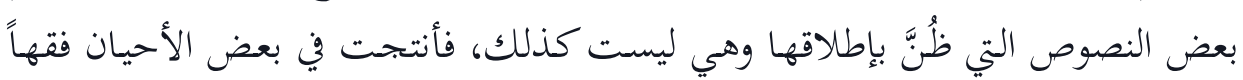

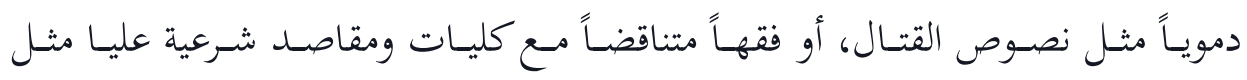

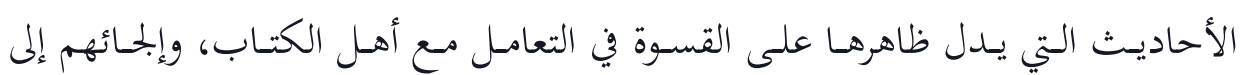
أضيق الطريق، وهكذا. 
وقد خلصتُ إلى أنَّ الخطاب الشرعي لا يمكن أنْ يُنهم - في بعض الحالات- فهماً

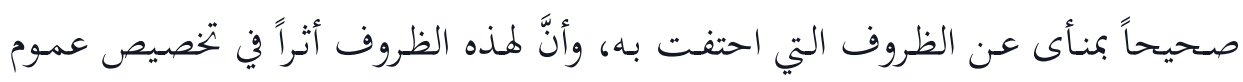

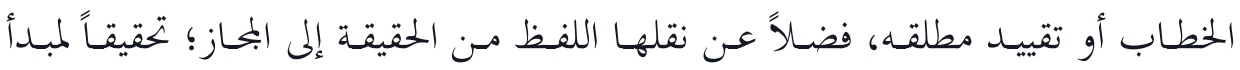
الانسجام والاتساق بين نصوص الشريعة.

ولذذا، فإِنَّ واقعنا الحالي يُحتِّم علينا أنْ نعيد قراءة كثير من النصوص، وأنْ ننقلها من دائرة الفضاء العام إلى حدود أضيق توائم مقاصد النص؛ ترشيداً للخطاب الديني، بحيث ينسجم مع قيم الإسلام ومقاصده العليا التي تضافرت نصوص الشريعة على تحقيقها. وقد أدى إغفـال الظروف المحتفة بالخطاب الشرعي إلى إنتاج فقـه ظـاهري أحياناً، وهو فقه قد يناسب بعض البيئات، بيد أنَّ الواقع تغيَّ في عصرنا، وأصبح للقيم الإنسانية

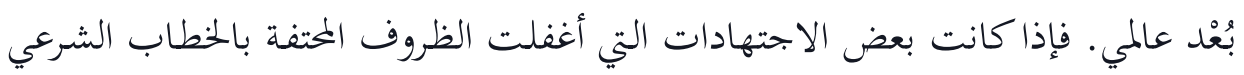

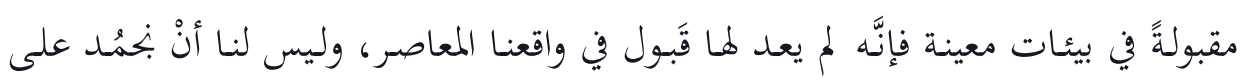

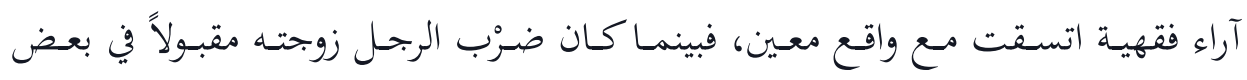

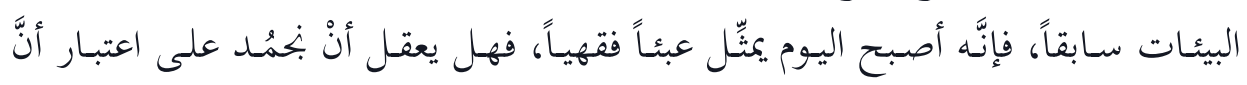

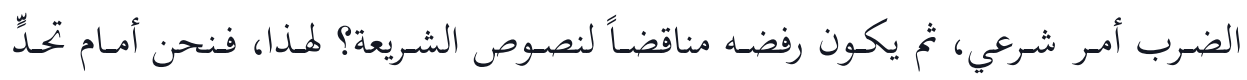

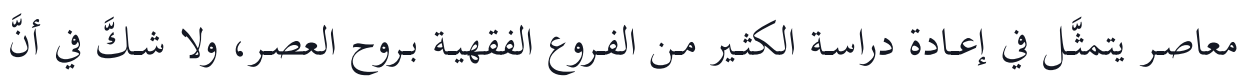
الإفادة من الظروف المحتفة بالخطاب في إعادة دراستها يُفضي إلى اجتهادات تنسجم مع بعري روح العصر. 